\title{
\#USGS
}

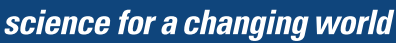

The Alaska Volcano Observatory is a cooperative program of the U.S. Geological Survey, University of Alaska Fairbanks Geophysical Institute, and the Alaska Division of Geological and Geophysical Surveys. The Alaska Volcano Observatory is funded by the U.S. Geological Survey Volcano Hazards Program and the State of Alaska.

\section{Volcanic Activity in Alaska, Kamchatka, and the Kurile Islands: Summary of Events and Response of the Alaska Volcano Observatory}

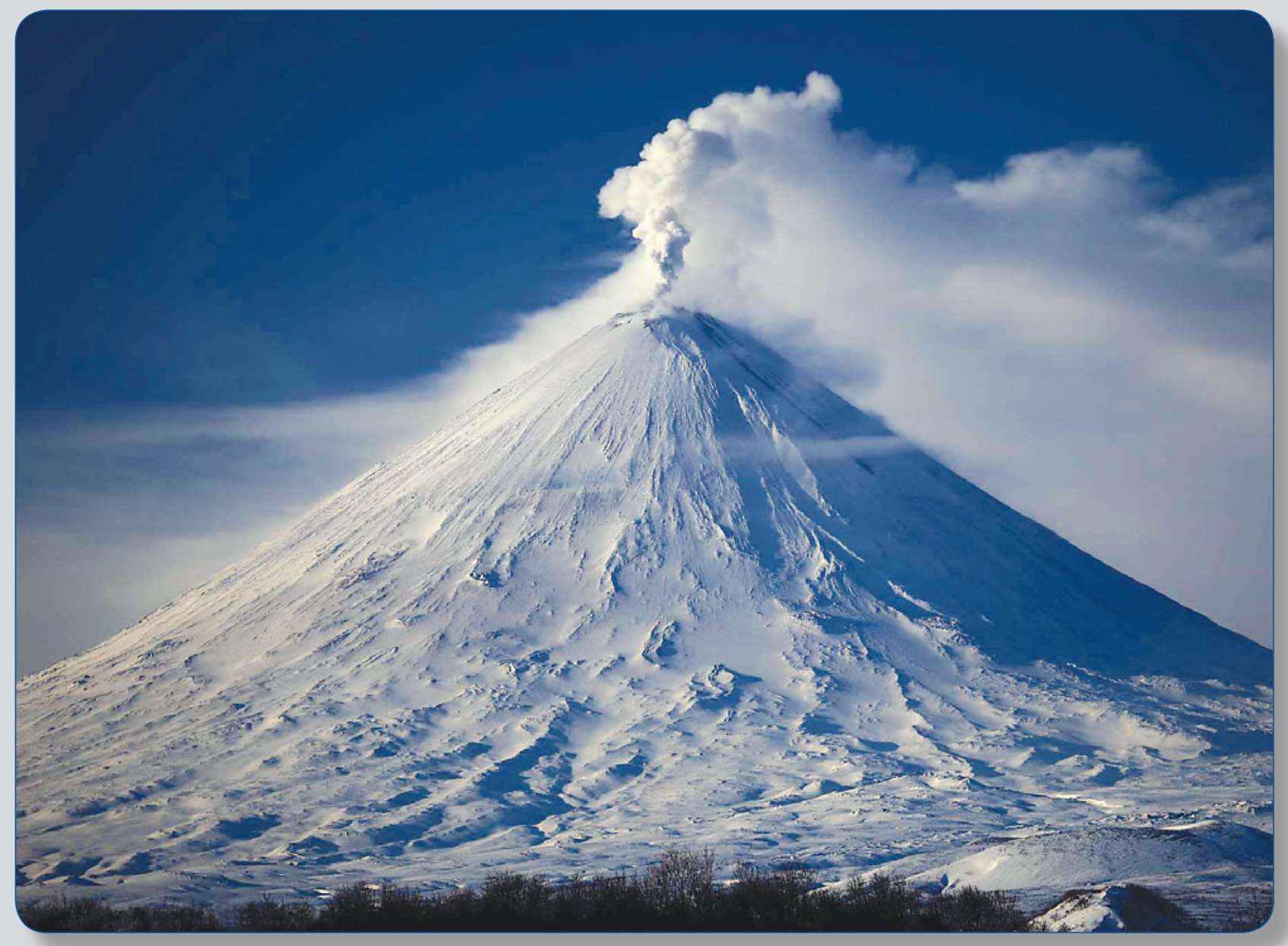

Scientific Investigations Report 2014-5034 
Cover: Klyuchevskoy Volcano in eruption, March 20, 2010. Photograph by Yury Demyanchuk, Institute of Volcanology and Seismology. Used with permission. 


\section{Volcanic Activity in Alaska, Kamchatka, and the Kurile Islands: Summary of Events and Response of the Alaska Volcano Observatory}

By Christina A. Neal, Julie Herrick, Olga A. Girina, Marina Chibisova, Alexander Rybin, Robert G. McGimsey, and Jim Dixon

The Alaska Volcano Observatory is a cooperative program of the U.S. Geological Survey, University of Alaska Fairbanks Geophysical Institute, and the Alaska Division of Geological and Geophysical Surveys. The Alaska Volcano Observatory is funded by the U.S. Geological Survey Volcano Hazards Program and the State of Alaska.

Scientific Investigations Report 2014-5034 


\title{
U.S. Department of the Interior SALLY JEWELL, Secretary
}

\section{U.S. Geological Survey Suzette M. Kimball, Acting Director}

\author{
U.S. Geological Survey, Reston, Virginia: 2014
}

For more information on the USGS - the Federal source for science about the Earth, its natural and living resources, natural hazards, and the environment, visit http://www.usgs.gov or call 1-888-ASK-USGS.

For an overview of USGS information products, including maps, imagery, and publications, visit http://www.usgs.gov/pubprod

To order this and other USGS information products, visit http://store.usgs.gov

Any use of trade, firm, or product names is for descriptive purposes only and does not imply endorsement by the U.S. Government.

Although this information product, for the most part, is in the public domain, it also may contain copyrighted materials as noted in the text. Permission to reproduce copyrighted items must be secured from the copyright owner.

Suggested citation:

Neal, C.A., Herrick, J., Girina, O.A., Chibisova, M., Rybin, A., McGimsey, R.G., and Dixon, J., 2014, 2010 Volcanic activity in Alaska, Kamchatka, and the Kurile Islands-Summary of events and response of the Alaska Volcano Observatory: U.S. Geological Survey Scientific Investigations Report 2014-5034, 76 p., http://dx.doi.org/10.3133/ sir20145034.

ISSN 2328-0328 (online) 


\section{Contents}

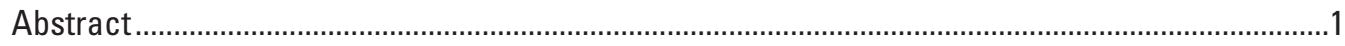

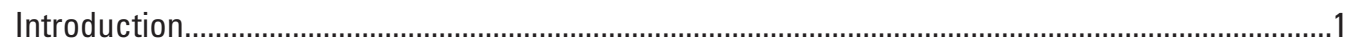

Volcanic Activity in Alaska, Northeast To Southwest Along Aleutian Arc.....................................17

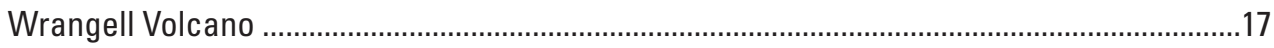

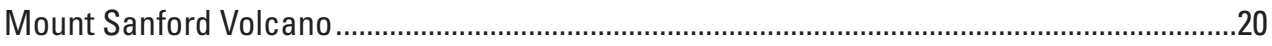

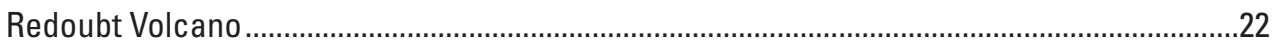

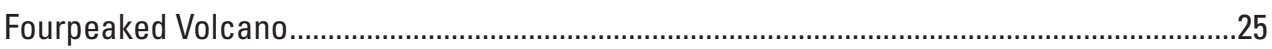

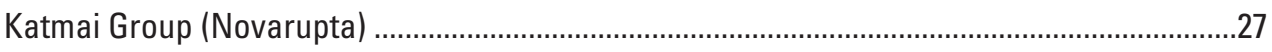

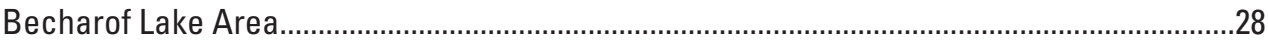

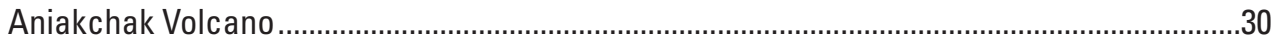

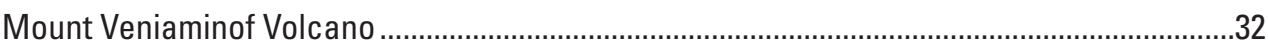

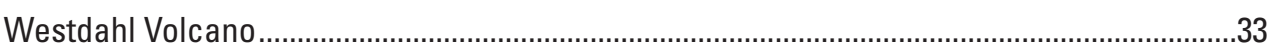

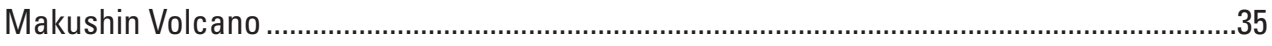

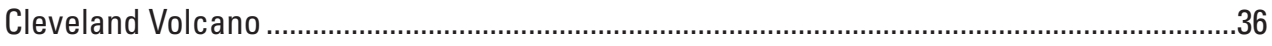

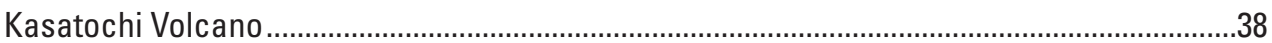

Volcanic Activity, Kamchatka Peninsula, and the Northern Kurile Islands, Russia .......................40

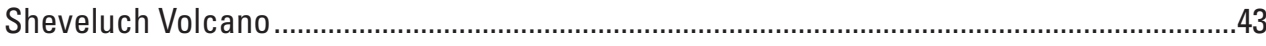

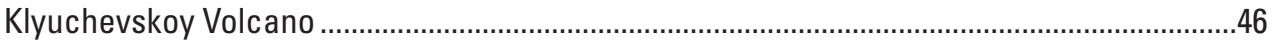

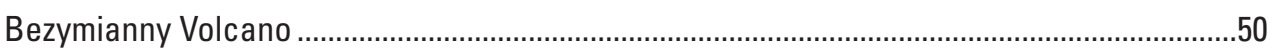

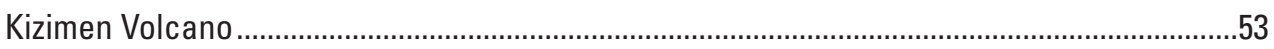

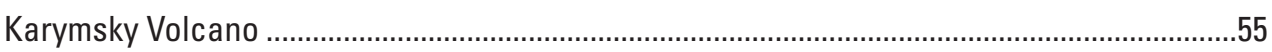

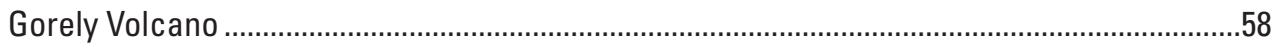

Volcanic Activity, Central and Southern Kurile Islands, Russia ......................................................61

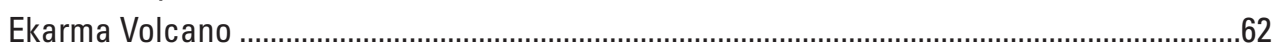

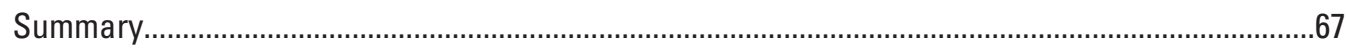

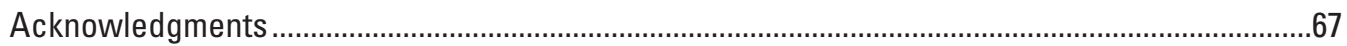

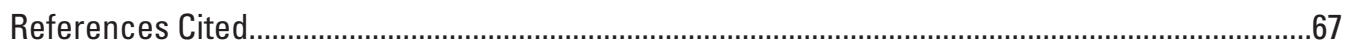

Glossary of Selected Terms and Acronyms ......................................................................................73

Appendix 1. Volcano Alert Levels and Aviation Color Codes Used by United States Volcano Observatories, KVERT, and SVERT 


\section{Figures}

1. Map showing 52 historically active volcanoes in Alaska along with place names used in this report.

2. Oblique aerial photograph of the summit of Wrangell volcano, north at the top, June 15, 1948

3. Lidar image of the summit of Wrangell volcano

4. Cross section from southeast to northwest along the center track of the lidar swath over North Crater at the summit of Wrangell volcano

5. Photograph showing suspect cloud over summit of Wrangell volcano............................19

6. Photograph showing cloud from Mount Sanford............................................................20

7. Photograph showing cloud from Mount Sanford as viewed looking north from mile 5.5 of the Old Edgerton Highway in Kenny Lake, Alaska .........................................21

8. Photograph showing aerial view of the cooling 2009 lava dome at Redoubt Volcano ...23

9. Photograph showing geologist Steve Anderson (circled) approaches the toe of the Redoubt lava dome

10. Photograph showing oblique aerial view of Redoubt Volcano ........................................24

11. Photograph showing aerial view of the northwestern flank of Fourpeaked ...................25

12. MODIS Aqua $1 \mathrm{~km}$ true color satellite image showing resuspended volcanic ash cloud (arrow) generated from high winds scouring exposed ash on the Pacific side of the Katmai volcanic range....

13. The Becharof swarm is the largest earthquake swarm since the Ugashik-Peulik seismograph network was installed in 1994 ..............................................................29

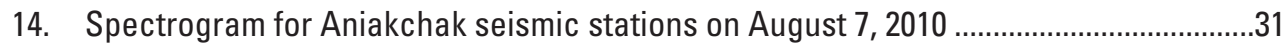

15. Plots of located events per month at Westdahl Volcano from 2002 through 2010 ...........34

16. Photograph showing oblique aerial view of the summit of Makushin Volcano...............35

17. Cropped $15-\mathrm{m}$ resolution ASTER visible/near infrared image showing recent debris flow and ash fall deposits on Cleveland Volcano.

18. Focal mechanisms for earthquakes during the July 2010 sequence in the central Aleutian Islands.

19. Photograph showing view from the crater rim of the lake surface within Kasatochi Volcano's summit crater..

20. Photograph showing coastline of Kasatochi Volcano .

21. Map showing Kamchatka Peninsula and the northern Kurile Islands of Alaid and Paramushir Volcanoes discussed in this report are in bold red type ..............................40

22. Photograph showing ash plume from Sheveluch activity

23. AVHRR satellite image showing Sheveluch ash cloud drifting downwind over the Bering Sea toward the central Aleutian Islands on October 28, 2010 ...

24. Photograph showing gas-water vapor plume containing minor amounts of ash drifting downwind from Klyuchevskoy Volcano 


\section{Figures-Continued}

25. Photograph showing phreatic activity on the southwestern flank of Klyuchevskoy

Volcano.

26. Photograph showing view of the southwestern flank of Klyuchevskoy Volcano showing the new fissure (steaming) and adjacent active lava flow filling the Kozyrevsky chute.

27. Photograph showing strombolian activity at the summit of Klyuchevskoy Volcano.......49

28. AVHRR satellite image showing tremendous downwind extent of the Klyuchevskoy ash and gas plume at 18:04 UTC on October 31, 2010

29. Photograph showing Bezymianny Volcano and the active lava dome, here producing a fumarolic plume

30. Plot of the maximum AVHRR satellite brightness temperature (pink dots; degrees

C) and the number of elevated-temperature pixels (dark diamonds), and background temperatures (blue triangles) for observed thermal anomalies over the summit area of Bezymianny Volcano (December 7, 2009 through January 11, 2011)

31. AVHRR satellite image of Kamchatka on May 31, 2010, at 21:04 UTC showing color-enhanced ash cloud from Bezymianny Volcano nearly 9 hours after the onset of explosive activity.

32. Photograph showing oblique aerial view, towards the northeast, of the early

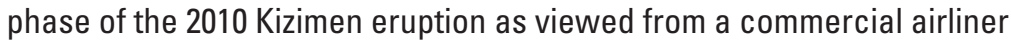

33. Photograph showing ash-covered eastern flank of Kizimen Volcano following the strong explosions of December 12, 2010.

34. Photograph showing typical Vulcanian explosion at Karymsky......................................56

35. Photograph showing typical Strombolian activity at Karymsky ......................................57

36. Plot showing amplitude of volcanic tremor in June 2010 of Gorely Volcano ...................58

37. Photograph showing incandescence visible in the 20 -m-wide $(65 \mathrm{ft})$ orifice of a newly formed fumarole inside the Gorely crater.

38. Photograph showing fumarolic plume from Gorely volcano . .59

39. Photograph showing reflection of incandescence from the hot gas plume exiting the crater of Gorely volcano .60

40. Map of Kurile Island Volcanoes from Neal and others (2008)

41. Photograph showing sailing training vessel "Nadezhda" in front of Ekarma Volcano ..62

42. Photograph showing southeastern flank of Ekarma Volcano. . .63

43. Ekarma Island as seen in an International Space Station image in September 2009.....64

44. Views of Ekarma Volcano from Skala Dolgaya Island ( $42 \mathrm{~km}$ or $26 \mathrm{mi}$ southwest of Ekarma Island) during June 2010

45. Photograph showing steam-gas emission from Ekarma Volcano...................................65

46. Photographs showing impacts of the June 2010 eruption of Ekarma . .66 


\section{Tables}

1. History of seismic monitoring of Alaskan volcanoes from August 1971 through December 2010

2. Summary of $\mathbf{2 0 1 0}$ volcanic activity in Alaska, including actual eruptions, possible eruptions, unusual increases in seismicity or fumarolic activity .6

3. Alaskan volcanoes with Aviation Color Code and Alert Level changes in 2010 .6

4a. Compilation by year of volcanoes included in an Alaska Volcano Observatory Annual Summary, 1992-2010.

4b. Compilation by volcano for particular years included in an Alaska Volcano Observatory Annual Summary, 1992-2010.

4c. Citations for Alaska Volcano Observatory Annual Summary reports, 1992-2010.............15

5. Seismically monitored volcanoes of Kamchatka as of December 2010 .........................41

6. Summary of volcanic activity on Kamchatka Peninsula and in the Kurile Islands, Russia, 2010

7. Aviation Color Code changes for Kamchatkan volcanoes in 2010 


\title{
Conversion Factors and Datum
}

\author{
Conversion Factors
}

Inch-Pound to SI

\begin{tabular}{lcl}
\hline \multicolumn{1}{c}{ Multiply } & By & \multicolumn{1}{c}{ To obtain } \\
\hline acre & 4,047 & square meter $\left(\mathrm{m}^{2}\right)$ \\
cubic mile $\left(\mathrm{mi}^{3}\right)$ & 4.168 & cubic kilometer $\left(\mathrm{km}^{3}\right)$ \\
foot (ft) & 0.000305 & kilometer $(\mathrm{km})$ \\
foot (ft) & 0.3048 & meter $(\mathrm{m})$ \\
inch (in) & 2.54 & centimeter $(\mathrm{cm})$ \\
inch (in) & 25.4 & millimeter (mm) \\
mile (mi) & 1.609 & kilometer $(\mathrm{km})$ \\
ton per day (ton/d) & 0.9072 & metric ton per day \\
\hline
\end{tabular}

Temperature in degrees Fahrenheit $\left({ }^{\circ} \mathrm{F}\right)$ may be converted to degrees Celsius $\left({ }^{\circ} \mathrm{C}\right)$ as follows:

$$
{ }^{\circ} \mathrm{C}=\left({ }^{\circ} \mathrm{F}-32\right) / 1.8
$$

SI to Inch-Pound

\begin{tabular}{lcl}
\hline \multicolumn{1}{c}{ Multiply } & \multicolumn{1}{c}{ By } & \multicolumn{1}{c}{ To obtain } \\
\hline cubic kilometer $\left(\mathrm{km}^{3}\right)$ & 0.2399 & cubic mile $\left(\mathrm{mi}^{3}\right)$ \\
kilometer $(\mathrm{km})$ & 0.6214 & mile (mi) \\
kilometer $(\mathrm{km})$ & 3,281 & foot (ft) \\
meter $(\mathrm{m})$ & 3.281 & foot $(\mathrm{ft})$ \\
centimeter $(\mathrm{cm})$ & 0.3937 & inches (in) \\
metric ton per day & 1.1022 & ton per day (ton/d) \\
millimeter $(\mathrm{mm})$ & 0.03937 & inch (in) \\
square meter $\left(\mathrm{m}^{2}\right)$ & 0.0002471 & acre \\
\hline
\end{tabular}

Temperature in degrees Celsius $\left({ }^{\circ} \mathrm{C}\right)$ may be converted to degrees Fahrenheit $\left({ }^{\circ} \mathrm{F}\right)$ as follows:

$$
{ }^{\circ} \mathrm{F}=\left(1.8 \times{ }^{\circ} \mathrm{C}\right)+32 \text {. }
$$

Datum

Altitude and elevation, as used in this report, refers to distance above sea level, unless otherwise noted. 



\title{
2010 Volcanic Activity in Alaska, Kamchatka, and the Kurile Islands-Summary of Events and Response of the Alaska Volcano Observatory
}

\author{
By Christina A. Neal1, Julie Herrick², Olga A. Girina3, Marina Chibisova4, Alexander Rybin', Robert \\ McGimsey ${ }^{1}$, and Jim Dixon ${ }^{1}$
}

\begin{abstract}
The Alaska Volcano Observatory (AVO) responded to eruptions, possible eruptions, volcanic unrest or suspected unrest at 12 volcanic centers in Alaska during 2010. The most notable volcanic activity consisted of intermittent ash emissions from long-active Cleveland volcano in the Aleutian Islands. AVO staff also participated in hazard communication regarding eruptions or unrest at seven volcanoes in Russia as part of an ongoing collaborative role in the Kamchatka and Sakhalin Volcanic Eruption Response Teams.
\end{abstract}

\section{Introduction}

The Alaska Volcano Observatory (AVO) monitors, studies, and warns of volcanic unrest at Alaskan volcanoes. In addition, AVO collaborates with Russian volcanologists and meteorologists from the U.S. National Weather Service and their counterparts in Russia and Japan to examine satellite data for Russian volcanoes and disseminate information regarding dangerous ash eruptions in the Russian Far East. Primary responsibility for tracking and reporting on volcanic eruptions in Russia lies with two organizations: the Kamchatka Volcanic Eruption Response Team (KVERT) and the Sakhalin Volcanic Eruption Response Team (SVERT; Neal and others, 2009a).

As of December 31, 2010, 30 of the 52 historically active volcanoes in Alaska are instrumented with a network of seismometers sufficiently reliable in their operation to detect and track earthquake activity (fig. 1; table 1). Seismic stations were installed at two additional volcanoes in 2005 (Little Sitkin and Semisopochnoi; fig. 1); however, telemetry links have remained intermittently operational and AVO does not consider these volcanoes to be seismically monitored. Four volcanoes whose monitoring networks had suffered outages of sufficient length to delist them as monitored in 2009 (Fourpeaked, Aniakchak, Korovin, and Veniaminof; Dixon and others, 2011) were returned to monitored status by the end of 2010.

AVO's volcano monitoring program also includes twice-daily analysis of satellite imagery and web cameras, occasional overflights, airborne-gas measurements, compilation of pilot reports (PIREPS), and observations of local residents and mariners. AVO also receives realtime deformation data from permanent Global Positioning System (GPS) stations at four Alaskan volcanoes (Okmok, Augustine, Akutan, and Mount Spurr). Periodic analysis of Interferometric Synthetic Aperture Radar (InSAR) imagery also is used to detect deformation at volcanoes in Alaska (for example, $\mathrm{Lu}, 2007$ ).

As part of its cooperative monitoring and response activities for the Russian Far East volcanoes, in 2010, AVO assisted in broadcasting alerts about eruptive activity at six volcanoes in Kamchatka (Sheveluch, Klyuchevskoy, Bezymianny, Kizimen, Karymsky, Gorely) and one in the Kurile Islands (Ekarma). This will be the final year of combined Alaska and Russia reporting in this annual activity series.

\footnotetext{
${ }^{1}$ U.S. Geological Survey, Alaska Volcano Observatory, 4230 University Dr., Anchorage, Alaska 99508-4664.

${ }^{2}$ Global Volcanism Program, National Museum of Natural History, Smithsonian Institution, MRC 119, PO Box 37012, Washington, DC

${ }^{3}$ Kamchatka Volcanic Eruptions Response Team, Institute of Volcanology and Seismology, Piip Blvd., 9 Petropavlovsk-Kamchatsky, Russia 683006.

${ }^{4}$ Sakhalin Volcanic Eruptions Response Team, Institute of Marine Geology and Geophysics, Nauki Street, Yuzhno-Sakhalinsk, Russia 693022.
} 


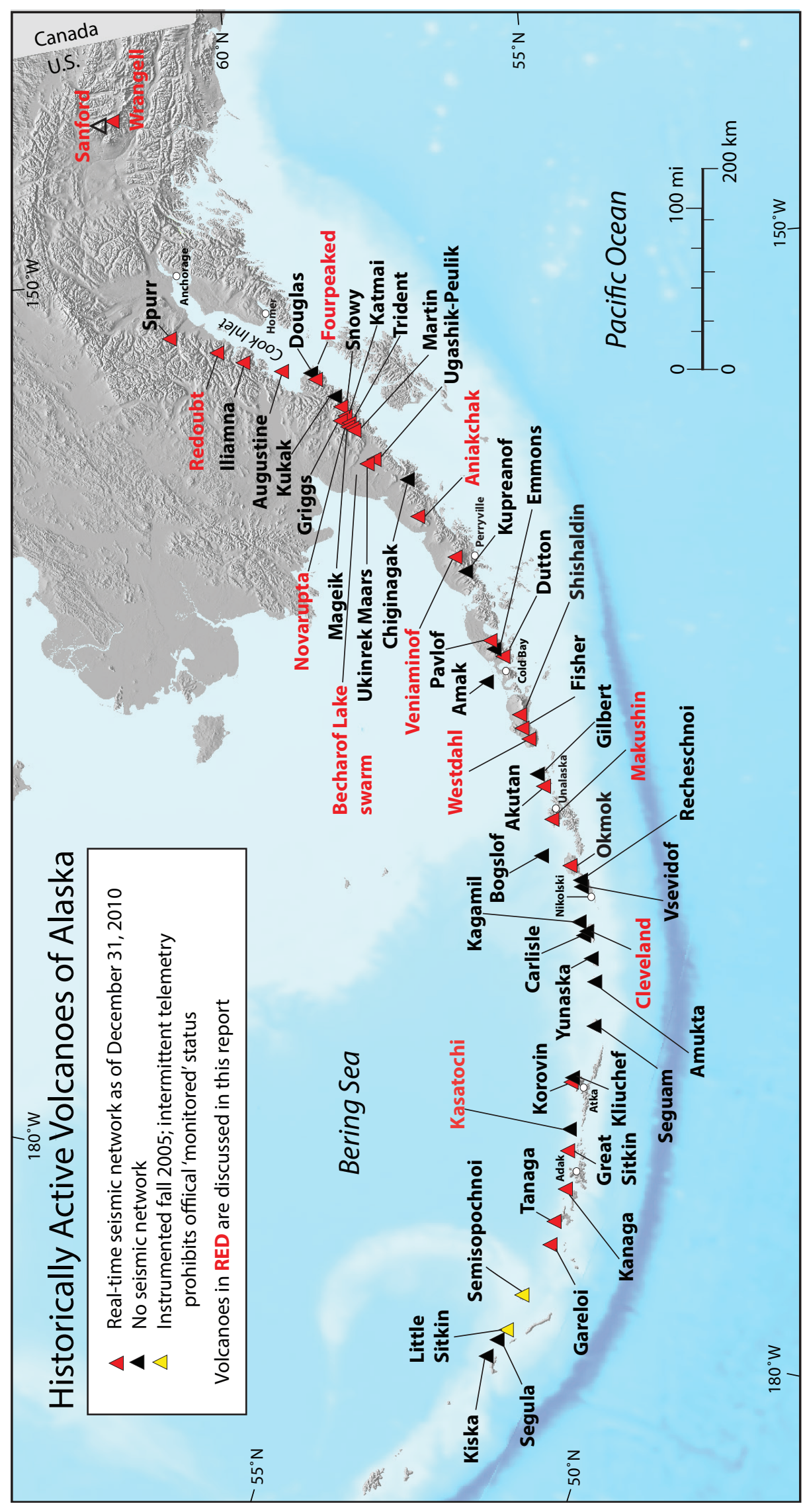

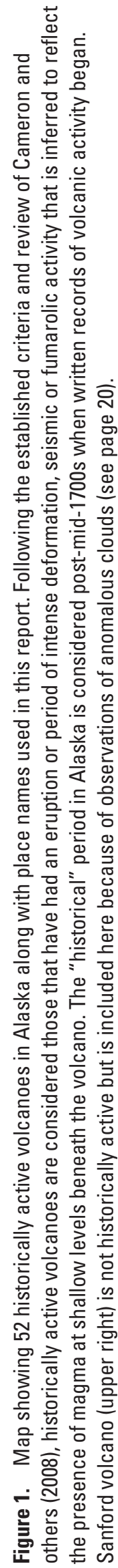


Table 1. History of seismic monitoring of Alaskan volcanoes from August 1971 through December 2010.

[History of seismic monitoring compiled by J. Dixon. "First station installed" refers to the date when the Alaska Volcano Observatory (AVO) first received real-time data from the station. This date can be many months following initial fieldwork at the volcano. AVO considers the seismic network "complete" following installation and data transmission from a minimum of four seismic stations. Typically, AVO seismologists wait about six months or more to understand background rates of seismicity before formally declaring a volcano seismically monitored and adding it to the monitored list. We note here the first mention of the seismic status of each monitored volcano in the AVO weekly update. Regularly issued written information statements began during the Redoubt eruption in 1989-90 and were expanded to include all Cook Inlet volcanoes in April 1991. The Magnitude of Completeness is the lowest magnitude that can confidently be located for activity detected in 2010. For more information on specific seismic network histories, readers are referred to the series of annual seismic summaries prepared by AVO (for example, Dixon and others, 2011)]

\begin{tabular}{l} 
Volcano \\
\hline Wrangell \\
Spurr \\
Redoubt \\
Iliamna \\
Augustine \\
Fourpeaked \\
Krident)
\end{tabular}

Katmai-South (Martin, Mageik)

First station installed - July 2000

Network complete - August 2001

Magnitude of completeness

Added to monitored list in weekly update - November 2001

First station installed - August 1971

0.9

Network complete - August 1989

Added to monitored list in weekly update - April 1991

First station installed - August 1971

Network complete - August 1988

Added to monitored list in weekly update - April 1991

First station installed - September 1987

Network complete (Min 4 stations) - September 1994

Added to monitored list in weekly update - April 1991

First station installed - October 1976

Network complete - August 1978

Added to monitored list in weekly update - April 1991

First station installed - September 2006

Network complete (Min 4 stations) - October 2006

Added to monitored list in weekly update - October 2006

First station installed - August 1988

Network complete - October 1998

Added to monitored list in weekly update - December 1998

First station installed - August 1988

Network complete (Min 4 stations) - July 1991

Added to monitored list in weekly update - November 1996

First station installed - August 1988

Network complete - July 1996

Added to monitored list in weekly update - November 1996

Ukinrek Maars/ Peulik

First station installed - March 2005

Network complete (Min 4 stations) - March 2005

Added to monitored list in weekly update - April 2005

Aniakchak

First station installed - July 1997

Network complete - July 1997

Added to monitored list in weekly update - November 1997

Veniaminof

First station installed - February 2002

Network complete - February 2002

Added to monitored list in weekly update - September 2002

Pavlof

First station installed - July 1996

Network complete - July 1996

Added to monitored list in weekly update - November 1996

Dutton

First station installed - July 1988

Network complete - July 1996

Added to monitored list in weekly update - November 1996 
Table 1. History of seismic monitoring of Alaskan volcanoes from August 1971 through December 2010.-Continued

[History of seismic monitoring compiled by J. Dixon. "First station installed" refers to the date when AVO first received real-time data from the station. This date can be many months following initial fieldwork at the volcano. Alaska Volcano Observatory (AVO) considers the seismic network "complete" following installation and data transmission from a minimum of four seismic stations. Typically, AVO seismologists wait about six months or more to understand background rates of seismicity before formally declaring a volcano seismically monitored and adding it to the monitored list. We note here the first mention of the seismic status of each monitored volcano in the AVO weekly update. Regularly issued written information statements began during the Redoubt eruption in 1989-90 and were expanded to include all Cook Inlet volcanoes in April 1991. The Magnitude of Completeness is the lowest magnitude that can confidently be located for activity detected in 2010. For more information on specific seismic network histories, readers are referred to the series of annual seismic summaries prepared by AVO (for example, Dixon and others, 2011]

\begin{tabular}{|c|c|c|}
\hline Volcano & Approximate start date of seismic monitoring & $\begin{array}{l}\text { Magnitude of } \\
\text { completeness }\end{array}$ \\
\hline Shishaldin (and Isantoski) & $\begin{array}{l}\text { First station installed - July } 1997 \\
\text { Network complete - July } \mathbf{1 9 9 7} \\
\text { Shishaldin added to list in weekly update - November } 1997 \\
\text { Isantoski added to list in weekly update - December } 1998\end{array}$ & 0.5 \\
\hline Westdahl (and Fisher) & $\begin{array}{l}\text { First station installed - August } 1998 \\
\text { Network complete - October } 1998 \\
\text { Added to monitored list in weekly update - December } 1998\end{array}$ & 1.1 \\
\hline Akutan & $\begin{array}{l}\text { First station installed - March } 1996 \\
\text { Network complete - July } 1996 \\
\text { Added to monitored list in weekly update - November } 1996\end{array}$ & 1.5 \\
\hline Makushin & $\begin{array}{l}\text { First station installed - July } 1996 \\
\text { Network complete - July } 1996 \\
\text { Added to monitored list in weekly update - November } 1996\end{array}$ & 0.7 \\
\hline Korovin & $\begin{array}{l}\text { First station installed - July } 2004 \\
\text { Network complete - July } \mathbf{2 0 0 4} \\
\text { Added to monitored list in weekly update - December } 2005\end{array}$ & 0.9 \\
\hline Great Sitkin & $\begin{array}{l}\text { First station installed - September } 1999 \\
\text { Network complete - September } 1999 \\
\text { Added to monitored list in weekly update - December } 1999\end{array}$ & 1.2 \\
\hline Kanaga & $\begin{array}{l}\text { First station installed - September } 1999 \\
\text { Network complete - September } 1999 \\
\text { Added to monitored list in weekly update - December } 2000\end{array}$ & 1.7 \\
\hline Semisopochnoi (Cerberus) & $\begin{array}{l}\text { First station installed - September } 2005 \\
\text { Network complete - September } 2005 \\
\text { Added to monitored list in weekly update - not yet added }\end{array}$ & 0.6 \\
\hline Little Sitkin & $\begin{array}{l}\text { First station installed - September } 2005 \\
\text { Network complete - September } 2005 \\
\text { Added to monitored list in weekly update - not yet added }\end{array}$ & 1.1 \\
\hline
\end{tabular}


This report summarizes volcanic activity in Alaska, Kamchatka, and the Kuriles in 2010 and briefly describes AVO's operational response. We include information on all volcanoes at elevated alert status and those that prompted significantly increased attention by AVO staff, even if no formal public notification ensued. We also include observations, images, and data that would be difficult to publish elsewhere. This summary complements the focused annual seismic catalog publications of AVO that detail earthquake monitoring results for all Alaskan volcanoes on an annual basis (see Dixon and others, 2011, for an example).

Descriptions are presented in geographic order from northeast to southwest along the Aleutian Arc, and north to south in the Russian Far East. For each entry, a title block containing the volcanoes unique identifier (CAVW\#) from the Catalog of Active Volcanoes of the World (Siebert and others, 2010) is followed by the volcano's latitude and longitude, summit elevation, and region of occurrence. Each event summary ends with a paragraph of background comments about the volcano in question. Information is derived from published material as well as AVO daily status reports, weekly updates and special information releases, AVO email and online electronic logs, and the Smithsonian Institution Global Volcanism Network Bulletins that are available at URL: http:// www.volcano.si.edu/. Note that spelling of Russian volcano names may vary slightly from source to source; we use here spellings that have been in use since the early 1990s by AVO, KVERT, and SVERT.

Table 1 is a history of seismic monitoring of Alaskan volcanoes from August 1971 through December 2010. Table 2 summarizes 2010 volcanic activity in Alaska. Table 3 lists changes in Aviation Color Codes in 2010 for Alaskan volcanoes. Descriptions of Aviation Color Codes and Volcano Alert Levels used in Alaska and Russia are presented in $\underline{\text { appendix } 1 .}$. Tables 4a, $\underline{4 b}$, and $\underline{4 c}$ present cross-referenced lists of volcanic activity by year and by volcano for this and all previous AVO annual activity reports. Citations for all AVO Annual Summary reports (covering the years 1992 to 2010) also are available at this URL: http://www.avo.alaska.edu/ downloads/classresults.php?pregen=annsum.

\section{What is an "eruption"?}

The specific use of the term "eruption" varies from scientist to scientist and there is no universally agreed-upon definition. Here, we adopt the usage of the Smithsonian Institution's Global Volcanism Program, which defines eruptions as "...events that involve the explosive ejection of fragmental material, the effusion of liquid lava, or both. Other definitions restrict eruptions to magmatic events, but the fragmental material ejected may be old as well as new. The explosive interaction of volcanically generated heat and near-surface water can cause dramatic eruptions without any fresh volcanic material reaching the surface and from a volcanic hazards perspective can be as important to document as magmatic events.." (http://www.volcano.si.edu/faq.cfm\#q2). The elements of this definition that we wish to emphasize are the verbs "eject" and "effuse," which refer to dynamic surface processes that pose some level of hazard. The presence or absence of often ambiguous 'juvenile material' or fresh magma is not relevant to this use of the term eruption, particularly when communicating a potential hazard. This definition would not, however, include passive volcanic degassing or hydrothermalfluid discharge.

\section{What is an "historically active volcano"?}

AVO defines an "active" volcano as a volcanic center that has had a recent eruption (see above) or period of intense deformation, seismic or fumarolic activity that is inferred to reflect the presence of magma at shallow levels within the volcano. The "historic" period in Alaska is now considered to be post mid-1700s when written records of volcanic activity began. Based on a rigorous re-analysis of all accounts of volcanic activity in Alaska from many sources, Cameron and others (2008) conclude that 52 Alaskan volcanoes fit these criteria. This is a change from the oft-cited 41 of Miller and others (1998), and from previously published map compilations. As geologic understanding of Alaska's volcanoes improves through additional fieldwork and modern radiometric-dating techniques, our list of "active" volcanoes will continue to evolve. A case in point from 2006: Fourpeaked Mountain, thought not to have erupted in the Holocene, produced a phreatic eruption in the fall of 2006. It now ranks as an historically active volcano, despite not appearing on the list prior to 2006. The AVO annual summary often contains information about reports of unusual activity-non-volcanic in nature, but mistaken by local observers to be volcanic activity-at volcanoes that are not considered "historically active"; they are included because AVO staff spent significant time responding to the reports/observations. 
Table 2. Summary of 2010 volcanic activity in Alaska, including actual eruptions, possible eruptions, unusual increases in seismicity or fumarolic activity.

[Location of volcanoes shown in figure 1]

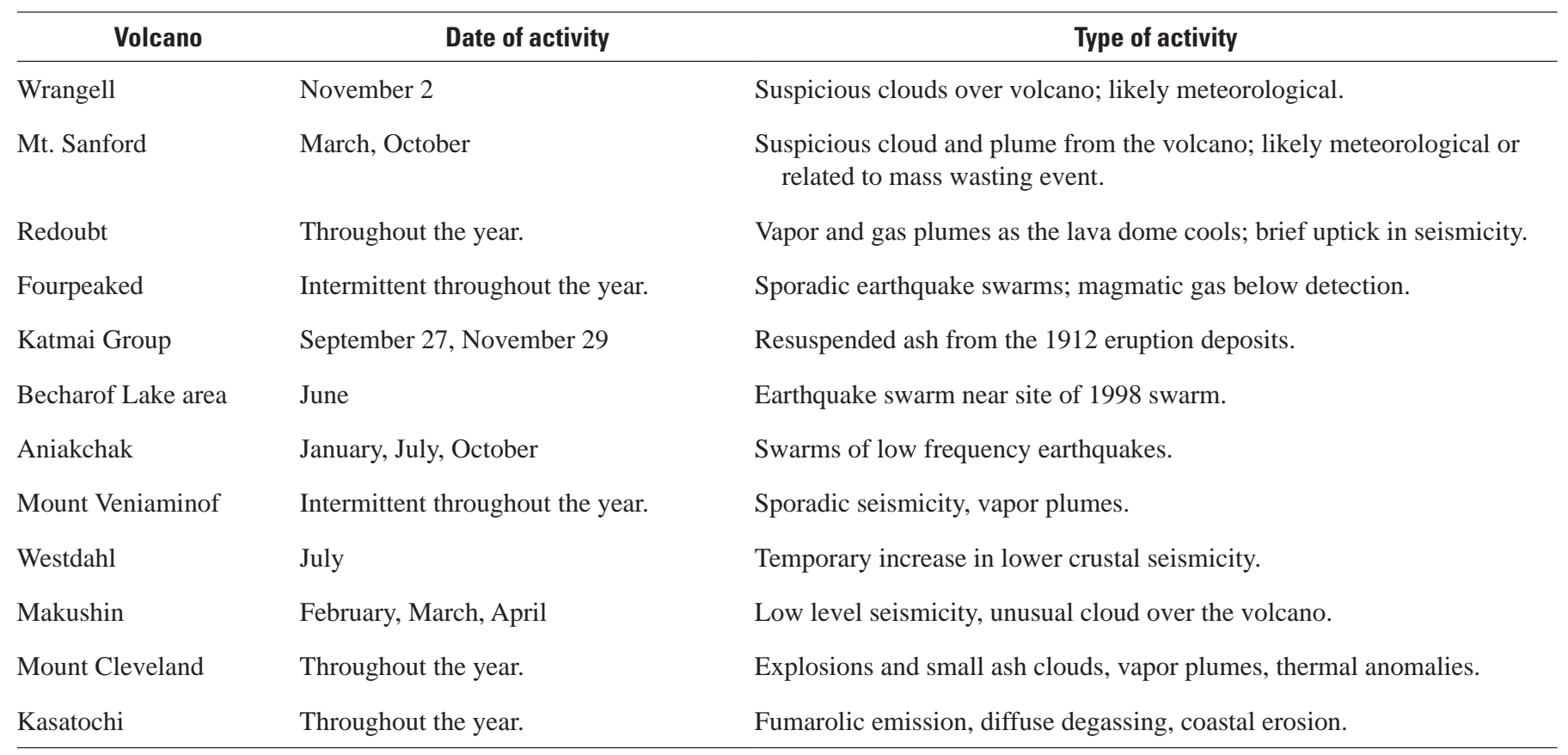

Table 3. Alaskan volcanoes with Aviation Color Code and Alert Level changes in 2010.

[Description of Aviation Color Codes is shown in appendix 1. Local times are only shown where color code changes were short-lived during rapidly evolving events. Volcanoes that do not have a real-time seismic network are not assigned a color code GREEN because without seismic data, Alaska Volcano Observatory has no definitive information that the level of activity at the volcano is at background. For these volcanoes, AVO uses the designation UNASSIGNED]

\begin{tabular}{|l|l|}
\hline \multicolumn{2}{|c|}{ Color Code } \\
\hline \multicolumn{2}{|c|}{ REDOUBT } \\
\hline YELLOW/ADVISORY & January 1-January 5 \\
\hline GREEN/NORMAL & January 5-April 5 \\
\hline YELLOW/ADVISORY & April 5-April 12 \\
\hline GREEN/NORMAL & April 12-December 31 \\
\hline \multicolumn{2}{|c|}{ CLEVELAND } \\
\hline UNASSIGNED & January 1-May 25 \\
\hline YELLOW/ADVISORY & May 25-June 11 \\
\hline UNASSIGNED & June 11-August 26 \\
\hline YELLOW/ADVISORY & August 26-September 10 \\
\hline UNASSIGNED & September 10-September 12 \\
\hline YELLOW & September 12-December 31 \\
\hline
\end{tabular}

Altitudes and elevations reported are in feet or meters above sea level (ASL) unless noted otherwise. Time is reported as Alaska Standard Time (AKST), Alaska Daylight Time (AKDT), Kamchatkan Standard Time (KST), or Kamchatkan Daylight Time (KDT) as needed. For most satellite or geophysical instrumentation references, times are given in Coordinated Universal Time (UTC). We preserve English or Inch-Pound units of measurement especially where they reflect the primary observations of distance or altitude such as those commonly received via pilot reports and aviation authorities in the United States. Elsewhere, measurements are presented in International System of Units (SI) with approximate conversions to Inch-Pound Units in parentheses for convenience. Volcano locations in latitude and longitude (presented in degrees and minutes rounded to the nearest minute) and summit elevations are taken from the Alaska Volcano Observatory database (WGS 1984 datum) and may differ slightly from previously published compilations. For Russian volcanoes, we adopt the location and elevation information of KVERT and SVERT. These, too, may differ slightly from previous compilations and from the Smithsonian Global Volcanism database. 
Table 4a. Compilation by year of volcanoes included in an Alaska Volcano Observatory Annual Summary, 1992-2010.

[Volcanoes are presented in geographical order from northeast to southwest along the Wrangell-Aleutian volcanic arc and north to south along Kamchatka and the Kurile Islands. Prior to 1995, Alaska Volcano Observatory did not report on Russian volcanoes]

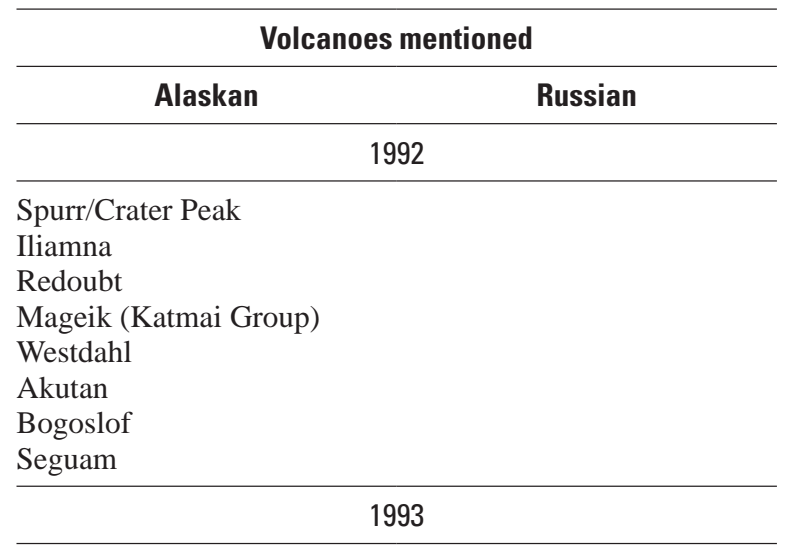

\section{Churchill}

Sanford

Spurr/Crater Peak

Veniaminof

Shishaldin

Makushin

Seguam

Kliuchef (Atka)

Kanaga

1994

\section{Sanford}

Iliamna

Katmai Group (Martin, Mageik, Trident)

Veniaminof

Kupreanof

Shishaldin

Makushin

Cleveland

Kanaga

1995

\begin{tabular}{ll}
\hline & 1995 \\
\hline $\begin{array}{l}\text { Katmai Group (Martin) } \\
\text { Veniaminof }\end{array}$ & Bezymianny \\
Shishaldin & Karymsky \\
Makushin & \\
Kliuchef (Atka) & \\
Kanaga & \\
\hline & 1996 \\
\hline Wrangell & Klyuchevskoy \\
Iliamna & Bezymianny \\
Katmai Group (Martin, & Karymsky \\
$\quad$ Mageik, Trident, Mount & \\
$\quad$ Katmai) & \\
Pavlof & Avachinsky \\
Shishaldin & Mutnovsky \\
Westdahl & Alaid (Kurile Islands) \\
Akutan & \\
Amukta & \\
Korovin (Atka) & \\
Kanaga &
\end{tabular}

\begin{tabular}{|c|c|}
\hline \multicolumn{2}{|c|}{ Volcanoes mentioned } \\
\hline Alaskan & Russian \\
\hline \multicolumn{2}{|c|}{1997} \\
\hline $\begin{array}{l}\text { Wrangell } \\
\text { Sanford } \\
\text { Shrub Mud } \\
\text { Iliamna } \\
\text { Katmai Group (Martin, } \\
\quad \text { Mageik, Snowy, Kukak) } \\
\text { Chiginagak } \\
\text { Pavlof } \\
\text { Shishaldin } \\
\text { Okmok } \\
\text { Cleveland } \\
\text { Amukta }\end{array}$ & $\begin{array}{l}\text { Sheveluch } \\
\text { Klyuchevskoy } \\
\text { Bezymianny } \\
\text { Karymsky } \\
\text { Alaid (Kurile Islands) }\end{array}$ \\
\hline \multicolumn{2}{|c|}{1998} \\
\hline $\begin{array}{l}\text { Shrub Mud } \\
\text { Augustine } \\
\text { Becharof Lake } \\
\text { Chiginagak } \\
\text { Shishaldin } \\
\text { Akutan } \\
\text { Korovin (Atka) }\end{array}$ & $\begin{array}{l}\text { Sheveluch } \\
\text { Klyuchevskoy } \\
\text { Bezymianny } \\
\text { Karymsky }\end{array}$ \\
\hline & \\
\hline
\end{tabular}

\begin{tabular}{ll}
\hline Wrangell & Sheveluch \\
Shrub Mud & Klyuchevskoy \\
Iliamna & Bezymianny \\
Veniaminof & Karymsky \\
Pavlof & \\
Shishaldin & \\
Vsevidof & \\
\hline
\end{tabular}

\begin{tabular}{ll}
\hline Wrangell & Sheveluch \\
Katmai Group (Snowy) & Klyuchevskoy \\
Chiginagak & Bezymianny \\
Shishaldin & Karymsky \\
& Mutnovsky \\
\hline & 2001 \\
\hline
\end{tabular}

\begin{tabular}{ll}
\hline $\begin{array}{l}\text { Katmai Group } \\
\text { (Snowy/Kukak) }\end{array}$ & Sheveluch \\
Pavlof & Klyuchevskoy \\
Frosty & Bezymianny \\
Shishaldin & Karymsky \\
Makushin & Avachinsky
\end{tabular}

Okmok

Cleveland

Great Sitkin 
Table 4a. Compilation by year of volcanoes included in an Alaska Volcano Observatory Annual Summary, 1992-2010.—Continued

[Volcanoes are presented in geographical order from northeast to southwest along the Wrangell-Aleutian volcanic arc and north to south along Kamchatka and the Kurile Islands. Prior to 1995, Alaska Volcano Observatory did not report on Russian volcanoes]

\begin{tabular}{|c|c|}
\hline \multicolumn{2}{|c|}{ Volcanoes mentioned } \\
\hline Alaskan & Russian \\
\hline \multicolumn{2}{|c|}{2002} \\
\hline Wrangell & Sheveluch \\
\hline $\begin{array}{l}\text { Katmai Group (Martin, } \\
\text { Mageik) }\end{array}$ & Klyuchevskoy \\
\hline Veniaminof & Bezymianny \\
\hline $\begin{array}{l}\text { Mt. Hague (Emmons } \\
\text { Lake Caldera) }\end{array}$ & Karymsky \\
\hline Shishaldin & \\
\hline Great Sitkin & \\
\hline \multicolumn{2}{|c|}{2003} \\
\hline Wrangell & Sheveluch \\
\hline Redoubt & Klyuchevskoy \\
\hline Iliamna & Bezymianny \\
\hline Augustine & Karymsky \\
\hline Katmai Group (Mageik) & Alaid \\
\hline Veniaminof & Chikurachki \\
\hline Pavlof & \\
\hline Mt. Hague (Emmons & \\
\hline Lake Caldera) & \\
\hline Shishaldin & \\
\hline Akutan & \\
\hline \multicolumn{2}{|c|}{2004} \\
\hline
\end{tabular}

\begin{tabular}{ll}
\hline $\begin{array}{l}\text { Mt. Crillon (non-volcanic } \\
\text { peak) } \\
\text { Mount Spurr }\end{array}$ & Sheveluch \\
$\begin{array}{l}\text { Katmai Group (Martin) } \\
\text { Veniaminof } \\
\text { Shishaldin } \\
\text { Westdahl }\end{array}$ & $\begin{array}{l}\text { Klyuchevskoy } \\
\text { Bezymianny } \\
\text { Karymsky } \\
\text { Chirinkotan (Kuriles) }\end{array}$ \\
\hline & \\
\hline $\begin{array}{l}\text { Mount Spurr } \\
\text { Iliamna }\end{array}$ & 2005 \\
$\begin{array}{l}\text { Augustine } \\
\text { Katmai Group (Martin, } \\
\text { Mageik, Trident) }\end{array}$ & Sheveluch \\
Chiginagak & Klyuchevskoy \\
Aniakchak & Karymsky \\
Veniaminof & Avachinsky \\
Pavlof/Mt. Hague & Mutnovsky \\
Shishaldin & Ebeko \\
Cleveland & Chikurachki \\
Korovin & \\
Kasatochi & \\
Tanaga &
\end{tabular}

\begin{tabular}{|c|c|}
\hline \multicolumn{2}{|c|}{ Volcanoes mentioned } \\
\hline Alaskan & Russian \\
\hline \multicolumn{2}{|c|}{2006} \\
\hline Klawasi & Sheveluch \\
\hline Mount Spurr & Klyuchevskoy \\
\hline Augustine & Bezymianny \\
\hline Fourpeaked & Karymsky \\
\hline $\begin{array}{l}\text { Katmai Group (Martin, } \\
\text { Mageik, Trident) }\end{array}$ & Ebeko \\
\hline Veniaminof & Severgin \\
\hline Cleveland & Berga \\
\hline Korovin & \\
\hline Kasatochi & \\
\hline \multicolumn{2}{|c|}{2007} \\
\hline Redoubt & Sheveluch \\
\hline Augustine & Klyuchevskoy \\
\hline Fourpeaked & Bezymianny \\
\hline Veniaminof & Karymsky \\
\hline Pavlof & Gorely and Mutnovsky \\
\hline Akutan & Chikurachki \\
\hline Cleveland & Berga \\
\hline Korovin & \\
\hline \multicolumn{2}{|c|}{2008} \\
\hline Redoubt & Sheveluch \\
\hline Aniakchak & Klyuchevskoy \\
\hline Veniaminof & Bezymianny \\
\hline Shishaldin & Karymsky \\
\hline Okmok & Koryaksky \\
\hline Cleveland & Gorely and Mutnovsky \\
\hline Kasatochi & Chikurachki \\
\hline & Tyatya \\
\hline \multicolumn{2}{|c|}{2009} \\
\hline Sanford & Sheveluch \\
\hline Redoubt & Klyuchevskoy \\
\hline Fourpeaked & Bezymianny \\
\hline Aniakchak & Kizimen \\
\hline Veniaminof & Karymsky \\
\hline Shishaldin & Koryaksky \\
\hline Okmok & Gorely \\
\hline \multirow{3}{*}{ Cleveland } & Ebeko \\
\hline & Sarychev \\
\hline & Raikoke \\
\hline
\end{tabular}


Table 4a. Compilation by year of volcanoes included in an Alaska Volcano Observatory Annual Summary, 1992-2010.-Continued

[Volcanoes are presented in geographical order from northeast to southwest along the Wrangell-Aleutian volcanic arc and north to south along Kamchatka and the Kurile Islands. Prior to 1995, Alaska Volcano Observatory did not report on Russian volcanoes]

\begin{tabular}{lc}
\hline \multicolumn{1}{c}{ Alaskan } & \multicolumn{1}{c}{ Russian } \\
\hline & 2010 \\
\hline Wrangell & Sheveluch \\
Sanford & Klyuchevskoy \\
Redoubt & Bezymianny \\
Fourpeaked & Kizimen \\
Katmai Group & Karymsky \\
Becharof Lake & Gorely \\
Aniakchak & Ekarma \\
Veniaminof & \\
Westdahl & \\
Makushin & \\
Cleveland & \\
Kasatochi & \\
\hline
\end{tabular}

Table 4b. Compilation by volcano for particular years included in an Alaska Volcano Observatory Annual Summary, 1992-2010.

[Suspect Volcanic Activity (SVA) is defined as a report of eruption or possible eruption that is normal fumarolic activity or non-volcanic phenomena, such as weather related. Use of this term was suspended in 2006. PIREP, pilot weather report]

\begin{tabular}{|c|c|c|}
\hline Volcano & Year mentioned & Type of activity \\
\hline \multicolumn{3}{|r|}{ Alaska (east to west) } \\
\hline Churchill & 1993 & SVA, anomalous seismicity \\
\hline Wrangell & $\begin{array}{l}1996 \\
1997 \\
1999 \\
2000 \\
2002 \\
2003 \\
2007 \\
2010\end{array}$ & $\begin{array}{l}\text { SVA, steam plume } \\
\text { SVA, steam plume } \\
\text { SVA, steaming and phreatic ash emission } \\
\text { SVA, steam plumes } \\
\text { SVA, suspicious clouds, redistributed ash } \\
\text { SVA, anomalous clouds } \\
\text { Triggered seismicity, vapor steam plumes and redistributed ash } \\
\text { Anomalous clouds }\end{array}$ \\
\hline Sanford & $\begin{array}{l}1993 \\
1994 \\
1997 \\
2009 \\
2010\end{array}$ & $\begin{array}{l}\text { SVA, reported steam plume likely from avalanche } \\
\text { SVA, reported steam plume likely from avalanche } \\
\text { SVA, large steam cloud from SW face } \\
\text { Persistent anomalous cloud } \\
\text { Anomalous cloud }\end{array}$ \\
\hline Shrub Mud & $\begin{array}{l}1997 \\
1998 \\
1999\end{array}$ & $\begin{array}{l}\text { Eruption; energetic ejection of saline mud and } \mathrm{CO}_{2} \\
\text { Eruption continues; saline mud and } \mathrm{CO}_{2} \text { ejected } \\
\text { Eruption continues; saline mud and } \mathrm{CO}_{2} \text { emission }\end{array}$ \\
\hline Klawasi Mud & 2006 & Possible new mud vent \\
\hline Spurr & $\begin{array}{l}1992 \\
1993 \\
2004 \\
2005 \\
2006\end{array}$ & $\begin{array}{l}\text { Subplinian eruptions; ash, pyroclastic flows, lahars } \\
\text { SVA, glacial outburst produces seismicity } \\
\text { Heat flux to summit; lahars; cauldron develops } \\
\text { Continued heat to summit; cauldron evolves } \\
\text { Continued heat to summit; cauldron evolves }\end{array}$ \\
\hline
\end{tabular}


Table 4b. Compilation by volcano for particular years included in an Alaska Volcano Observatory Annual Summary, 1992-2010.-Continued

[Suspect Volcanic Activity (SVA) is defined as a report of eruption or possible eruption that is normal fumarolic activity or non-volcanic phenomena, such as weather related. Use of this term was suspended in 2006. PIREP, pilot weather report]

\begin{tabular}{|c|c|c|}
\hline Volcano & Year mentioned & Type of activity \\
\hline \multicolumn{3}{|c|}{ Alaska (east to west)—Continued } \\
\hline Redoubt & $\begin{array}{l}1992 \\
2003 \\
2007 \\
2008 \\
2009 \\
2010\end{array}$ & $\begin{array}{l}\text { SVA, steam plume from still-cooling dome } \\
\text { SVA, anomalous weather cloud } \\
\text { Possible first signs of precursory activity leading to eruption in } 2009 \\
\text { Precursory activity leading to } 2009 \text { eruption } \\
\text { Eruption, dome building/destruction, lahars, ashfall } \\
\text { Vapor and gas clouds; brief uptick in seismicity }\end{array}$ \\
\hline Iliamna & $\begin{array}{l}1992 \\
1994 \\
1996 \\
1997 \\
1999 \\
2003 \\
2005\end{array}$ & $\begin{array}{l}\text { SVA, PIREP of large steam plume, media frenzy } \\
\text { SVA, vigorous steam plume, avalanche } \\
\text { Intense seismicity related to magmatic intrusion } \\
\text { SVA; anomalous seismic swarm; avalanche } \\
\text { SVA, avalanche } \\
\text { SVA, avalanche } \\
\text { SVA, rock avalanche }\end{array}$ \\
\hline Augustine & $\begin{array}{l}1998 \\
2005 \\
2006 \\
2007\end{array}$ & $\begin{array}{l}1986 \text { dome spine partially collapses, generates mudflow } \\
\text { Precursory activity prior to eruption in early } 2006 \\
\text { Explosive and effusive eruption } \\
\text { Strong seismic events; reports of steam plumes }\end{array}$ \\
\hline Fourpeaked & $\begin{array}{l}2006 \\
2007 \\
2009 \\
2010\end{array}$ & $\begin{array}{l}\text { Phreatic eruption } \\
\text { Ongoing fumarolic emissions } \\
\text { Continued decline of steam and gas emissions } \\
\text { Decreasing fumarolic emissions, earthquake swarms }\end{array}$ \\
\hline $\begin{array}{l}\text { Katmai Group } \\
\text { Mageik } \\
\text { Martin/Mageik/Trident } \\
\text { Martin } \\
\text { Martin/Mageik/Trident/Mount Katmai } \\
\text { Martin/Mageik/Snowy/Kukak } \\
\text { Snowy } \\
\text { Snowy/Kukak } \\
\text { Martin/Mageik } \\
\text { Mageik } \\
\text { Martin } \\
\text { Martin }\end{array}$ & $\begin{array}{l}1992 \\
1994 \\
1995 \\
1996 \\
1997 \\
2000 \\
2001 \\
2002 \\
2003 \\
2004 \\
2006 \\
2010\end{array}$ & $\begin{array}{l}\text { SVA, anomalous cloud } \\
\text { SVA, plume-like cloud } \\
\text { SVA, large steam plume } \\
\text { SVA, anomalous seismicity } \\
\text { SVA, PIREPS of ash and steam plumes } \\
\text { SVA, steaming hole in glacier } \\
\text { SVA, steaming hole in glacier } \\
\text { SVA, steam plume } \\
\text { SVA, steaming, large cloud of re-suspended ash } \\
\text { SVA, large steam plume } \\
\text { Earthquake swarm } \\
\text { Re-suspended ash }\end{array}$ \\
\hline Martin/Mageik/Trident & 2005 & SVA, steam cloud, re-suspended ash, new crater? \\
\hline Becharof Lake & $\begin{array}{l}1998 \\
2010\end{array}$ & $\begin{array}{l}\text { SVA, intense seismic swarm and inflationary episode } \\
\text { Earthquake swarm }\end{array}$ \\
\hline Chiginagak & $\begin{array}{l}1997 \\
1998 \\
2000 \\
2005\end{array}$ & $\begin{array}{l}\text { Minor eruptive activity, new fumarole field } \\
\text { SVA, continuation of increased fumarolic activity } \\
\text { SVA, steam emissions from fumarole field } \\
\text { Heat to summit; acidic flood; cauldron develops }\end{array}$ \\
\hline Aniakchak & $\begin{array}{l}2005 \\
2008 \\
2009 \\
2010\end{array}$ & $\begin{array}{l}\text { SVA, anomalous seismicity, thermal anomaly } \\
\text { Weather related noise on seismic stations } \\
\text { Anomalous seismicity } \\
\text { Low frequency earthquake swarms }\end{array}$ \\
\hline
\end{tabular}


Table 4b. Compilation by volcano for particular years included in an Alaska Volcano Observatory Annual Summary, 1992-2010.-Continued

[Suspect Volcanic Activity (SVA) is defined as a report of eruption or possible eruption that is normal fumarolic activity or non-volcanic phenomena, such as weather related. Use of this term was suspended in 2006. PIREP, pilot weather report]

\begin{tabular}{|c|c|c|}
\hline Volcano & Year mentioned & Type of activity \\
\hline \multicolumn{3}{|c|}{ Alaska (east to west)—Continued } \\
\hline \multirow[t]{13}{*}{ Veniaminof } & 1993 & Low-level eruption and lava flows \\
\hline & 1994 & Strombolian eruption and lava flows \\
\hline & 1995 & Strombolian eruptions \\
\hline & 1999 & SVA, extreme discharge and turbid river \\
\hline & 2002 & Low-level phreatic eruptions \\
\hline & 2003 & Low-level phreatic eruptions \\
\hline & 2004 & Weak phreatic and Strombolian eruption \\
\hline & 2005 & Intermittent phreatic and Strombolian eruption \\
\hline & 2006 & Intermittent phreatic and Strombolian eruption \\
\hline & 2007 & Weak phreatic emissions and vapor plumes \\
\hline & 2008 & Weak phreatic emissions and vapor plumes \\
\hline & 2009 & Minor phreatic eruptions \\
\hline & 2010 & Sporadic seismicity, vapor plumes \\
\hline Kupreanof & 1994 & SVA, PIREP of unusual steam plume \\
\hline \multirow[t]{6}{*}{ Pavlof } & 1996 & Strombolian eruption \\
\hline & 1997 & Strombolian eruption concludes \\
\hline & 1999 & SVA, summit snow melt, ash dustings, steam plumes \\
\hline & 2001 & SVA, steaming, possible ash, sulfur smell \\
\hline & 2005 & SVA, mis-located steam plume \\
\hline & 2007 & Strombolian eruption \\
\hline \multirow[t]{3}{*}{ Hague (Emmons Lake Caldera) } & 2002 & SVA, increase in fumarolic activity in summit crater \\
\hline & 2003 & SVA, crater lake drains, refills, drains \\
\hline & 2005 & SVA, steam plume \\
\hline Frosty & 2001 & SVA, rock fall avalanches \\
\hline \multirow[t]{15}{*}{ Shishaldin } & 1993 & Minor phreatic \\
\hline & 1994 & SVA, PIREP of minor steam/ash \\
\hline & 1995 & Minor eruptive activity, steam/ash \\
\hline & 1996 & Eruption; steam/ash and thermal anomaly \\
\hline & 1997 & Minor eruptive activity, steam/ash \\
\hline & 1998 & Minor eruptive activity, steam/ash \\
\hline & 1999 & Strombolian eruption \\
\hline & 2000 & Minor eruptive activity, steam/ash \\
\hline & 2001 & Minor unrest, seismicity increase, steam clouds \\
\hline & 2002 & SVA, shallow seismicity; PIREP of possible eruption \\
\hline & 2003 & SVA, steam plumes \\
\hline & 2004 & Small steam and ash plumes \\
\hline & 2005 & SVA, increased seismicity, steam plumes prompt PIREPS \\
\hline & 2008 & Minor phreatic ash emission and vigorous vapor plumes \\
\hline & 2009 & Increased seismicity, small steam and ash plumes, thermal anomalies \\
\hline \multirow[t]{4}{*}{ Westdahl } & 1992 & Fissure eruption, lava fountains, ash clouds, lava flow \\
\hline & 1996 & SVA, suspicious weather cloud on satellite image \\
\hline & 2004 & SVA, seismic swarm \\
\hline & 2010 & Increase in lower crustal seismicity \\
\hline \multirow[t]{5}{*}{ Akutan } & 1992 & SVA, steam/ash emissions \\
\hline & 1996 & Intensive seismicity, ground cracking \\
\hline & 1998 & SVA, tremor-like seismicity \\
\hline & 2003 & SVA, anomalous steam plume \\
\hline & 2007 & Triggered seismicity; inflation; anomalous steaming on lower east flank \\
\hline
\end{tabular}


Table 4b. Compilation by volcano for particular years included in an Alaska Volcano Observatory Annual Summary, 1992-2010.-Continued

[Suspect Volcanic Activity (SVA) is defined as a report of eruption or possible eruption that is normal fumarolic activity or non-volcanic phenomena, such as weather related. Use of this term was suspended in 2006. PIREP, pilot weather report]

\begin{tabular}{|c|c|c|}
\hline Volcano & Year mentioned & Type of activity \\
\hline \multicolumn{3}{|c|}{ Alaska (east to west)—Continued } \\
\hline \multirow[t]{6}{*}{ Makushin } & 1993 & Minor phreatic \\
\hline & 1994 & SVA, PIREP of minor steam/ash \\
\hline & 1995 & SVA, steam plume \\
\hline & 2001 & SVA, increase in seismicity \\
\hline & 2008 & $\begin{array}{l}\text { Unalaska Bay; discolored seawater/bubbles likely due to groundwater } \\
\text { discharge; not volcanic }\end{array}$ \\
\hline & 2010 & Seismicity, anomalous clouds reported \\
\hline Bogoslof & 1992 & Dome extrusion, ash and steam emissions \\
\hline \multirow[t]{4}{*}{ Okmok } & 1997 & Strombolian eruption \\
\hline & 2001 & SVA, seismic swarm \\
\hline & 2008 & Major Phreatomagmatic eruption \\
\hline & 2009 & Bursts of tremor, inflation \\
\hline Vsevidof & 1999 & SVA, sighting of ash after regional earthquake \\
\hline \multirow[t]{9}{*}{ Cleveland } & 1994 & SVA, possible steam/ash emission \\
\hline & 1997 & Minor eruption, steam/ash \\
\hline & 2001 & Eruption; gas/ash, lava/debris flows \\
\hline & 2005 & Intermittent explosions \\
\hline & 2006 & Intermittent explosions \\
\hline & 2007 & Intermittent explosions, small ash clouds \\
\hline & 2008 & Intermittent explosions; small ash clouds \\
\hline & 2009 & Intermittent explosions, thermal anomalies, minor ash and gas emission \\
\hline & 2010 & Explosions, small ash clouds, vapor plumes, thermal anomalies \\
\hline \multirow[t]{2}{*}{ Amukta } & 1996 & Small eruption; ash emission \\
\hline & 1997 & SVA, PIREP of small ash eruption \\
\hline \multirow[t]{2}{*}{ Seguam/Pyre Peak } & 1992 & Minor eruptive activity, steam/ash emissions \\
\hline & 1993 & Fissure eruption produces lava flow and ash cloud \\
\hline \multirow[t]{2}{*}{ Kliuchef (Atka) } & 1993 & SVA, audible rumbling, strong sulfur odor \\
\hline & 1995 & SVA, large steam plume, strong sulfur odor \\
\hline \multirow[t]{5}{*}{ Korovin (Atka) } & 1996 & SVA, PIREP of ash cloud, suspicious cloud on satellite image \\
\hline & 1998 & Eruption; explosions and ash fall \\
\hline & 2005 & Minor eruption, steam and ash \\
\hline & 2006 & Seismic swarms, uplift, increased fumarolic activity \\
\hline & 2007 & Seismic swarms; continued fumarolic activity; inflation rate decreases \\
\hline \multirow[t]{4}{*}{ Kasatochi } & 2005 & SVA, unusual bubbling; floating scum on crater lake \\
\hline & 2006 & Continued bubbling in intracaldera lake \\
\hline & 2008 & Major explosive eruption \\
\hline & 2010 & Fumarolic emission, diffuse degassing, coastal erosion \\
\hline \multirow[t]{2}{*}{ Great Sitkin } & 2001 & SVA, anomalous seismicity \\
\hline & 2002 & SVA, seismic swarm, tremor \\
\hline \multirow[t]{4}{*}{ Kanaga } & 1993 & SVA, increased steaming \\
\hline & 1994 & Eruption; steam/ash and lava flow \\
\hline & 1995 & Minor eruptive activity, steam/ash and lava \\
\hline & 1996 & Possible eruption and ash emission \\
\hline Tanaga & 2005 & SVA, anomalous seismicity, including a period of tremor \\
\hline
\end{tabular}


Table 4b. Compilation by volcano for particular years included in an Alaska Volcano Observatory Annual Summary, 1992-2010.-Continued

[Suspect Volcanic Activity (SVA) is defined as a report of eruption or possible eruption that is normal fumarolic activity or non-volcanic phenomena, such as weather related. Use of this term was suspended in 2006. PIREP, pilot weather report]

\begin{tabular}{|c|c|c|}
\hline Volcano & Year mentioned & Type of activity \\
\hline \multicolumn{3}{|c|}{ Kamchatka and northern Kurile Islands (north to south) } \\
\hline \multirow[t]{14}{*}{ Sheveluch } & 1997 & Dome extrusion \\
\hline & 1998 & Lava dome growth \\
\hline & 1999 & Lava dome growth and collapse, ash \\
\hline & 2000 & Lava dome growth, ash \\
\hline & 2001 & Lava dome growth and collapse, ash \\
\hline & 2002 & Lava dome growth, ash, pyroclastic flows \\
\hline & 2003 & Lava dome growth, ash, pyroclastic flows, lahar \\
\hline & 2004 & Lava dome growth, pyroclastic flows, lahars, ash \\
\hline & 2005 & Lava dome growth, dome collapse, pyroclastic flows, ash \\
\hline & 2006 & Lava dome growth, dome collapse, explosions \\
\hline & 2007 & Lava dome growth, dome collapse, explosions \\
\hline & 2008 & Lava dome growth, dome collapse, explosions \\
\hline & 2009 & Lava dome growth, explosions, pyroclastic flows, ash plumes, ash fall \\
\hline & 2010 & Lava dome growth, dome collapse, explosions \\
\hline \multirow[t]{15}{*}{ Klyuchevskoy } & 1996 & Gas/ash eruption \\
\hline & 1997 & Gas/ash eruption \\
\hline & 1998 & Gas/ash eruption \\
\hline & 1999 & Gas/ash eruption \\
\hline & 2000 & Vulcanian explosions \\
\hline & 2001 & Fumarolic plume \\
\hline & 2002 & Elevated seismicity, gas-rich explosion \\
\hline & 2003 & Elevated seismicity, ash explosion, Strombolian activity \\
\hline & 2004 & Elevated seismicity \\
\hline & 2005 & Strombolian eruption, lava flows, lahars \\
\hline & 2006 & Increased seismicity, thermal anomaly, no eruption \\
\hline & 2007 & Ash emission, Strombolian lava fountaining, lava flows \\
\hline & 2008 & Strombolian lava fountaining, lava flows, lahars, phreatic explosions \\
\hline & 2009 & Strombolian, Vulcanian activity, lava flow production, ash falls \\
\hline & 2010 & Strombolian lava fountaining, explosions, lava flows, lahars \\
\hline \multirow[t]{16}{*}{ Bezymianny } & 1995 & Explosive eruption \\
\hline & 1996 & Lava extrusion \\
\hline & 1997 & Dome collapse and explosive eruption \\
\hline & 1998 & Degassing and spalling of new dome \\
\hline & 1999 & Degassing and spalling of new dome, ash \\
\hline & 2000 & Dome growth, explosive eruption \\
\hline & 2001 & Accelerated dome growth, pyroclastic flows \\
\hline & 2002 & Accelerated dome growth, explosions, pyroclastic flows \\
\hline & 2003 & Dome growth and explosive collapse \\
\hline & 2004 & Minor explosive eruptions, gas and steam emissions \\
\hline & 2005 & Dome growth continues, two explosive episodes \\
\hline & 2006 & Dome growth continues, two explosive episodes \\
\hline & 2007 & Intermittent lava dome growth and explosions \\
\hline & 2008 & Intermittent lava dome growth and explosion, ash cloud in August \\
\hline & 2009 & $\begin{array}{l}\text { Short-lived explosions, hot avalanches, pyroclastic flows, lava flow, ash } \\
\text { plumes and clouds, ash falls }\end{array}$ \\
\hline & 2010 & Dome growth continues, ash explosion \\
\hline \multirow[t]{2}{*}{ Kizimen } & 2009 & Increased seismicity and fumarolic activity; no eruption \\
\hline & 2010 & Explosive eruption, ash clouds, pyroclastic flows, lava flow \\
\hline
\end{tabular}


Table 4b. Compilation by volcano for particular years included in an Alaska Volcano Observatory Annual Summary, 1992-2010.-Continued

[Suspect Volcanic Activity (SVA) is defined as a report of eruption or possible eruption that is normal fumarolic activity or non-volcanic phenomena, such as weather related. Use of this term was suspended in 2006. PIREP, pilot weather report]

\begin{tabular}{|c|c|c|}
\hline Volcano & Year mentioned & Type of activity \\
\hline \multicolumn{3}{|c|}{ Kamchatka and northern Kurile Islands (north to south)_C Continued } \\
\hline \multirow[t]{16}{*}{ Karymsky } & 1995 & Increased seismicity \\
\hline & 1996 & Explosive eruption \\
\hline & 1997 & Low level Strombolian eruptions \\
\hline & 1998 & Low level Strombolian eruptions \\
\hline & 1999 & Low level Vulcanian and Strombolian eruptions \\
\hline & 2000 & Low level Vulcanian and Strombolian eruptions \\
\hline & 2001 & Low level Vulcanian and Strombolian eruptions \\
\hline & 2002 & Low level Vulcanian and Strombolian eruptions, explosions, avalanches \\
\hline & 2003 & Vulcanian and Strombolian eruptions intensify \\
\hline & 2004 & Low level Vulcanian and Strombolian eruptions \\
\hline & 2005 & Low level Vulcanian and Strombolian eruptions, explosions, lava, ash fall \\
\hline & 2006 & Low level Vulcanian and Strombolian eruptions \\
\hline & 2007 & Low level Vulcanian and Strombolian eruptions \\
\hline & 2008 & Low level Vulcanian and Strombolian activity \\
\hline & 2009 & Strombolian/Vulcanian eruption continues intermittently \\
\hline & 2010 & Strombolian/Vulcanian eruption continues intermittently \\
\hline \multirow[t]{2}{*}{ Koryaksky } & 2008 & Phreatic explosions and ash emission \\
\hline & 2009 & Increased fumarolic output, phreatic explosions \\
\hline \multirow[t]{3}{*}{ Avachinsky } & 1996 & Increased seismicity \\
\hline & 2001 & Increased seismicity, phreatic explosion \\
\hline & 2005 & Increased seismicity, thermal anomalyies \\
\hline \multirow[t]{4}{*}{ Gorely } & 2007 & Increased seismicity; uncertain source \\
\hline & 2008 & Increased seismicity; uncertain source and fumarolic activity at Gorely \\
\hline & 2009 & Increased fumarolic activity and seismicity, no eruption \\
\hline & 2010 & Increased seismicity, thermal output, degassing \\
\hline \multirow[t]{5}{*}{ Mutnovsky } & 1996 & Fumarolic plume \\
\hline & 2000 & Gas and steam explosion \\
\hline & 2005 & Increased fumarolic activity \\
\hline & 2007 & Increased seismicity- source uncertain; fumarolic activity at Gorely \\
\hline & 2008 & Increased seismicity- source uncertain; fumarolic activity at Gorely \\
\hline \multirow[t]{2}{*}{ Alaid (Kurile Islands) } & 1996 & Ash plume \\
\hline & 1997 & SVA \\
\hline \multirow[t]{3}{*}{ Ebeko } & 2005 & Increased fumarolic activity and phreatic eruptions \\
\hline & 2006 & Increased fumarolic activity \\
\hline & 2009 & Increased fumarolic output, small phreatic eruptions \\
\hline \multirow[t]{4}{*}{ Chikurachki } & 2003 & Stombolian and Vulcanian eruption, ash fall \\
\hline & 2005 & Brief explosion produces ash and ash fall \\
\hline & 2007 & Brief explosion produces ash cloud and ash fall \\
\hline & 2008 & Explosions and limited ash clouds \\
\hline Severgin & 2006 & Phreatic or fumarolic activity \\
\hline Chirinkotan & 2004 & Brief, low-level steam, gas, and ash emission \\
\hline Ekarma & 2010 & Phreatic eruption, lahar \\
\hline Raikoke & 2009 & Fumarolic emission and possible phreatic ash \\
\hline Sarychev & 2009 & Significant explosive eruption; ash clouds, pyroclastic and lava flows \\
\hline \multirow{2}{*}{ Berga } & 2006 & Phreatic or fumarolic activity \\
\hline & 2007 & Possible eruption or gas outburst \\
\hline Tyatya & 2008 & Possible increase in fumarolic activity \\
\hline
\end{tabular}


Table 4c. Citations for Alaska Volcano Observatory Annual Summary reports, 1992-2010.

\begin{tabular}{|c|c|}
\hline Year & Citation \\
\hline 1992 & $\begin{array}{l}\text { McGimsey, R.G., Neal, C.A., and Doukas, M.P., 1995, Volcanic activity in Alaska: } \\
\text { Summary of events and response of the Alaska Volcano Observatory 1992: U.S. } \\
\text { Geological Survey Open-File Report 95-83, } 26 \text { p. }\end{array}$ \\
\hline
\end{tabular}

1993 Neal, C.A., McGimsey, R.G., and Doukas, M.P., 1996, 1993 Volcanic activity in Alaska: Summary of events and response of the Alaska Volcano Observatory: U.S. Geological Survey Open-File Report 96-24, 21 p.

1994 Neal, C.A., Doukas, M.P., and McGimsey, R.G., 1995, 1994 Volcanic activity in Alaska: Summary of events and response of the Alaska Volcano Observatory: U.S. Geological Survey Open-File Report 95-271, 20 p.

1995 McGimsey, R.G., and Neal, C.A., 1996, 1995 Volcanic activity in Alaska and Kamchatka: Summary of events and response of the Alaska Volcano Observatory: U.S. Geological Survey Open-File Report 96-738, 22 p.

1996 Neal, C.A., and McGimsey, R.G., 1997, 1996 Volcanic activity in Alaska and Kamchatka: Summary of events and response of the Alaska Volcano Observatory: U.S. Geological Survey Open-File Report 97-433, 34 p.

1997 McGimsey, R.G., and Wallace, K.L., 1999, 1997 Volcanic activity in Alaska and Kamchatka: Summary of events and response of the Alaska Volcano Observatory: U.S. Geological Survey Open-File Report 99-448, 42 p.

1998 McGimsey, R.G., Neal, C.A., and Girina, Olga, 2003, 1998 Volcanic activity in Alaska and Kamchatka: Summary of events and response of the Alaska Volcano Observatory: U.S. Geological Survey Open-File Report 03-423, 35 p.

1999 McGimsey, R. G., Neal, C. A., and Girina, Olga, 2004a, 1999 Volcanic activity in Alaska and Kamchatka: Summary of events and response of the Alaska Volcano Observatory: U.S. Geological Survey Open-File Report OF 2004-1033, 49 p.

2000 Neal, C.A., McGimsey, R.G., and Chubarova, Olga, 2004, 2000 Volcanic activity in Alaska and Kamchatka: Summary of events and response of the Alaska Volcano Observatory: U.S. Geological Survey Open-File Report 2004-1034, 37 p.

2001 McGimsey, R.G., Neal, C.A., and Girina, Olga, 2004b, 2001 Volcanic activity in Alaska and Kamchatka: Summary of events and response of the Alaska Volcano Observatory: U.S. Geological Survey Open-File Report 2004-1453, 57 p.

2002 Neal, C.A., McGimsey, R.G., and Girina, Olga, 2005, 2002 Volcanic activity in Alaska and Kamchatka: Summary of events and response of the Alaska Volcano Observatory: U.S. Geological Survey Open-File Report 2004-1058, 55 p.

2003 McGimsey, R.G., Neal, C.A., and Girina, Olga, 2005, 2003 Volcanic activity in Alaska and Kamchatka: Summary of events and response of the Alaska Volcano Observatory: U.S. Geological Survey Open-File Report 2005-1310, 62 p.

2004 Neal, C.A., McGimsey, R.G., Dixon, J.P., and Melnikov, Dmitry, 2005, 2004 Volcanic activity in Alaska and Kamchatka: Summary of events and response of the Alaska Volcano Observatory: U.S. Geological Survey Open-File Report 2005-1308, 71 p.

2005 McGimsey, R.G., Neal, C.A., Dixon, J.P., Ushakov, Sergey, 2007, 2005 Volcanic activity in Alaska, Kamchatka, and the Kurile Islands: Summary of events and response of the Alaska Volcano Observatory: U.S. Geological Survey Scientific Investigations Report 2007-5269, 94 p.

2006 Neal, C.A., McGimsey, R.G., Dixon, J.P., Manevich, Alexander, and Rybin, Alexander, 2009, 2006 Volcanic activity in Alaska, Kamchatka, and the Kurile Islands: Summary of events and response of the Alaska Volcano Observatory: U.S. Geological Survey Scientific Investigations Report 2008-5214, 102 p.

2007 McGimsey, R.G., Neal, C.A., Dixon, J.P., Malik, Nataliya, and Chibisova, Marina, 2011, 2007 Volcanic activity in Alaska, Kamchatka, and the Kurile Islands: Summary of events and response of the Alaska Volcano Observatory: U.S. Geological Survey Scientific Investigations Report 2010-5242, 110 p. 
Table 4c. Citations for Alaska Volcano Observatory Annual Summary reports, 1992-2010.-Continued

\begin{tabular}{|c|c|c|}
\hline Year & Citation & URL \\
\hline 2009 & $\begin{array}{l}\text { McGimsey, R.G., Neal, C.A., Girina, O.A., Chibisova, Marina, and Rybin, } \\
\text { Alexander, 2013, } 2009 \text { Volcanic activity in Alaska, Kamchatka, and the Kurile } \\
\text { Islands: Summary of events and response of the Alaska Volcano Observatory: } \\
\text { U.S. Geological Survey Scientific Investigations Report 2013-5213, } 125 \text { p. }\end{array}$ & http://pubs.usgs.gov/sir/2013/5213/ \\
\hline 2010 & $\begin{array}{l}\text { Neal, C.A., Herrick, J., Girina, O., Chibisova, M., Rybin, A., McGimsey, R., and } \\
\text { Dixon, J., 2013, } 2010 \text { Volcanic activity in Alaska, Kamchatka, and the Kurile } \\
\text { Islands: Summary of events and response of the Alaska Volcano Observatory: } \\
\text { U.S. Geological Survey Scientific Investigations Report 2014-5034, } 76 \text { p. }\end{array}$ & http://pubs.usgs.gov/sir/2014/5034/ \\
\hline
\end{tabular}




\title{
Volcanic Activity in Alaska, Northeast To Southwest Along Aleutian Arc
}

\author{
Wrangell Volcano \\ CAVW\# 1105-02 \\ $62^{\circ} 00^{\prime} \mathrm{N} 145^{\circ} 01^{\prime} \mathrm{W}$ \\ $4,317 \mathrm{~m}(14,163 \mathrm{ft})$

\section{REPORTS OF INCREASED VAPOR EMISSION FROM THE SUMMIT} \\ New lidar image of a portion of the summit
}

No eruptive activity or significant unrest occurred at Wrangell in 2010. However, AVO received an interesting new image of the summit region as well as a report of possible vapor emission from the summit area.

In May 2010, a single lidar swath over the summit of Wrangell (fig. 2) was flown by UAFGI glaciologists Paul Claus and Chris Larsen. The resulting processed image depicts the topography of North Crater, a long-known fumarolic source on the northwestern rim of the ice-filled summit caldera (fig. 3). The characteristic higher northern and lower southeastern rim of the crater is clear in a cross section of the lidar derived topography (fig. 4). Within North Crater, there are several secondary depressions including a complex, kidney-bean shaped pit about $20 \mathrm{~m}$ (65 ft) deep and $200 \mathrm{~m}$ (660 ft) across, located in the center of the crater. This result is broadly consistent with previously recorded surveys of North Crater using photogrammetric techniques (Benson and others, 2007, fig. 6).

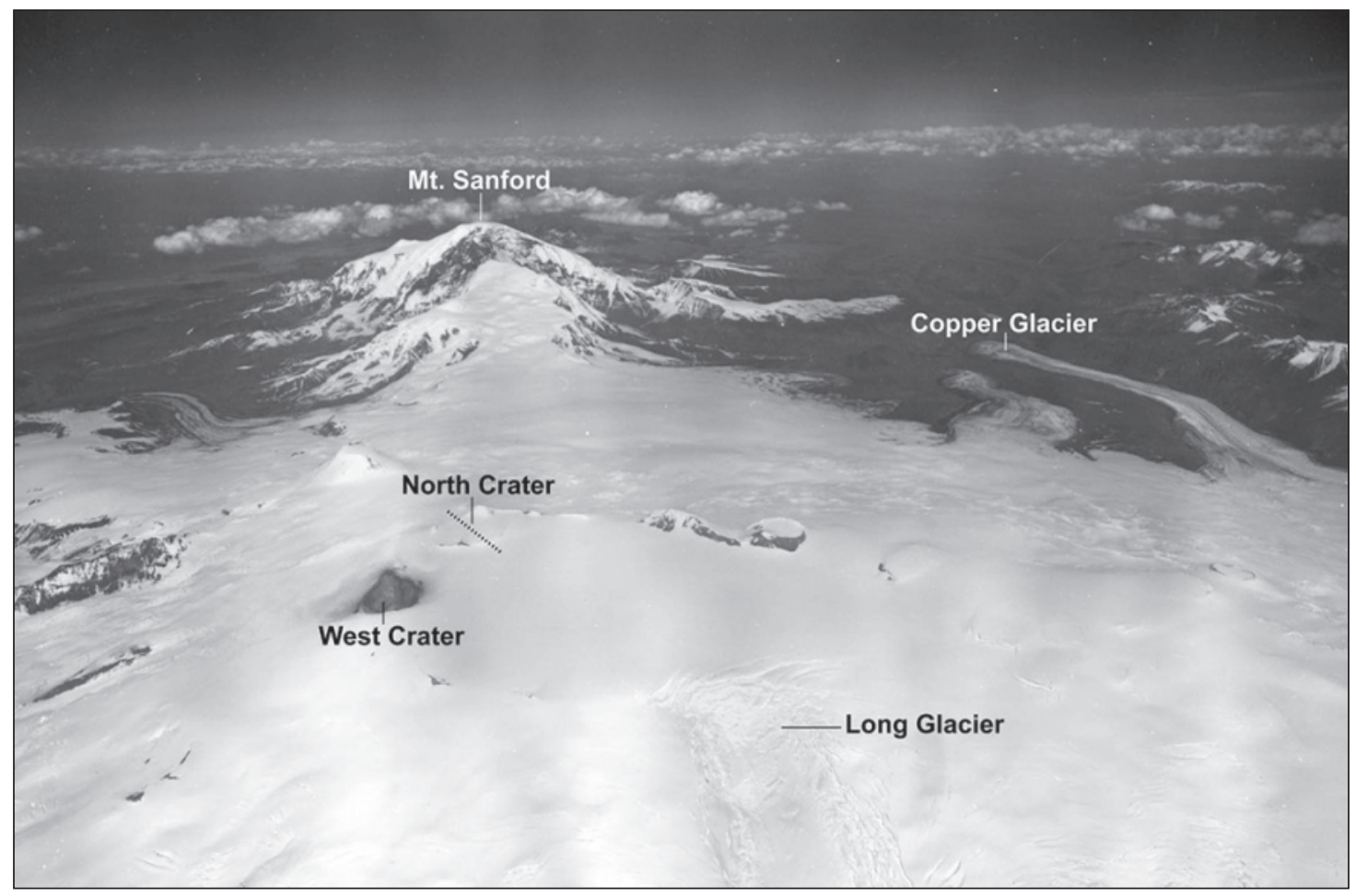

Figure 2. Oblique aerial photograph of the summit of Wrangell volcano, north at the top, June 15, 1948. U.S. Air Force image from figure 1 of Benson and others (2007). Approximate cross section shown in figure 4 is shown by black dashed line. Steep exposed rocky face of Sanford visible in the distance (see fig. 7) 


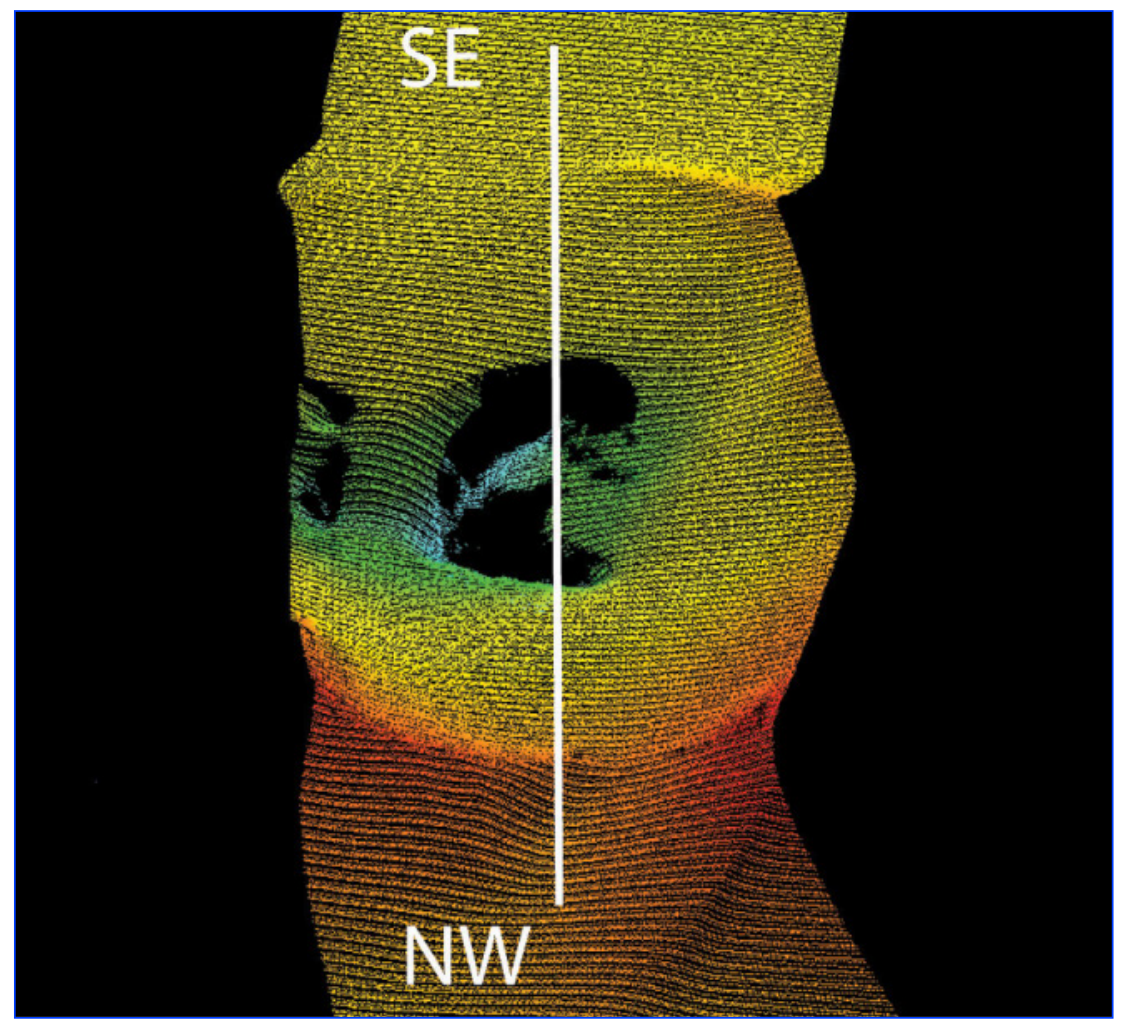

Figure 3. Lidar image of the summit of Wrangell volcano. Single swath is $450 \mathrm{~m}$ $(1,480 \mathrm{ft})$ wide and oriented southeast (top) to northwest (bottom). The instrument used to collect these data is a Riegl ${ }^{\circledR}$ LMS-0240i Pulsed Scanning Laser Altimeter. This $904 \mathrm{~nm}$ wavelength laser records (at $10,000 \mathrm{~Hz}$ ) a swath of surface elevations roughly $550 \mathrm{~m}(1,800 \mathrm{ft})$ wide from $500 \mathrm{~m}(1,640 \mathrm{ft})$ above ground level (AGL) over snow and ice with a density of one point per meter squared. Image and caption courtesy Chris Larsen, UAFGI.

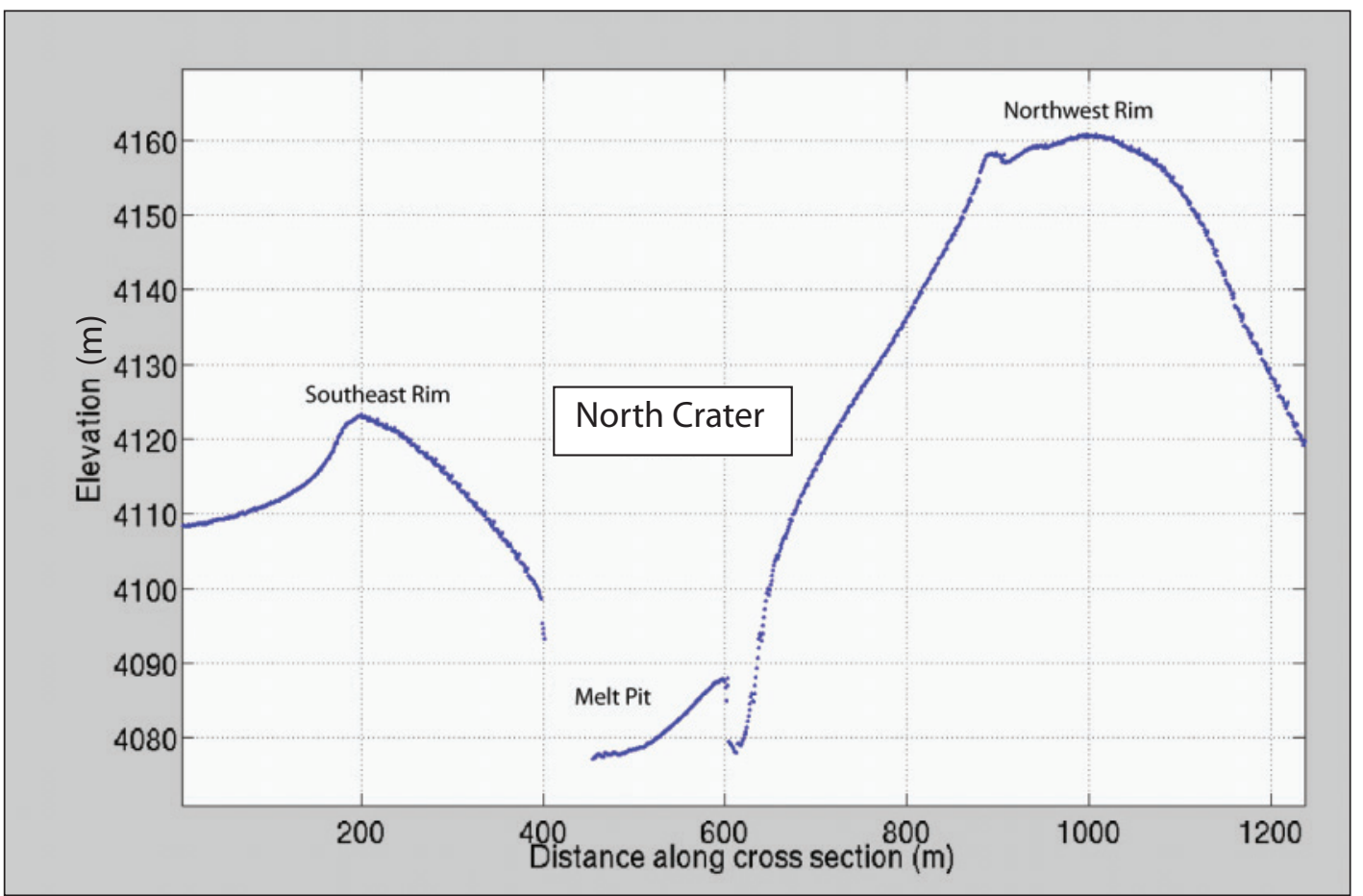

Figure 4. Cross section from southeast to northwest along the center track of the lidar swath over North Crater at the summit of Wrangell volcano. Image and caption courtesy Chris Larsen, UAFGI. 
In early November, a long-time resident from the Copper River valley called AVO to report "more activity at the Mount Wrangell summit than he had ever seen before.” He sent AVO several images of the volcano taken on November 2 (fig. 5). The observer reported that when the activity in question began, there had been no weather clouds in the area. He noted about ten 'bursts' from the summit and said this was unusual compared to the typical steady emissions often seen above the volcano. AVO reviewed available seismic and satellite data and, finding no evidence of volcanic signals, concluded that the phenomenon was most likely weather related.

Mount Wrangell is a massive, glacier-covered volcano in the Wrangell-St. Elias National Park and Preserve of eastern Alaska (fig. 1; Richter and others, 1995). Three geothermally active craters occur on the eastern and western rims of the ice-filled $4 \times 6 \mathrm{~km}(2.5 \times 3.7 \mathrm{mi})$ summit crater, historically the source of nearly constant fumarolic emission (Benson and others, 2007). Resultant vapor plumes can be quite vigorous and sometimes reach hundreds of meters (thousands of feet) above ground level, occasionally entraining fine fragmental debris and producing localized deposits of dark material on the ice. This, in addition to wind redistribution of debris from the summit area, is often mistaken for eruptive activity. AVO maintains a short period seismic network of four stations, however, station outages due to harsh winter conditions and difficult access are common. In addition to these data, AVO relies on local observers, pilots, and satellite imagery to track activity at the volcano. Except for a vigorous steam and occasional phreatic ash emission, no historical magmatic eruptions are known to have occurred (Richter and others, 1995). A 'lava flow' eruption reported in 1902 is dubious.

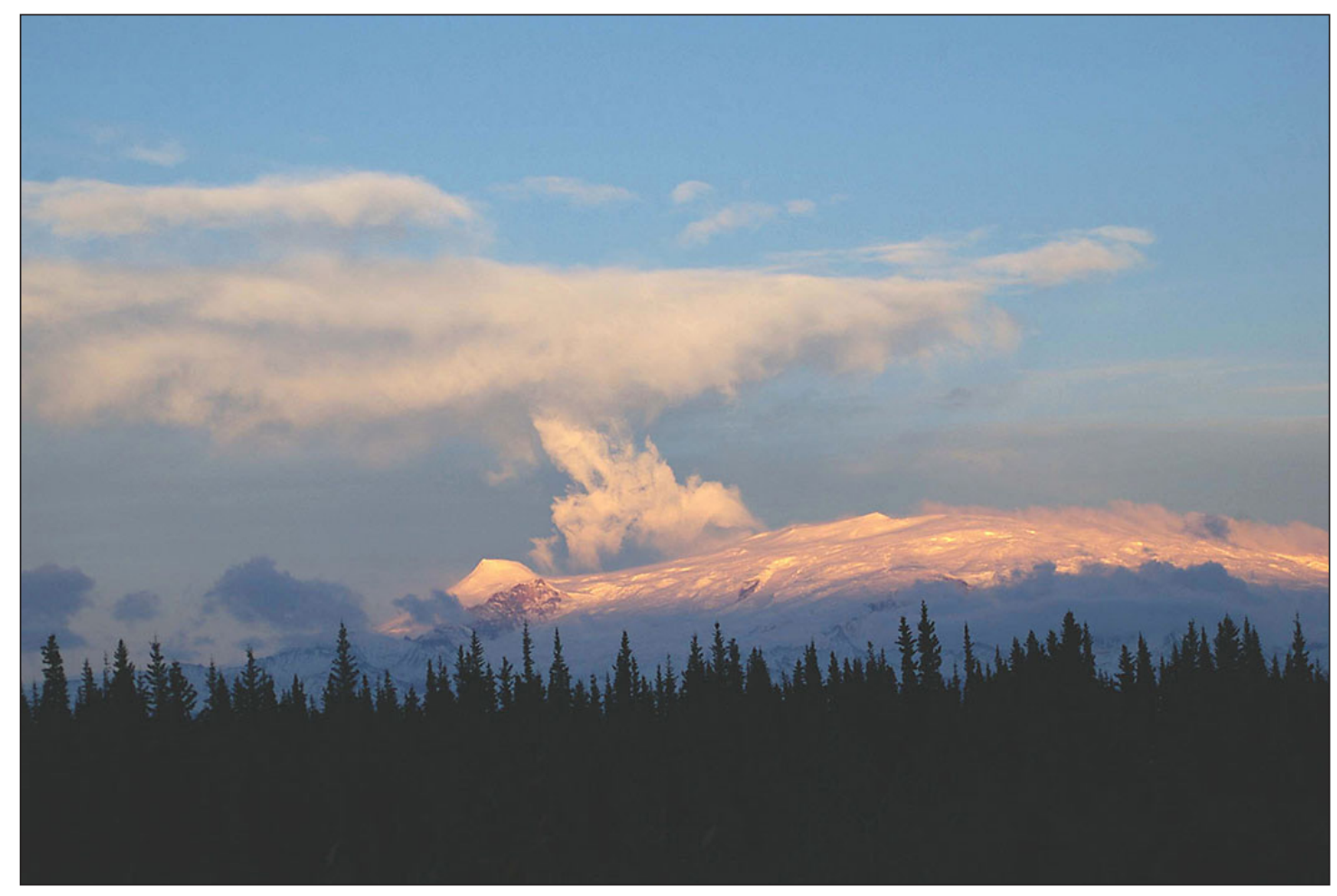

Figure 5. Suspect cloud over summit of Wrangell volcano. Photograph by C.D. McCurry, November 2, 2010, used with permission. 


\section{Mount Sanford Volcano}

CAVW\# 1105-01

$62^{\circ} 13^{\prime} \mathrm{N} 144^{\circ} 08^{\prime} \mathrm{W}$

$4,949 \mathrm{~m}(16,237 \mathrm{ft})$

Copper River Basin

\section{LARGE VAPOR CLOUD RISING FROM THE SOUTHERN FACE}

Unusual cloud originating at Sanford

Mount Sanford, the highest of the westernmost Wrangell field volcanoes, is a massive, glacially dissected, complex Pleistocene stratovolcano. Typically over the course of a year, AVO receives several calls regarding possible plumes arising from the summit or the steep southern face of the mountain; 2010 was no exception.
On March 23, a consulting geologist working in the area reported seeing a 'good size plume' from Sanford on 2 nights. A number of Copper River Valley residents shared photographs of Sanford from March 15 when a dramatic looking plume emanated from the southern flank and summit of the volcano (fig. 6 ).

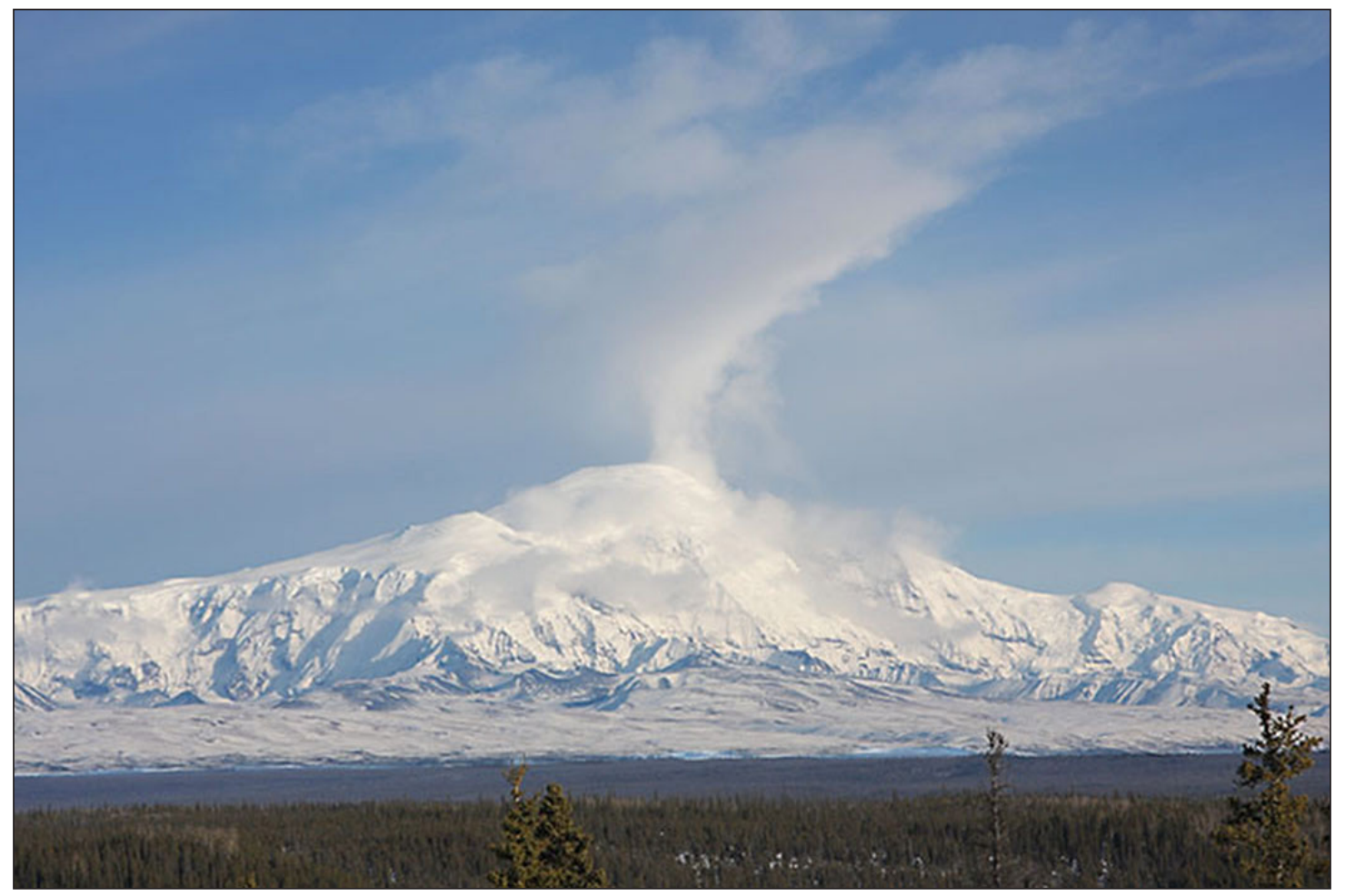

Figure 6. Cloud from Mount Sanford. Photograph by S. McCarthy, March 15, 2010, used with permission. AVO database image at URL: http://www.avo.alaska.edu/images/image. $p h p ? i d=19558$. 
A similar cloud was reported on October 20 by Pete Dalton, District Ranger for the National Park Service, stationed at the Gulkana Airport (fig. 7). According to Pete Dalton, the plume rose about 2,000 to 3,000 ft above the summit. AVO received multiple calls regarding the October 20 plume, which appeared to originate from several points on the near-vertical, rocky southern face of the volcano. A towering vapor cloud emanating from the steep rocky face of this dissected volcano has been reported before (McGimsey and others, 1999) and may be related to rock and ice-fall activity, solar warming of the rock and ice face, or a combination of processes. No features related to volcanic heat sources have been documented on Mount Sanford; however, no comprehensive thermal survey has been done.
Mount Sanford, located $45 \mathrm{mi}$ (72 km) east of Glennallen, Alaska, is a large, glacier-covered, complex, Pleistocene andesite shield volcano in the Wrangell-St. Elias National Park and Preserve of eastern Alaska (Richter and others, 1995). At $16,237 \mathrm{ft}(4,949 \mathrm{~m})$, Sanford is the second highest volcano in the entire Wrangell volcanic field. The southwestern face is a shear wall with vertical relief of $8,000 \mathrm{ft}$ (about 2,400 m), and is the site of almost constant rock-, snow-, and ice-falls onto the Sanford Glacier, activity which on occasion is energetic enough to produce anomalous steam plumes (Neal and others, 1995, 1996; McGimsey and Wallace, 1999). There is no record of historical eruptive activity at Mount Sanford, and the youngest lava flows are estimated to be 100,000 years old (Richter and others, 1995).

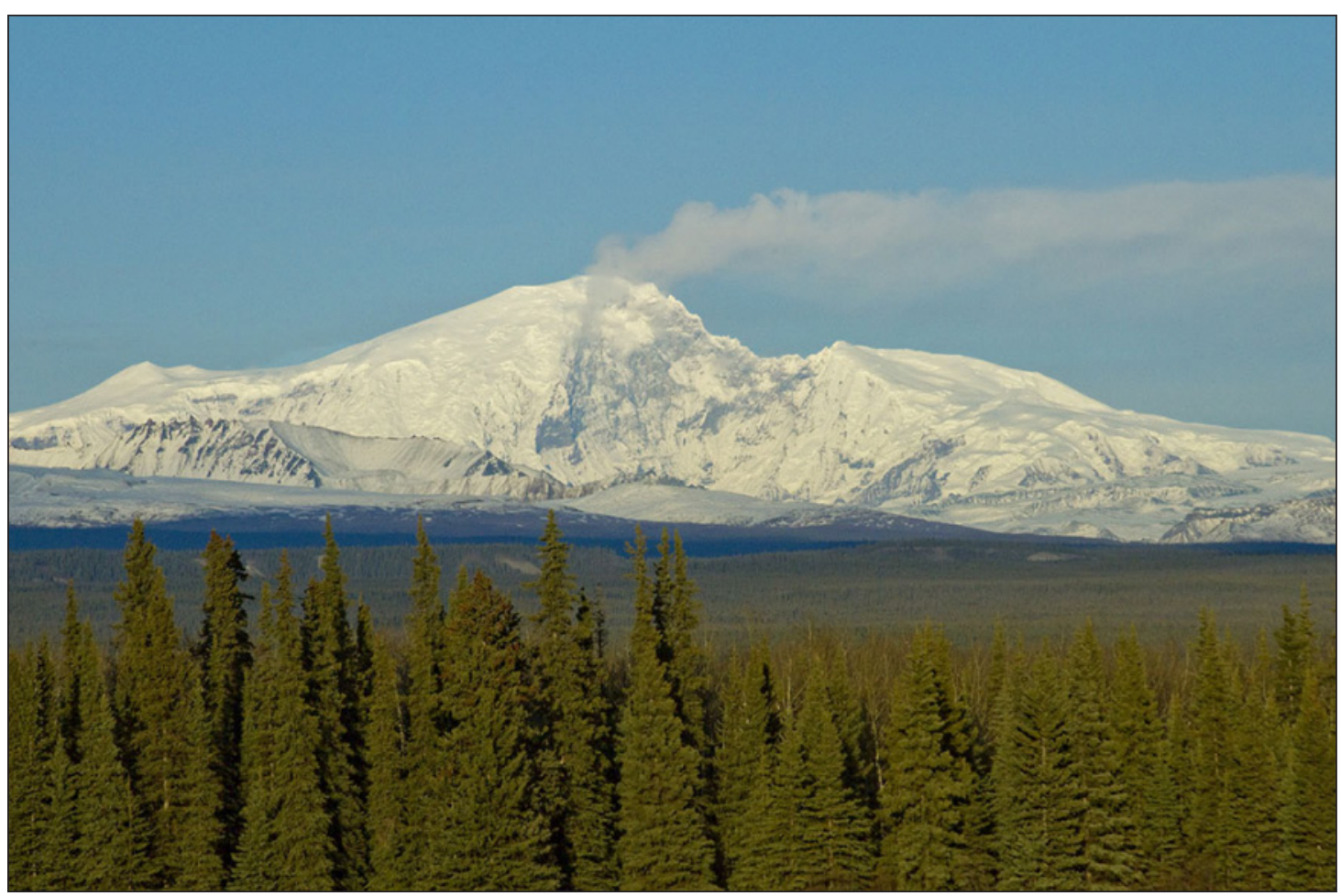

Figure 7. Cloud from Mount Sanford as viewed looking north from mile 5.5 of the Old Edgerton Highway in Kenny Lake, Alaska. Photograph by P. Boos, October 20, 2010, used with permission. AVO database image at URL: http://www.avo.alaska.edu/images/image.php? id=31642. 


\title{
Redoubt Volcano
}

\author{
CAVW\# 1103-03
}

$60^{\circ} 29^{\prime} \mathrm{N} 152^{\circ} 45^{\prime} \mathrm{W}$

$3,108 \mathrm{~m}(10,197 \mathrm{ft})$

Cook Inlet

\section{COOLING 2009 LAVA DOME; CONTINUED DEGASSING}

Redoubt's activity in 2010 was dominated by slowly diminishing unrest related to the aftermath of the 2009 eruption (Schaefer, 2012; McGimsey and others, 2013). AVO staff conducted a variety of field instrumentation maintenance and scientific investigations related to the 2009 eruption; results are summarized in a special issue of the Journal of Volcanology and Geothermal Research published in 2013 (Bull and Buurman, 2013).

Throughout the year, the penultimate 2009 andesitic lava dome in the summit crater produced frequently visible plumes of water vapor and volcanic gas. Thermal anomalies on satellite images related to the cooling dome were detected intermittently and the AVO low light camera north of the crater documented changing areas of incandescence on the dome surface. Elevated $\mathrm{SO}_{2}$ and $\mathrm{CO}_{2}$ continued to be measured above and downwind of the lava dome for the entire year (Werner and others, 2012).

The volcano began the year at Aviation Color Code and Volcano Alert Level YELLOW/ADVISORY; with no evidence of continuing eruptive activity and steadily decreasing seismicity, AVO reverted to GREEN/NORMAL on January 5. Frequent plume sightings led to a number of citizen reports of activity at Redoubt. During the weekend of January 23, residents and a local radio station on the Kenai Peninsula reported a plume. On the same day, incandescence was detected from the lava dome by AVO's low light camera at Juergen's hut (a scientific observation station established in 1990 by Juergen Kienle, a UAFGI geophysicist) on the ridge just north of the volcano. Numerous calls on January 25 from residents as well as the Federal Aviation Administration described an especially vigorous plume. This heightened concern was likely due to the effect of backlighting conditions that often makes a dominantly water vapor plume appear dark and ashy. Such plumes were not accompanied by increases in seismicity or elevated temperatures detected by satellite or the low light camera. Two tremor events were recorded in late January, but with no clear association to visible changes at the volcano.

An uptick in seismicity prompted AVO to raise the Aviation Color Code and Volcano Alert Level from GREEN/ NORMAL to YELLOW/ADVISORY on April 5. An approximate 10 minute long tremor-like signal on April 4 was followed by drumbeat-like seismic signals on station RSO. These repeating earthquakes with similar waveforms occurring once or twice per minute may have reflected renewed lava motion in the conduit, lava effusion, repeated pressurization and depressurization within the shallow conduit, ice creep, or other processes.

Robust plumes drifting downwind at the approximate altitude of the summit were observed on April 6-8. Seen during overflights on April 8-9, the lava dome was covered by snow and there was no evidence of any recent melting or flowage events. A voluminous steam and gas plume rose from the top of the dome (fig. 8). The top of the dome was obscured but there were clear views of prominent and persistently active fumaroles on the eastern and western sides. The inner summit crater walls as well as the upper Crescent Glacier (on the southwestern flank of the volcano) was discolored with pinkish debris interpreted as windblown ash from the surface of the dome or rockfalls off the dome. Debris from recent rockfalls from the crater walls also was observed. Both $\mathrm{SO}_{2}$ (measured with COSPEC) and $\mathrm{CO}_{2}$ values were lower in early April than on December 13, 2009. Decreasing gas emission was consistent with shallow degassing of the stagnant lava dome and upper conduit and no recharge by new magma from depth. Under certain wind conditions, the ongoing gas emission produced a visible haze over Cook Inlet; in early May, AVO received photographs from Nikiski showing a layer of discoloration stretching from the volcano nearly to Homer, $110 \mathrm{~km}$ (68 mi) southeast of the volcano.

By April 12, seismicity had decreased to near background levels and AVO returned the volcano to GREEN/NORMAL. However, continued bursts of seismicity, especially visible on station RSO high on the volcano's southern flank, were recorded later in April. The origin of these small, repetitive, high-energy events remains unclear and may include ice or rockfall processes. Additional swarms of high frequency events at several kilometers depth, occasional long period events, and bursts of tremor continued into the summer.

In June, in cooperation with Italian collaborators from the INGV (Instituto Nazionale di Geofisica e Vulcanologia), AVO installed a field sensor to monitor $\mathrm{SO}_{2}$ and $\mathrm{CO}_{2}$ emissions on the western rim of Redoubt. Four times per day the station sampled $\mathrm{CO}_{2}$ and $\mathrm{SO}_{2}$; data were stored onsite and also downloaded daily via a radio link through AVO seismic station DFR. The station operated through August when it was retrieved from the rim before fall snow began. 


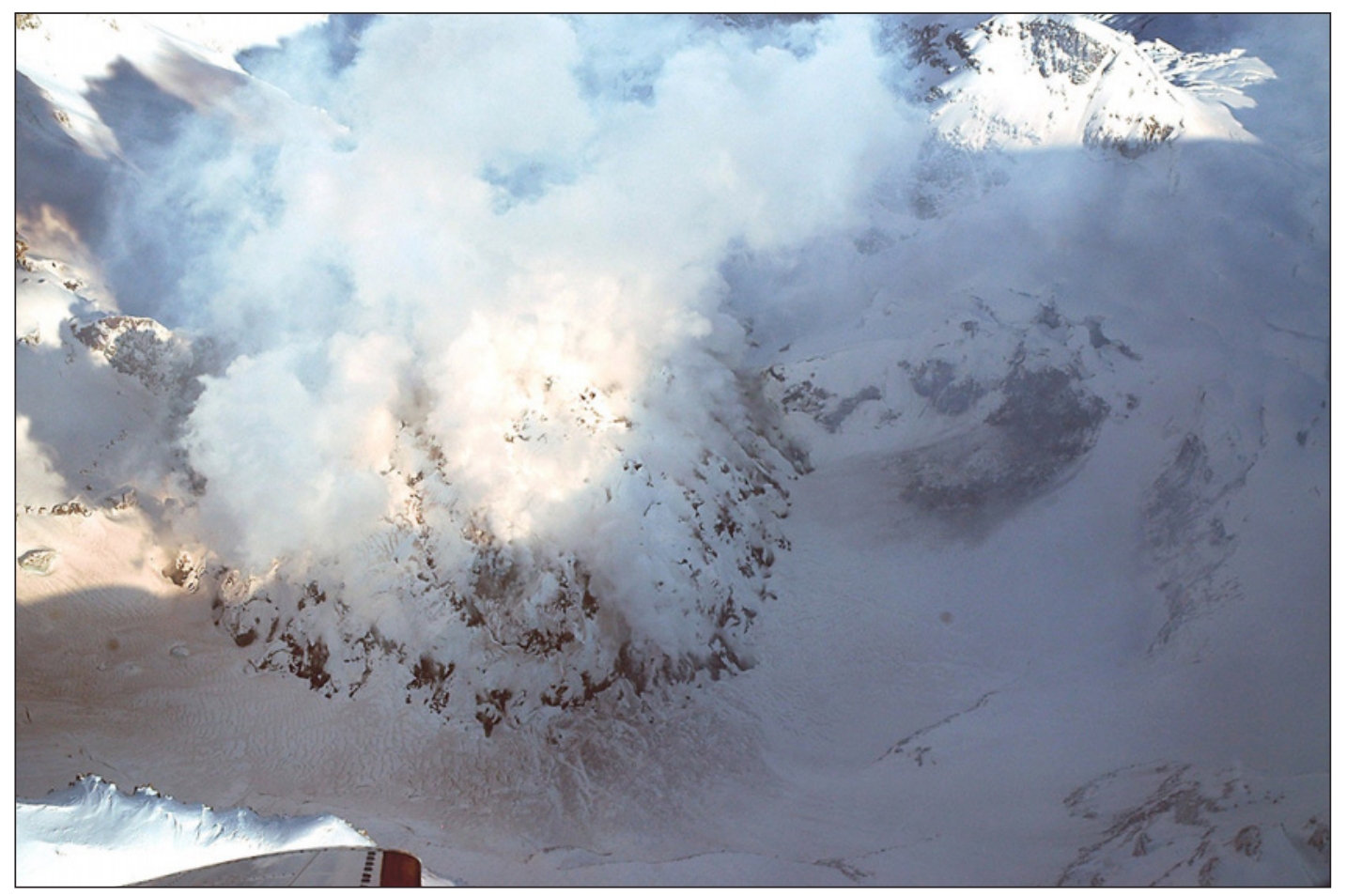

Figure 8. Aerial view of the cooling 2009 lava dome at Redoubt Volcano. In this image, north and the head of the Drift glacier gorge is at the top, obscured by fume. Note pinkish-brown dune pattern and patches atop crater snow and ice surrounding the dome, inferred to be wind-blown dust and oxidized debris from the dome surface and surrounding crater walls. A recent mixed rock and snow/ice avalanche deposit and scar is visible emanating from the summit crater wall to the right of the dome; this region appeared to be a persistently active avalanche producer in 2010. The dome width in this view is about $500 \mathrm{~m}$ (1,640 ft). Photograph by Theresa Taylor, USGS, April 9, 2010. AV0 database image at URL: http:// www.avo.alaska.edu/images/image.php?id=19597.

On July 21, an exceptionally clear day in south-central Alaska, a local air carrier reported an eruption at Redoubt at 09:29 AKDT. This pilot report apparently triggered several more reports of a large white plume at Redoubt. Analysis of seismic, satellite, and radar data showed no activity of concern.

AVO scientists and collaborators conducted a variety of field studies at Redoubt during the summer of 2010 (figs. 9-10). Readers are referred to summaries by Schaefer (2012) and McGimsey and others (2013) and special issue of the Journal of Volcanology and Geothermal Research for results from this work (Bull and Buurman, 2013).

Fall and winter at Redoubt saw continuing but decreasing rates of mostly shallow ( $<5 \mathrm{~km}$ or $3 \mathrm{mi}$ ) seismicity. Several rockfall events were recorded but there were no major avalanches or collapses of the new lava dome, despite its perch on the steep upper Drift gorge. Vapor and gas plumes above the dome continued to be captured by AVO web cameras and pilots reported occasional sulfur smells downwind of the volcano.

Heavily ice-mantled Redoubt Volcano is located on the western side of Cook Inlet, $170 \mathrm{~km}$ (106 mi) southwest of Anchorage and 82 km (51 mi) west of Kenai, within Lake Clark National Park and Preserve. Redoubt is a stratovolcano with a reported summit elevation of 3,108 m (10,197 ft) ASL. Prior to 2009, recent eruptions occurred in 1902, 1966-68, 1989-90 (Waythomas and others, 1997). The 1989-90 and 2009 eruptions produced mudflows, or lahars, that traveled down the Drift River and partially flooded the Drift River Oil Terminal facility. The 1966-68 eruption also produced lahars down the Drift River. Ash clouds produced by the 1989-90 and 2009 eruptions affected air traffic and resulted in minor or trace amounts of ash on communities in south-central Alaska (Miller and Chouet, 1994; Schaefer, 2012). 


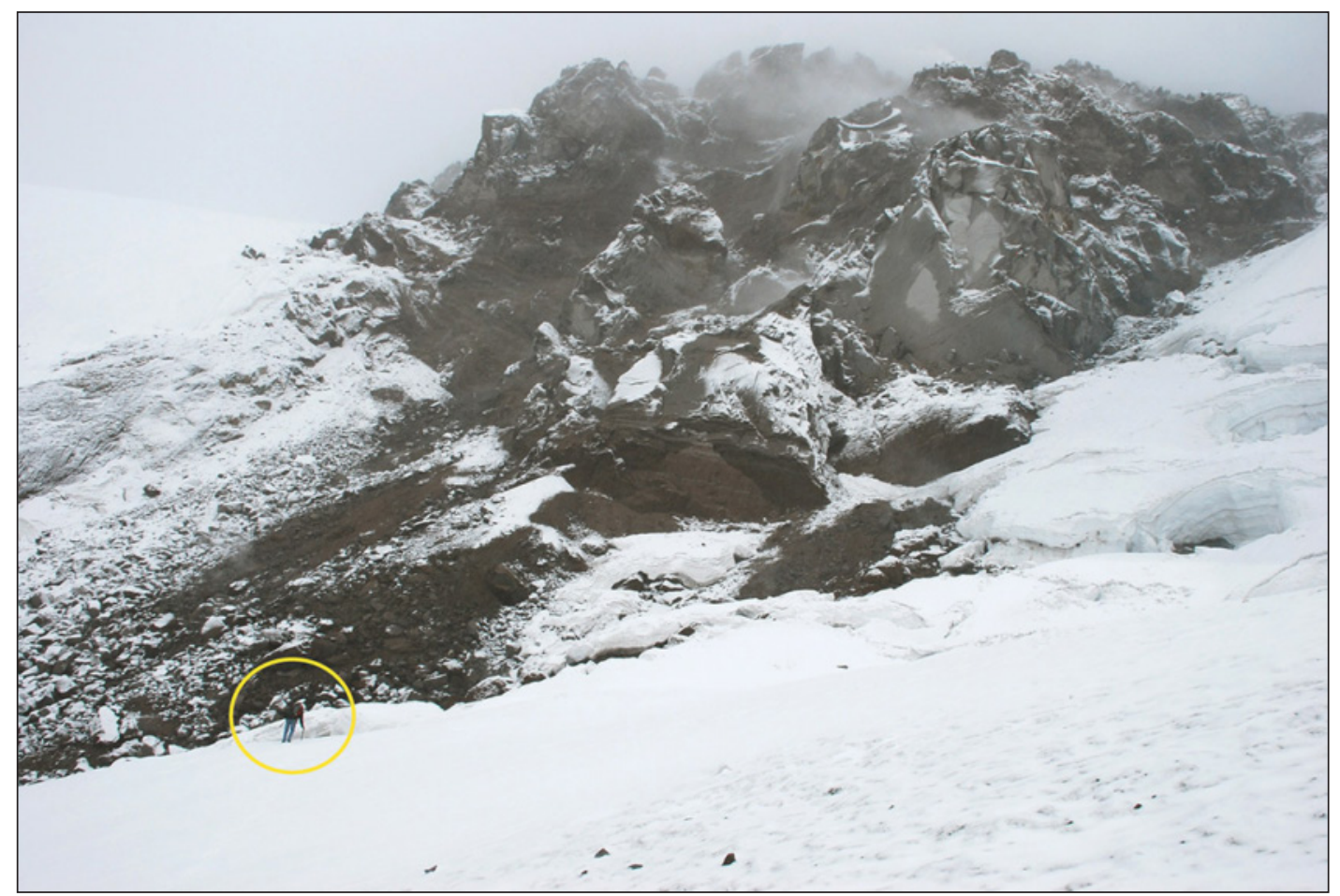

Figure 9. Geologist Steve Anderson (circled) approaches the toe of the Redoubt lava dome. Photograph by Kate Bull, AVO/ADGGS, August 22, 2010. AVO database image at URL: http://www.avo.alaska.edu/ images/image.php? id=27432.

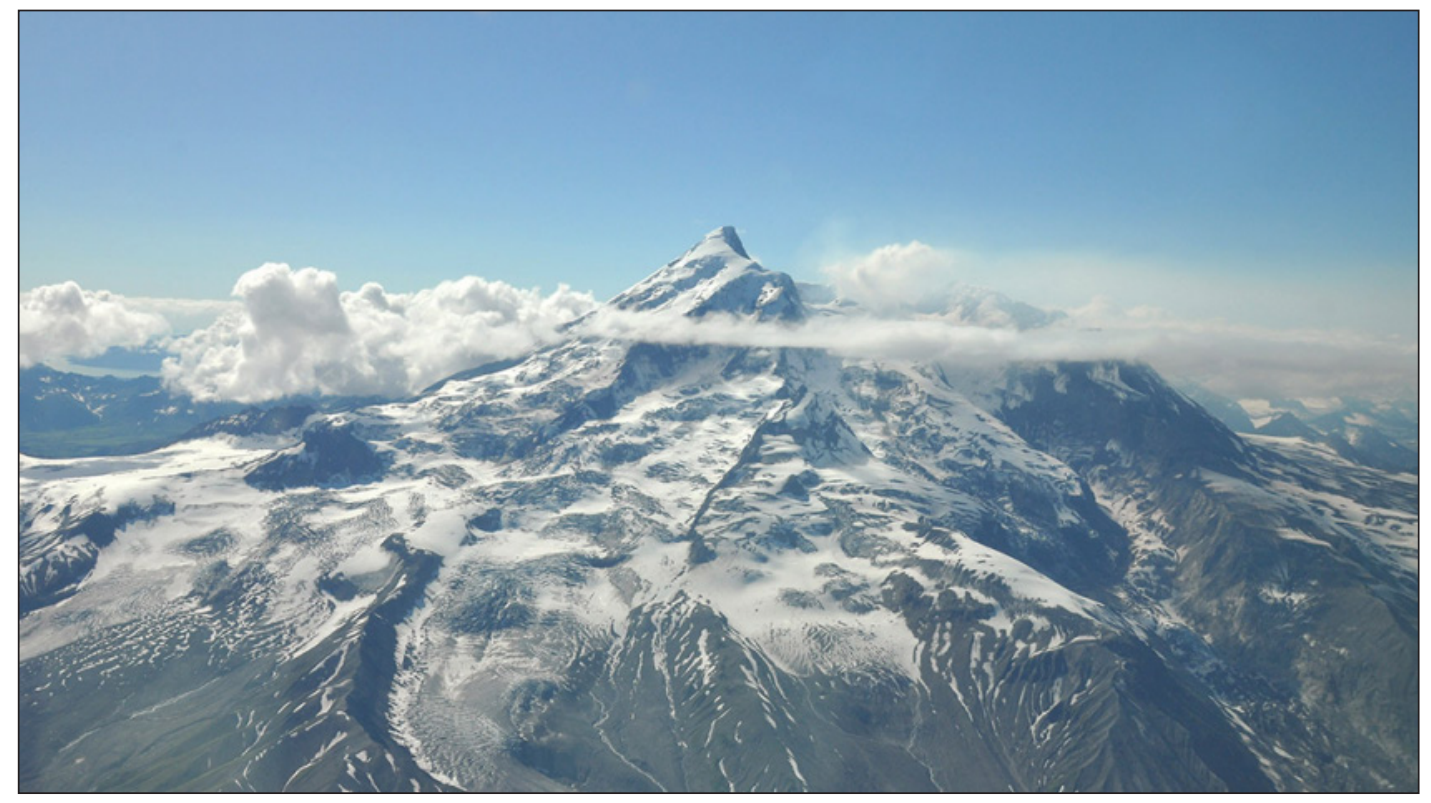

Figure 10. Oblique aerial view of Redoubt Volcano. A gas plume trails downwind to the northwest and the Drift glacier gorge is visible as the cleft in the volcano flank at right. Gray mantle on glacial ice and snowfields on the middle slopes of the volcano reflects 2009 volcanic ash emerging from the summer melt season. View is to the southwest. Photograph by Laura Kelly, USGS/AV0, August 20, 2010. AV0 database image at URL: http://www.avo.alaska.edu/images/image.php? id=27842. 


\title{
Fourpeaked Volcano
}

\author{
CAVW\# 1102-26 \\ $58^{\circ} 46^{\prime} \mathrm{N} 153^{\circ} 40^{\prime} \mathrm{W}$ \\ 2,104 m (6,903 ft) \\ Cook Inlet/Alaska Peninsula
}

\section{MINOR SEISMIC SWARMS; DWINDLING GAS EMISSIONS}

Following the 2006 phreatic eruption of Fourpeaked (Neal and others, 2009b), gas and heat flux diminished and the vents on the northern flank of the volcano gradually filled with snow and ice (McGimsey and others, 2013). Despite scattered seismic station outages in 2010, clusters of earthquakes were recorded at Fourpeaked in May, October, November, and December. A particularly notable earthquake swarm occurred on May 26 when 12 events were recorded by the Alaska Earthquake Information Center (AEIC); one of the located events occurred about $5 \mathrm{~km}$ (3 mi) west-northwest of the volcano summit at a depth of approximately $15 \mathrm{~km}(9 \mathrm{mi})$, a location similar to the swarm associated with the eruption in September 2006 (Gardine and others, 2011).
AVO supported two overflights of Fourpeaked Mountain on April 9 and June 21. The June flight was partly in response to the May 26 seismic swarm. Both flights reported continued vapor emission from a single point source, a small hole in glacier ice high on the northwestern flank (fig. 11) in the location of the 2006 vents. During both flights, magmatic gas flux was below detection (C. Werner, USGS, unpub. data.) Photograph comparisons between June 2010 and November 2009 indicated a continued decline in the strength of fumarolic output; snowfall had further buried the 2006 phreatic explosion craters blanketing the vent area and glacial outburst deposits downstream.

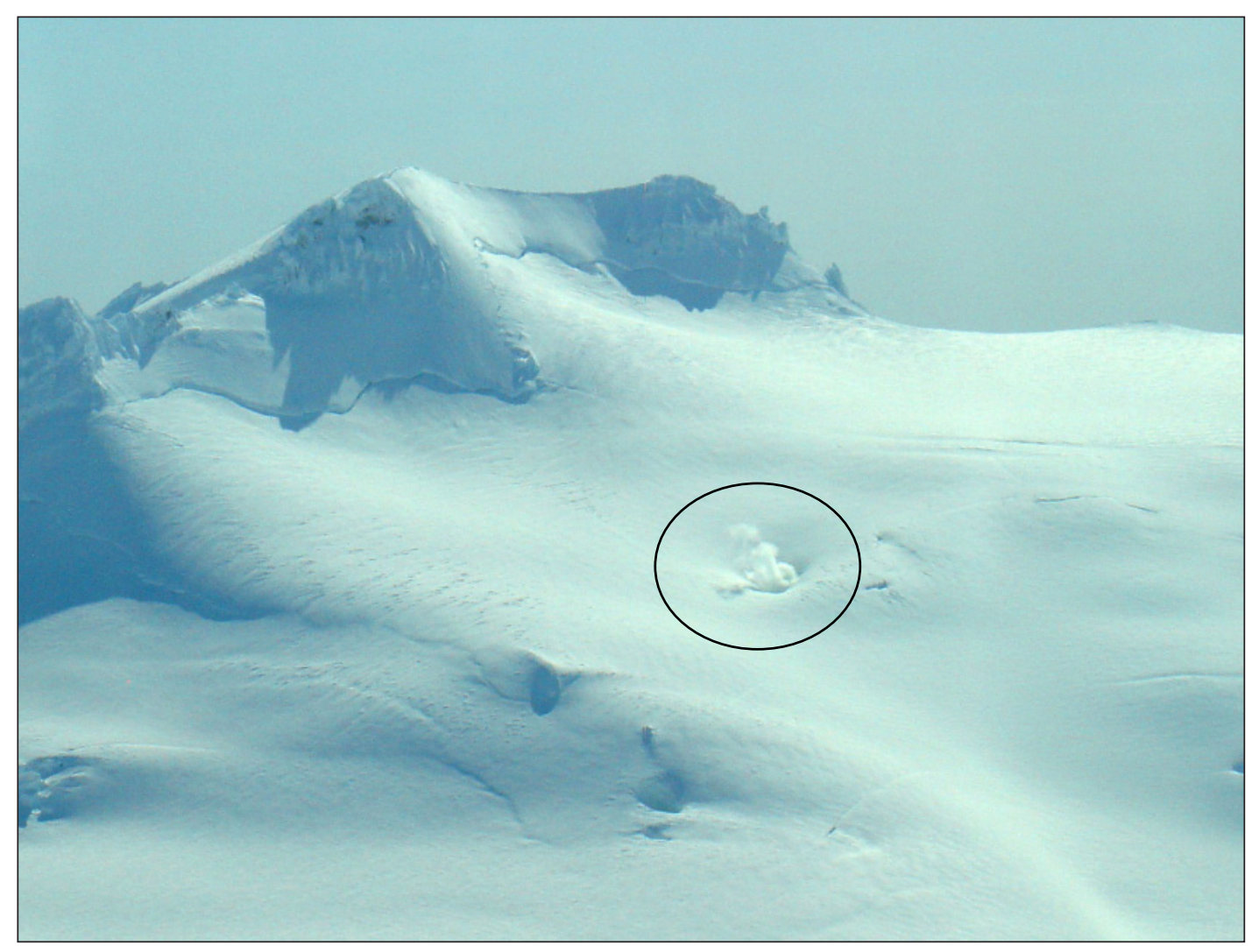

Figure 11. Aerial view of the northwestern flank of Fourpeaked. Note small wisp of vapor from a hole through the glacier ice (circled). Photograph by Peter Kelly, USGS/AVO, April 9, 2010. AVO database image at URL: http://www.avo.alaska.edu/images/image.php? id=20521. 
On October 26, a pilot observed lightning from the direction of Fourpeaked and AVO was contacted to evaluate the report. According to the pilot, the lightning lasted for about 2 hours and yet no thunder was heard. No sign of volcanic activity in any other data stream and the existence of a strong storm cell in the area indicated a likely meteorological origin for the lightning.

Other than a recollection of steaming in 1965

(information shared with AVO by a local resident in 2006), Fourpeaked is not known to have erupted historically until the 2006 phreatic explosion described in Neal and others (2009b) and Gardine and others (2011). The age of the last magmatic eruption is not known but is thought to be pre-Holocene (J. Fierstein, U.S. Geological Survey, oral commun., 2006). The range of sizes and styles of past eruptions are not well constrained; however, past eruptions of andesite and dacite indicate that eruptions of Fourpeaked can be explosive, possibly producing plumes that reach in excess of $10 \mathrm{~km}$ (33,000 ft) ASL and local ash fall and lahars. Fourpeaked lies within the northeastern corner of Katmai National Park and Preserve on the Alaska Peninsula, $7.5 \mathrm{mi}(12 \mathrm{~km})$ southwest of Mount Douglas. The volcanic edifice consists of small, isolated exposures of lava along ridge crests and cliff faces that radiate out from the ice-covered summit. 


\section{Katmai Group (Novarupta)}

CAVW\# 1102-18

$58^{\circ} 16^{\prime} \mathrm{N} 155^{\circ} 10^{\prime} \mathrm{W}$

$841 \mathrm{~m}(2,759 \mathrm{ft})$

Alaska Peninsula

\section{RESUSPENDED ASH FROM THE 1912 IGNIMBRITE AND ASH FALL DEPOSIT}

The immense pyroclastic eruption of Novarupta in 1912 produced the Valley of Ten Thousand Smokes and blanketed much of the surrounding countryside with many feet of friable, mobile, fine-grained volcanic ash (Hildreth and Fierstein, 2000). During strong winds, especially in the spring and fall, significant quantities of surface material from this 1912 deposit is lofted high into the atmosphere and carried downwind as a plume of ash. This phenomenon poses a hazard to local aviation and can result in dustings of ash on communities in Kodiak (Hadley and others, 2004).

In 2010, resuspended Novarupta ash was reported twice by the Anchorage Volcanic Ash Advisory Center. On September 27 and again on November 29, the ash cloud and its snow-free source area was well-imaged by the MODIS satellite (fig. 12). When detected or reported, the National Weather Service typically issues a SIGMET to advise air traffic of the potential hazard.

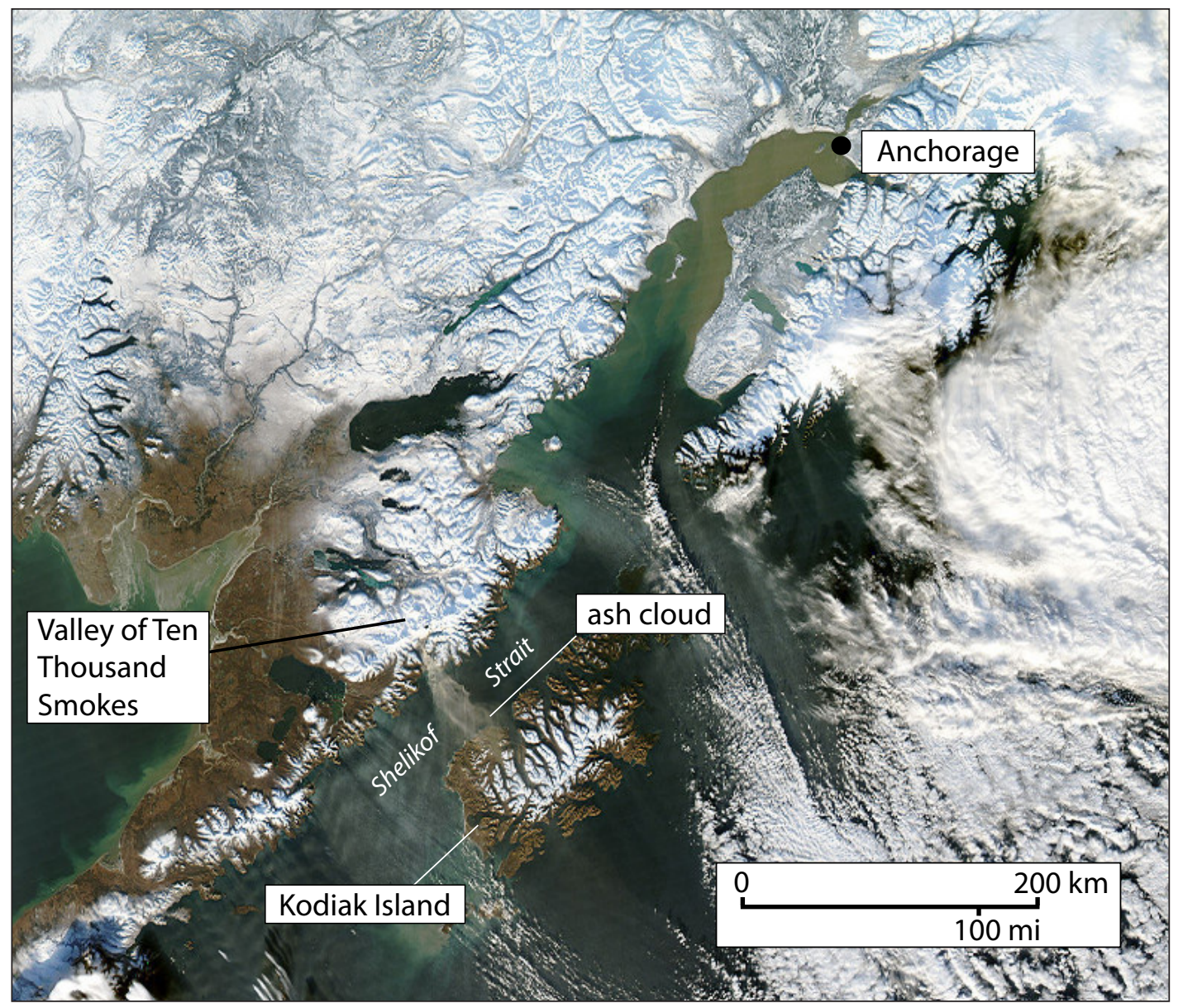

Figure 12. MODIS Aqua $1 \mathrm{~km}$ true color satellite image showing resuspended volcanic ash cloud (arrow) generated from high winds scouring exposed ash on the Pacific side of the Katmai volcanic range. The cloud stretches across the Shelikof Straight and western Kodiak Island. Image ID 2010333 taken November 29, 2010. Courtesy NASA. See fig. 1 for location of the swarm on the Alaska Peninsula. 


\section{Becharof Lake Area}

10-20 km (6-12 mi)

Northwest of Ukinrek Maars

Alaska Peninsula

\section{EARTHQUAKES NEAR GAS ROCKS}

After several years of relative seismic quiet, a flurry of earthquakes occurred in the vicinity of Peulik Volcano and Becharof Lake on the Alaska Peninsula during the first 2 weeks of June 2010 (fig. 13). The largest event of the swarm was a magnitude 5.3 that occurred the week of June 16 near the western end of Becharof Lake. This event and associated aftershocks were in the general region of the 1998 Becharof swarm, deformation, and degassing event (Lu and others, 2002; McGimsey and others, 2003).

Earthquakes continued in this region through the remainder of 2010. Unlike the 1998 swarm, there was no apparent surface deformation (Lu and others, 2002). As in 1998, AVO considered the possibility that these swarms were precursory to a 1977 Ukinrek Maars-type eruption (Kienle and others, 1980).

Becharof Lake is located on the Alaska Peninsula $80 \mathrm{~km}$ (50 mi) south of the Bristol Bay community of King Salmon. Historically active Peulik Volcano rises above the southeastern shore of the lake. The Ukinrek Maars formed in
1977 about $1.5 \mathrm{~km}$ (1 mi) south of Becharof Lake and $12 \mathrm{~km}$ (7.5 mi) northwest of Peulik. Other remnants of monogenetic phreatomagmatic volcanism dot the area (Hildreth and others, 2007). Another prominent feature on the southern shore of Becharof Lake, about $3.2 \mathrm{~km}$ (2 mi) north of Ukinrek Maars, is Gas Rocks, a rocky volcanic promontory with vigorously degassing $\mathrm{CO}_{2}$ vents along the lakeshore and in shallow water immediately offshore (Symonds and others, 1997). The lake sits atop the northeast-southwest trending Bruin Bay Fault, which is inferred to continue south and west of Gas Rocks and the Ukinrek Maars (Detterman and others, 1987).

The 1998 seismic swarm began on May 8 and continued through mid-June (Lu and others, 2002; McGimsey and others, 2003). The initial event of the swarm sequence was a ML 5.2 earthquake felt strongly in nearby communities. Overflights of the area within days of the swarm onset noted small scale slumps and sediment plumes in the lake that may have been caused by ground shaking. No other changes at either Gas Rocks or Peulik Volcano were noted. 


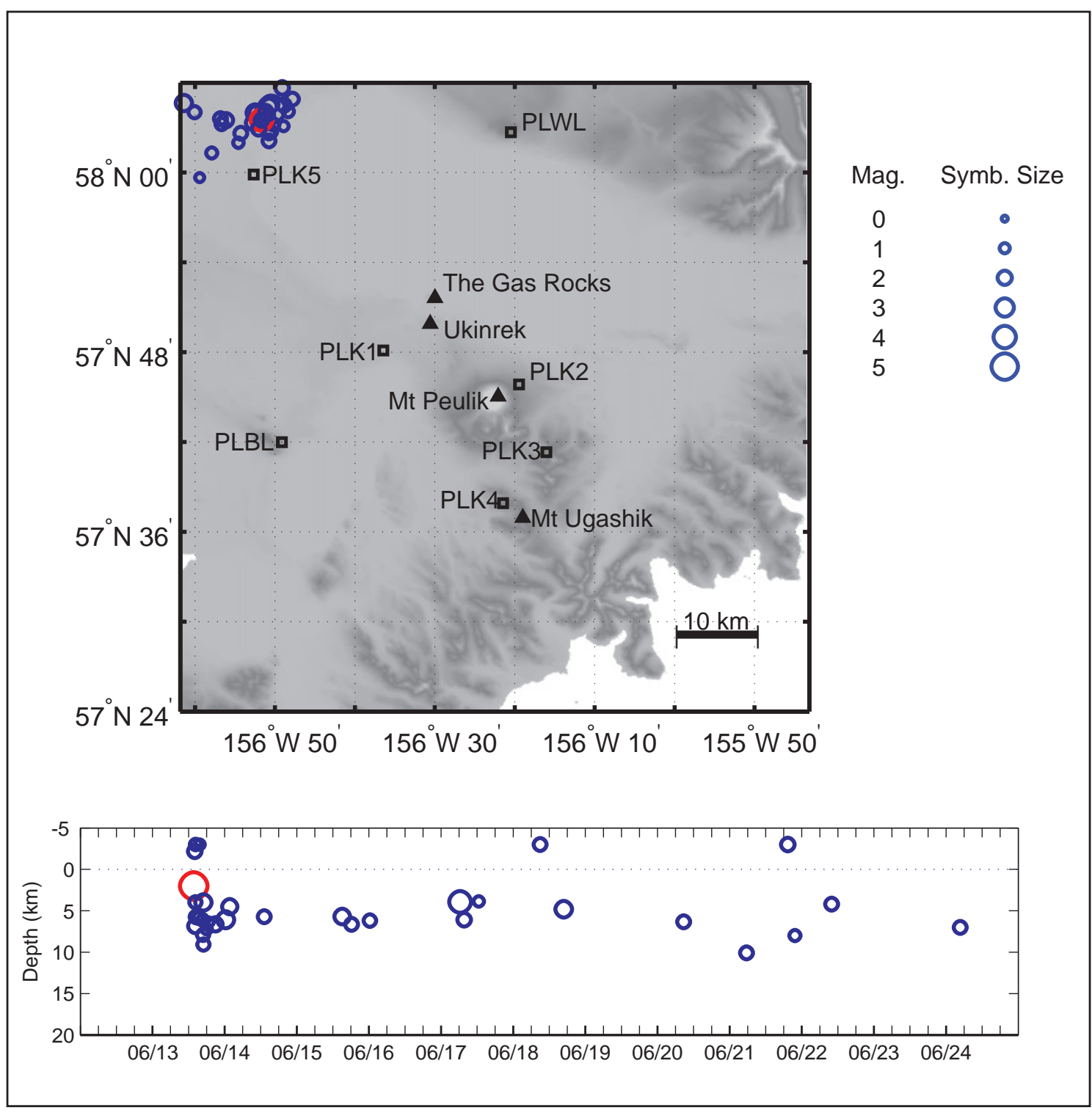

Figure 13. The Becharof swarm is the largest earthquake swarm since the Ugashik-Peulik seismograph network was installed in 1994. The largest earthquake, $M L=5.3$, is shown in red. Small blue circles are epicenters of earthquakes during the 2010 swarm that started on June 13 and lasted 11 days. Triangles are locations of volcanic centers. Open squares are seismic stations. 


\section{Aniakchak Volcano \\ CAVW\# 1102-09 \\ $56^{\circ} 54^{\prime} \mathrm{N} 158^{\circ} 13^{\prime} \mathrm{W}$ \\ $1,341 \mathrm{~m}(4,400 \mathrm{ft})$ \\ Alaska Peninsula \\ CONTINUING BURSTS OF LOW FREQUENCY EARTHQUAKES}

A low-frequency event followed by a short-lived tremorlike signal was recorded January 15 on station ANPB. There were no other stations recording data to facilitate further analysis; winters are particularly hard on Aniakchak stations and by January 26, all seismic stations were offline. On July 7, after summer maintenance and repair, two stations (ANPB and ANPK) recorded an approximate 15-minute long swarm. Another brief sequence of low-frequency events was recorded on station ANON on August 7 from about 21:20 to 21:28 UTC (fig. 14). From about 21:28 to 21:35 UTC, a signal resembling tremor occurred, although it also could be interpreted as a series of closely spaced, low-frequency events. This signal was picked up by the other five stations in the Aniakchak network.

On October 14 from about 22:29 to 22:39 UTC, another sequence of low-frequency events occurred in the Aniakchak area. Only one event could be located, about $6 \mathrm{~km}(4 \mathrm{mi})$ eastnortheast of Vent Mountain, the most prominent intracaldera cone. Another similar although shallower (9.1 km or $5.6 \mathrm{mi})$, low-frequency sequence also occurred on October 19. This event was located about $2 \mathrm{~km}$ (1.2 mi) south-southeast of Vent Mountain with a local magnitude of 0.5 .
Clustered, low-frequency events occurred on November 5, December 16, and from December 22-24. These small, emergent events may have been related to ice processes in the vicinity of the seismic station (H. Buurman, University of Alaska, written commun., 2010).

Aniakchak is a circular caldera $10 \mathrm{~km}(6.2 \mathrm{mi})$ in diameter and as deep as $1 \mathrm{~km}(3,280 \mathrm{ft})$ from the rim to the caldera floor. The caldera formed during a catastrophic eruption of some $75 \mathrm{~km}^{3}\left(18 \mathrm{mi}^{3}\right)$ of material about 3,400 years ago (Miller and Smith, 1987; Dreher and others, 2005). Numerous lava domes, lava flows, and scoria cones occupy the interior of the caldera (Neal and others, 2000); the largest intracaldera cone is Vent Mountain, $2.5 \mathrm{~km}$ (1.5 mi) in diameter and rising $430 \mathrm{~m}(1,410 \mathrm{ft})$ above the floor of the caldera. The only historical eruption of Aniakchak, a powerful explosive event that covered a large portion of the eastern Alaska Peninsula with ash, occurred in 1931 (Nicholson and others, 2011). Isolated low-frequency events beneath Aniakchak are not uncommon in the history of seismic monitoring of this young, explosive volcano (for example, McGimsey and others, 2013). 


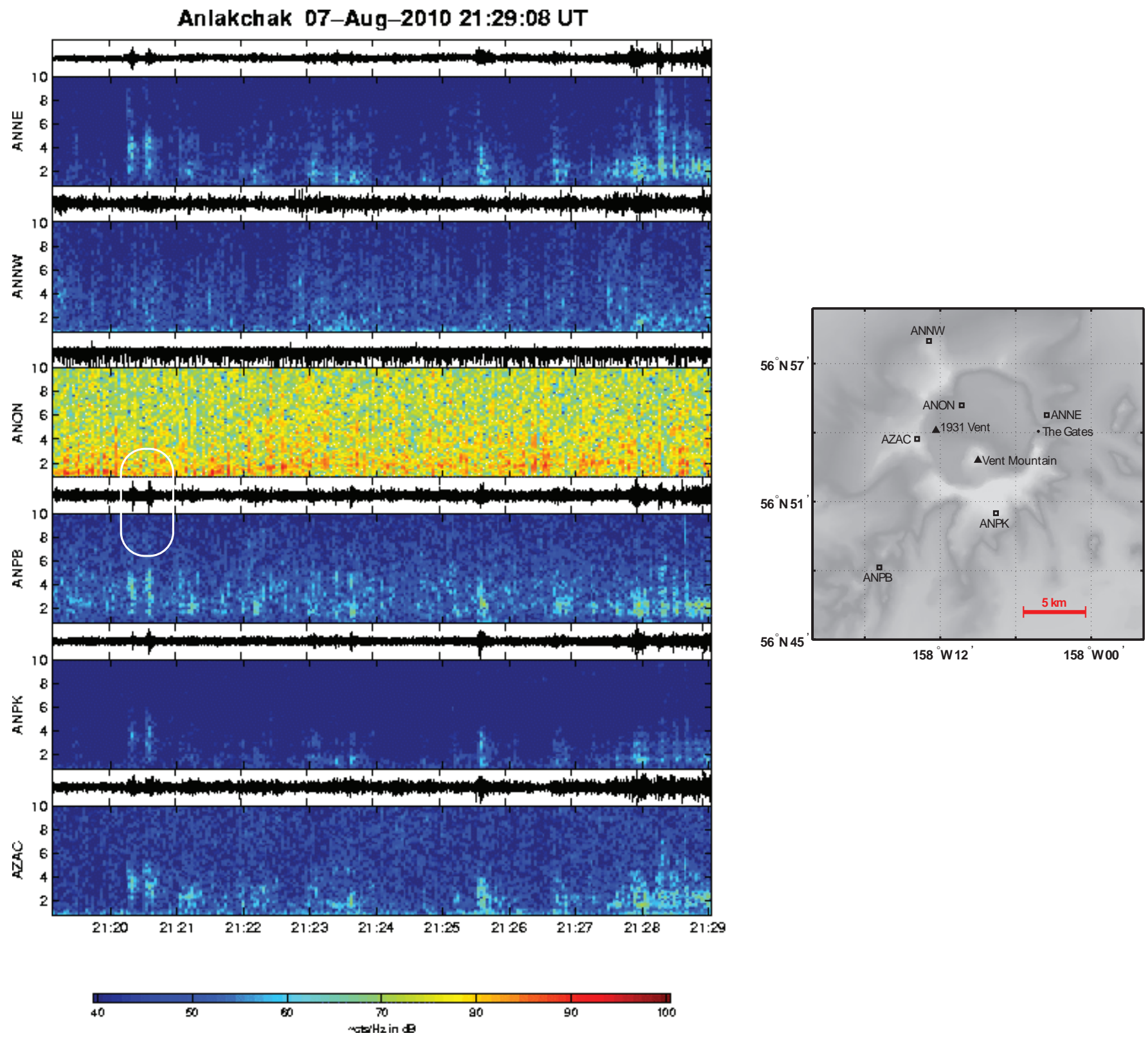

Figure 14. Spectrogram for Aniakchak seismic stations on August 7, 2010. A sequence of low-frequency events seen across the network (circled) was followed by about 7 minutes of possible tremor. One small low-frequency event was located by $S$. Stihler of USGS/AVO at a depth of about $23 \mathrm{~km}$ (14 mi) and epicenter about $6 \mathrm{~km}(4 \mathrm{mi})$ east-northeast of Vent Mountain. Inset shows seismic station map. 


\section{Mount Veniaminof Volcano}

CAVW\# 1102-07-

$56^{\circ} 12^{\prime} \mathrm{N} 159^{\circ} 24^{\prime} \mathrm{W}$

$2,507 \mathrm{~m}(8,225 \mathrm{ft})$

Alaska Peninsula

MINOR STEAMING AND OCCASIONAL SEISMICITY

Low-level seismicity with periodic small swarms and periods of tremor occurred throughout the year at Veniaminof. Most stations in the Veniaminof seismic network were inoperative from November 17, 2009, until July 2012 (Dixon and others, 2011); AVO removed the volcano from its 'monitored' list until August 12, 2010, following summer maintenance and repair.

White plumes of water vapor were frequently visible when the web camera in Perryville was operating (through April 1, 2010). AVO satellite analysis of AVHRR imagery showed a small steam plume during a stretch of clear weather in March. Possible thermal anomalies were associated with the summit during the same period, likely due to solar heating of the dark intracaldera cone surrounded by caldera glacier ice.

Veniaminof, an ice-clad, approximately $350-\mathrm{km}^{3}\left(84-\mathrm{mi}^{3}\right)$ andesite and dacite stratovolcano, is one of the largest and most active volcanoes of the Aleutian Arc (Miller and others,
1998; Bacon and others, 2007). Located 775 km (482 mi) southwest of Anchorage and $35 \mathrm{~km}$ (22 mi) north of Perryville (fig. 1), the summit hosts an ice-filled, 10-km diameter (6.2-mi) caldera. Two Holocene caldera-forming eruptions are recorded in extensive pyroclastic-flow deposits around the volcano (Miller and Smith, 1987). Low-level, largely phreatic ash explosions from the approximately 350-m-high (1,150-ft) intracaldera cone have occurred intermittently since 2002. The last significant magmatic eruption occurred in 1993-95 (Neal and others, 1995, 1996; McGimsey and Neal, 1996). This eruption was characterized by intermittent, low-level emissions of steam and ash, and production of a small lava flow that melted a pit in the caldera-ice field. During the more significant historical eruptions, ash plumes reached about 6,000 m (20,000 ft) ASL and produced ash fallout within about $40 \mathrm{~km}$ (25 mi) of the volcano. 


\section{Westdahl Volcano}

CAVW\# 1101-34-

$54^{\circ} 31^{\prime} \mathrm{N} 164^{\circ} 39^{\prime} \mathrm{W}$

$1,560 \mathrm{~m}(5,118 \mathrm{ft})$

Aleutian Islands

\section{INCREASED SEISMICITY}

In late July, AVO seismologists noted a marked increase in lower crustal seismicity at Westdahl (fig. 15). Most of the seismicity was long period in character however some volcano-tectonic events also were recorded.

Deep ( $>10 \mathrm{~km}$ or $>6.2 \mathrm{mi}$ ), low frequency events located with the Westdahl seismograph network tend to cluster in an area northwest of the volcano's summit. Past analysis of InSAR results for Westdahl by Lu and others (2003) suggests a shallow magma reservoir beneath the volcano. Continued inflation of the volcano is consistent with ongoing accumulation of melt at shallow levels. Such ascent of magma from depth may explain the 2010 seismicity at Westdahl.
Westdahl Volcano is a broad, gently sloping, ice-capped volcano on the western end of Unimak Island. It is inferred that the summit ice cap fills an older caldera structure. Faris and Westdahl Peaks are the youngest of the post-caldera vents within the caldera. Pogromni is a satellite vent that likely predates caldera formation (Calvert and others, 2005). Most known historical eruptions, including the 1991 event, have included an explosive phase involving the interaction of lava and ice followed by a lahar, production of a blocky lava flow, and construction of a cinder and spatter cone (Miller and others, 1998; Dean and others, 2002). The last notable unrest at Westdahl was a brief seismic swarm in January 2004 (Neal and others, 2005). 


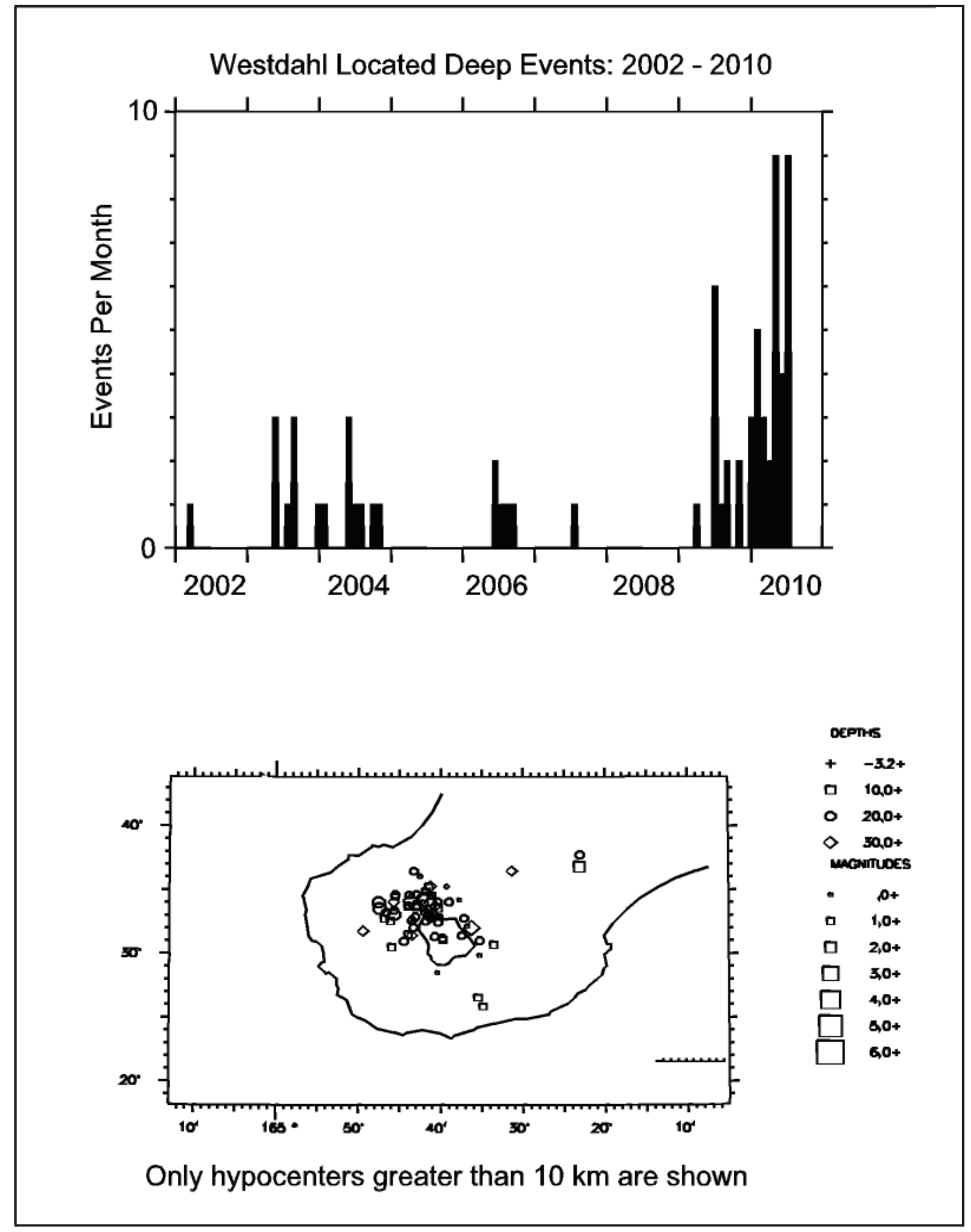

Figure 15. Plots of located events per month at Westdahl Volcano from 2002 through 2010. Note the clear increase in seismicity in late 2009 into 2010. The bottom panel shows epicenters of seismicity located northwest of the summit of the ice-clad volcano; depths of the events ranged from 10 to $50 \mathrm{~km}$ (6 to $31 \mathrm{mi}$ ). Figure courtesy J. Dixon, USGS/AVO. 


\section{Makushin Volcano}

CAVW\# 1101-31-

$53^{\circ} 53^{\prime} \mathrm{N} 166^{\circ} 56^{\prime} \mathrm{W}$

$1,800 \mathrm{~m}(5,906 \mathrm{ft})$

Aleutian Islands

ROBUST VAPOR PLUMES AND INCREASED SEISMICITY

Low level seismicity was recorded at Makushin Volcano throughout 2010. At about 7:00 p.m. Alaska Standard Time on February 17, a veteran pilot noted an unusual dark plume over the volcano during exceptionally clear conditions. Later, Guardian Flight paramedic Wayne Boots sent AVO images of strong fumarolic output at the Makushin summit from February 19 (fig. 16). AVO reviewed seismic data and saw no change of significance related to a possible plume. On February 24, a strong vapor plume was visible with satellite imagery but again, no change in seismicity was noted. On March 3, AVO satellite analysts reported slightly elevated temperatures in the vicinity of the summit craters; not an unusual observation for the fumarolically active summit of Makushin.

Seismicity increased slightly with a small swarm on April 7 and again in May. AVO did not elevate the Aviation
Color Code or Alert Level for Makushin for either of these slight departures from background.

Makushin Volcano is located on the eastern Aleutian island of Unalaska about $25 \mathrm{~km}$ (15 mi) west of the city of Unalaska/Dutch Harbor, ranked second in the U.S. in terms of dollar value of catch in 2010 (in the U.S. the U.S. port with the second highest dollar value of fishery landings in 2010 (National Marine Fisheries Service, 2014). The volcano is a broad, truncated stratovolcano with a 3-km (1.9-mi)wide summit caldera and a small intracaldera cinder cone. The summit is capped by a $40 \mathrm{~km}^{2}$ (about $15 \mathrm{mi}^{2}$ ) icefield. Makushin is credited with 18 historical eruptions, the latest of which occurred on January 30, 1995, and consisted of a small explosion that produced an ash plume that rose up to $10,000 \mathrm{ft}$ (3,000 m) ASL (McGimsey and Neal, 1996; McConnell and others, 1998; Beget and others, 2000).

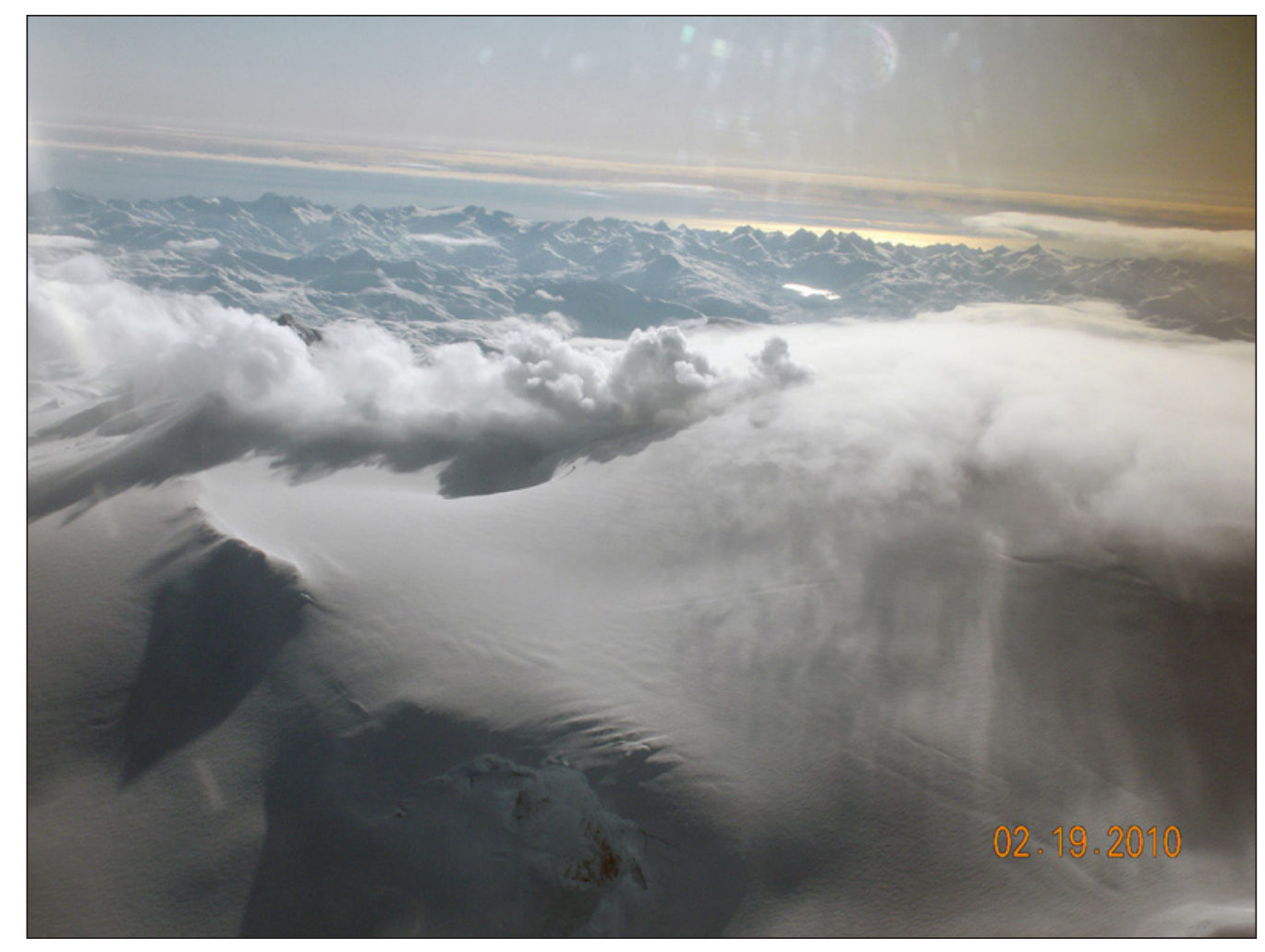

Figure 16. Oblique aerial view of the summit of Makushin Volcano. Photograph courtesy Wayne Boots, Guardian Flight, February 19, 2010. AVO database image at URL: http://www.avo.alaska.edu/ images/image.php? id=19493. 


\section{Cleveland Volcano}

CAVW\# 1101-24-

$52^{\circ} 49^{\prime} \mathrm{N} 169^{\circ} 57^{\prime} \mathrm{W}$

$1,730 \mathrm{~m}(5,676 \mathrm{ft})$

Chuginadak Island, east-central Aleutian Islands

\section{THERMAL ANOMALIES AND MINOR ASH PLUMES; NEARBY TECTONIC SWARM}

Ash clouds, thermal anomalies, ash fall and ballistics visible on island, flowage deposits reach the sea

2010 was another busy year for seismically unmonitored Cleveland volcano with intermittent small ash cloud production, visible vapor plumes, and periods of satellitedetected thermal anomalies in the summit region. A sudden and sustained increase in surface temperature in May prompted AVO to upgrade the Aviation Color Code and Volcano Alert Level from UNASSIGNED to YELLOW/ ADVISORY on May 25. After consistent thermal anomalies during the last week of May, AVO remote sensors detected a small ash plume on satellite imagery on May 30. The plume was traveling at an estimated altitude of 16,000 ft ASL and drifting south.

ASTER acquired a mostly clear view of Cleveland on June 1 (fig. 17). Recent dark flowage deposits are visible on the eastern flank and tephra-fall deposits blanket a swath to the southwestern coastline. The summit crater was hidden by a white vapor cloud.

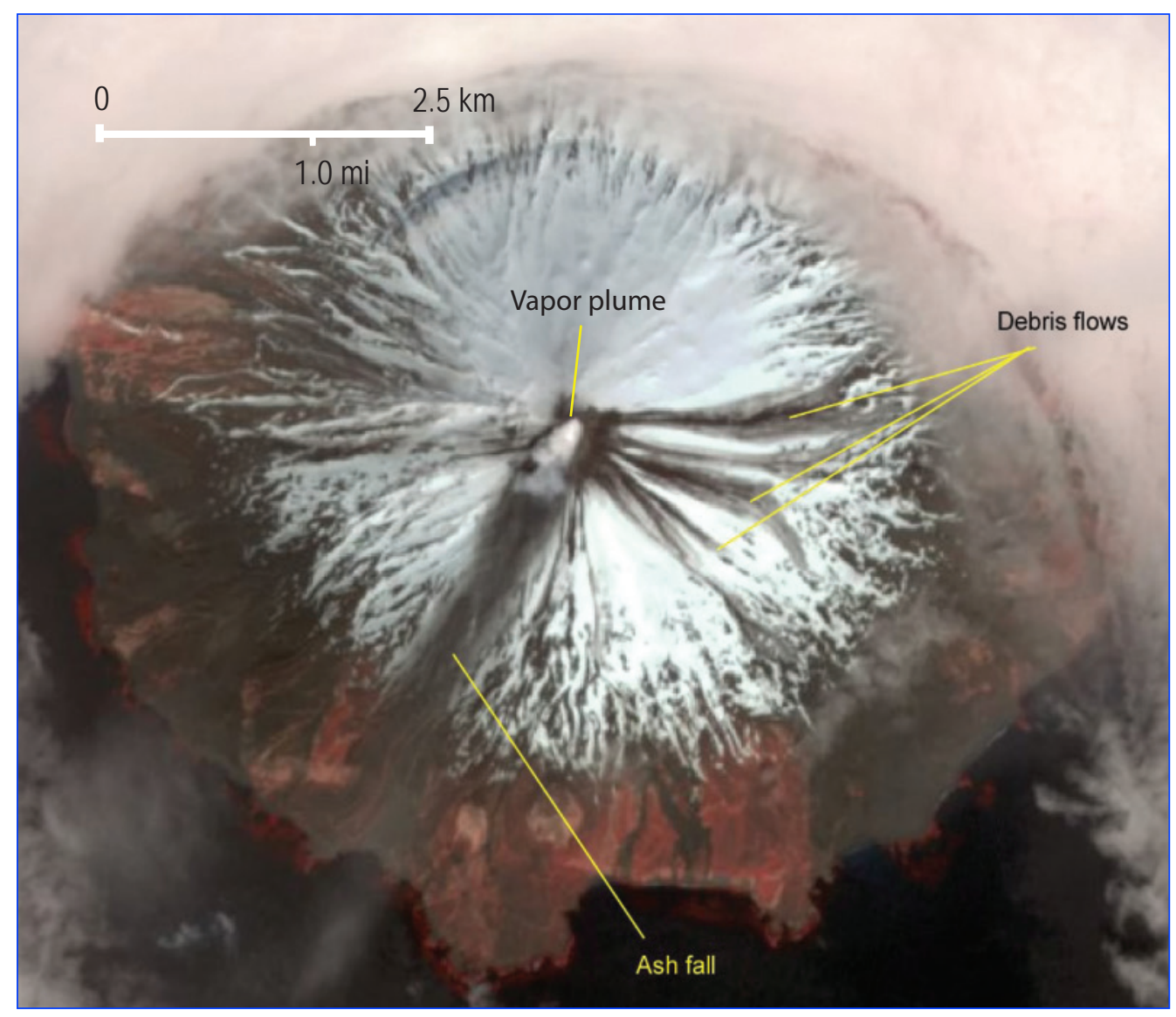

Figure 17. Cropped 15-m resolution ASTER visible/near infrared image showing recent debris flow and ash fall deposits on Cleveland Volcano. The image also shows light steaming from the summit crater. Image taken June 01, 2010, at 22:29:29. Courtesy of NASA/GSFC/METI/ERSDAC/JAROS, and U.S./Japan ASTER Science Team. 
Following the impulsive ash event on May 30, AVO ceased to detect consistently elevated surface temperatures and, without additional observations of activity, AVO returned the volcano to UNASSIGNED on June 11.

On 18 July, 2010, a magnitude 6.6 main-shock occurred $9 \mathrm{~km}$ (5.6 mi) northeast of the summit of Mount Cleveland. AVO field personnel on Umnak Island reported that buildings shook and fuel barrels rolled back and forth several inches (M. Kauffman, UAFGI/AVO, written commun., 2010). The earthquake also was felt in Unalaska/Dutch Harbor, although residents described the shaking as "light" or "weak."

This event triggered a subsequent earthquake cluster of more than 1,800 aftershocks greater than magnitude 2.5 and about 110 magnitude 4.0 or greater events. According to analysis by AEIC, a M 4.0 foreshock had occurred on July 17 at 14:44 UTC. Earthquakes during this time period were restricted to an approximately $25-\mathrm{km}$-wide (15-mi) area extending from eastern Chuginadak Island to the edge of the Aleutian platform about $60 \mathrm{~km}$ (37 mi) southeast (fig. 18). Most of the earthquakes were shallower than $15 \mathrm{~km}(9 \mathrm{mi})$. The largest aftershock of magnitude 6.0 occurred on July 18.

AEIC analysis of fault plane solutions for the large events of this series determined that the larger earthquakes were located on north-northwest-trending normal faults. This was the largest event to occur in the region since the magnitude 6.5 earthquake on October 13, 2009. Similar sized earthquakes occurred in the same area on May 10, 2006, and December 26, 2007. AEIC located nearly 3,200 aftershocks through end of July, including about 60 aftershocks with magnitudes 4.0 or greater.

The earthquake had no clear impact on Cleveland volcano; however, elevated temperatures reappeared at the summit throughout July and August. Based on this, AVO upgraded the Aviation Color Code and Volcano Alert Level to YELLOW/ADVISORY on August 26. On August 26, 29, and 31, pilots from Alaska Airlines flying the Anchorage to Adak route reported no volcanic ash from Mount Cleveland. Thermal anomalies continued into September but did not intensify; on September 10, the Aviation Color Code and Volcano Alert Level were downgraded to UNASSIGNED.

On September 12, the Anchorage VAAC reported a possible weak ash signal in satellite data. If this was an eruption cloud, the plume rose only a few thousand feet above the volcano's summit

Figure 18. Focal mechanisms for earthquakes during the July 2010 sequence in the central Aleutian Islands. Figure courtesy Alaska Earthquake Information Center. and dissipated quickly. A one-time VAA was released but no SIGMET was issued. AVO upgraded the Aviation Color Code and Volcano Alert Level to YELLOW/ADVISORY. Observations from a pilot in the area of Mount Cleveland reported that no ash was visible, at least below 2,900 ft. Clear satellite views continued to show elevated surface temperatures in the summit crater but no ash plumes.

Clouds frequently prevented remote viewing of the volcano but during periods of clear conditions, thermal anomalies were noted intermittently through the end of the year. AVO maintained Cleveland at Aviation Color Code and Volcano Alert Level YELLOW/ADVISORY. There were no reports of ash or other activity except for an anomalous infrasound signal that was received on September 15 at 00:24 and 00:30 UTC (Steve McNutt, UAFGI/AVO, written commun., 2010) and may have represented a small explosion from the volcano.

The 2010 activity at Cleveland is considered a continuation of the intermittent explosive activity that has characterized the volcano since its last significant eruption in 2001 (Dean and others, 2004). Cleveland forms the western portion of Chuginadak Island, an uninhabited island in the east-central Aleutians about $73 \mathrm{~km}(45 \mathrm{mi})$ west of the community of Nikolski, and 1,500 km (940 mi) southwest of Anchorage. Historical eruptions have been characterized by short-lived ash explosions, lava fountaining, lava flows, and pyroclastic avalanches down the flanks. In February 2001, three explosive events produced ash clouds as high as $12 \mathrm{~km}$ $(39,000 \mathrm{ft}) \mathrm{ASL}$, a rubbly lava flow, and a hot avalanche that reached the sea (Dean and others, 2004). Cleveland is unmonitored by ground-based geophysical instrumentation. In 2011, AVO began development of an infrasound alarm technique to detect explosions at Cleveland (Fee and others, 2010; De Angelis and others, 2012.) 


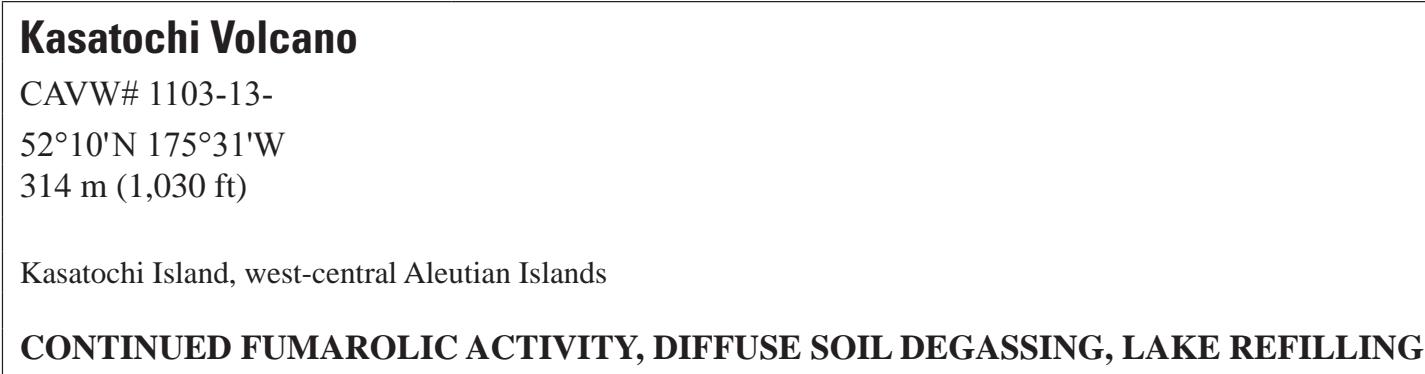

In the year following the dramatic explosive eruption of remote Kasatochi Volcano in 2008 (Scott and others, 2010; Waythomas and others, 2010), seismicity beneath the volcano continued, but the number of located events gradually waned (Dixon and others, 2011). At the surface, the summit crater again hosted a lake that drowned numerous fumaroles on the post-eruption crater floor and walls; debris on the lake attested to ongoing magmatic degassing (fig. 19). Wave action and rain-mobilization of material on the island dramatically altered the surface cover of pyroclastic debris, producing deep erosional gullies (ig. 20). In places, the coastline (which had been extended as much as several hundred meters by addition of material during the eruption) had retreated to near pre-eruption locations due to wave action (C. Waythomas, USGS/AVO, written commun., 2012).

AVO sent several field parties to the island as part of the ongoing multi-disciplinary studies of the eruption, its aftermath, and the recovery of the island ecosystem (Degange and others, 2010). For the first time, an attempt was made to measure sulfur dioxide using the FLYSPEC; measurements by CVO geologist A. Diefenbach were unsuccessful due to limited ultraviolet radiation under heavy Aleutian cloud cover.

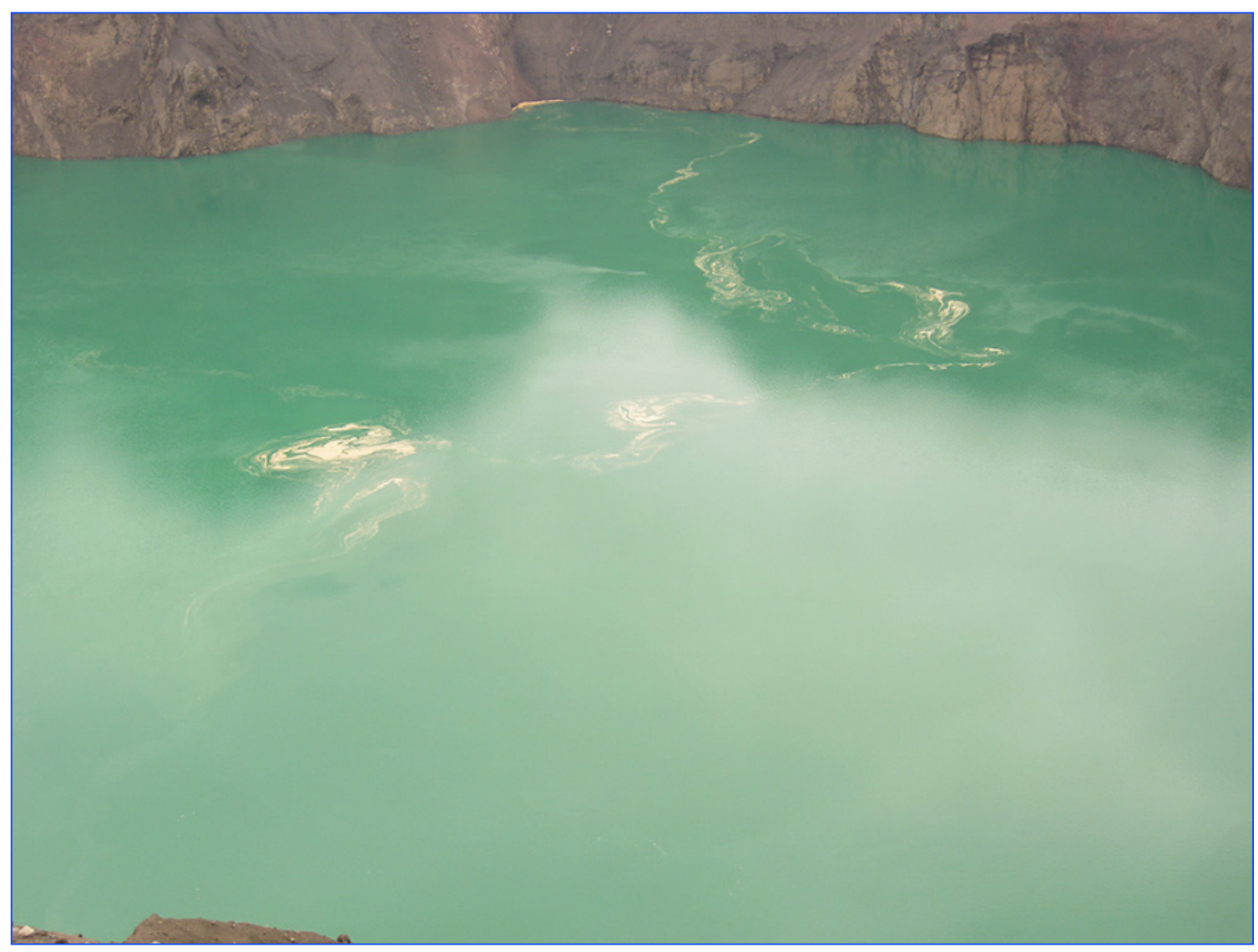

Figure 19. View from the crater rim of the lake surface within Kasatochi Volcano's summit crater. Floating patches of yellow-tan debris are likely sulfur precipitate from submerged fumaroles on the lake floor. Smaller, similar looking patches were visible on the pre-eruption lake surface in 2005 (Neal and others, 2007, figs. 44 and 45). Photograph by W. Scott, USGS/AVO, August 11, 2010. 
However, field crews did not detect any smell of sulfur during their time on the island. The last known report of sulfur smell from Adak was in December 2009 (Chris Nye, ADGGS/AVO written commun., 2010). A soil survey for carbon dioxide was successful, although limited in aerial coverage by weather and available time. Above background concentrations of $\mathrm{CO}_{2}$ were detected at several sites (A. Diefenbach, USGS/Cascade Volcano Observatory, written commun., 2010) including the area where two fork-tailed storm-petrels were found dead in the summer of 2009, presumably asphyxiated (Jeff Williams, U.S. Fish and Wildlife, written commun., 2009; Scott and others, 2010).

Kasatochi Volcano is in the central Aleutians, about $840 \mathrm{~km}$ (about $522 \mathrm{mi}$ ) west-southwest of the tip of the Alaska Peninsula. In 2008, Kasatochi erupted violently through its summit lake sending and ash and gas cloud to $15 \mathrm{~km}$ (50,000 ft) ASL and completely covering the island and portions of the near-shore with pyroclastic fall, surge, and flow deposits (Scott and others, 2010). Prior to the 2008 eruption, the island measured about $2.6 \times 3 \mathrm{~km}$ (about $1.6 \times 1.9 \mathrm{mi}$ ) and had a central, lake-filled, vertical-walled summit crater about $800 \mathrm{~m}$ (about 2,600 ft) in diameter. The surface of the lake was estimated to be about $50 \mathrm{ft}$ (about $15 \mathrm{~m}$ ) ASL in 2005 using the helicopter's radar altimeter (McGimsey and others, 2007). The pre-2008 record of historical eruptive activity at Kasatochi is poorly known. The island was reported as “emerging” in 1760 by Grewingk (1850, and as cited in Miller and others, 1998) and as "smoking" in 1827 and 1828. USFWS observers reported 'increased steaming' at Kasatochi volcano following a M 6.0 earthquake in June 1996 (Neal and McGimsey, 1997); however, the exact source of steaming is not recorded. USFWS scientists on the island reported bubbling through the crater lake from 2005 to 2007 (McGimsey and others, 2007; Neal and others, 2009b; McGimsey and others, 2011).

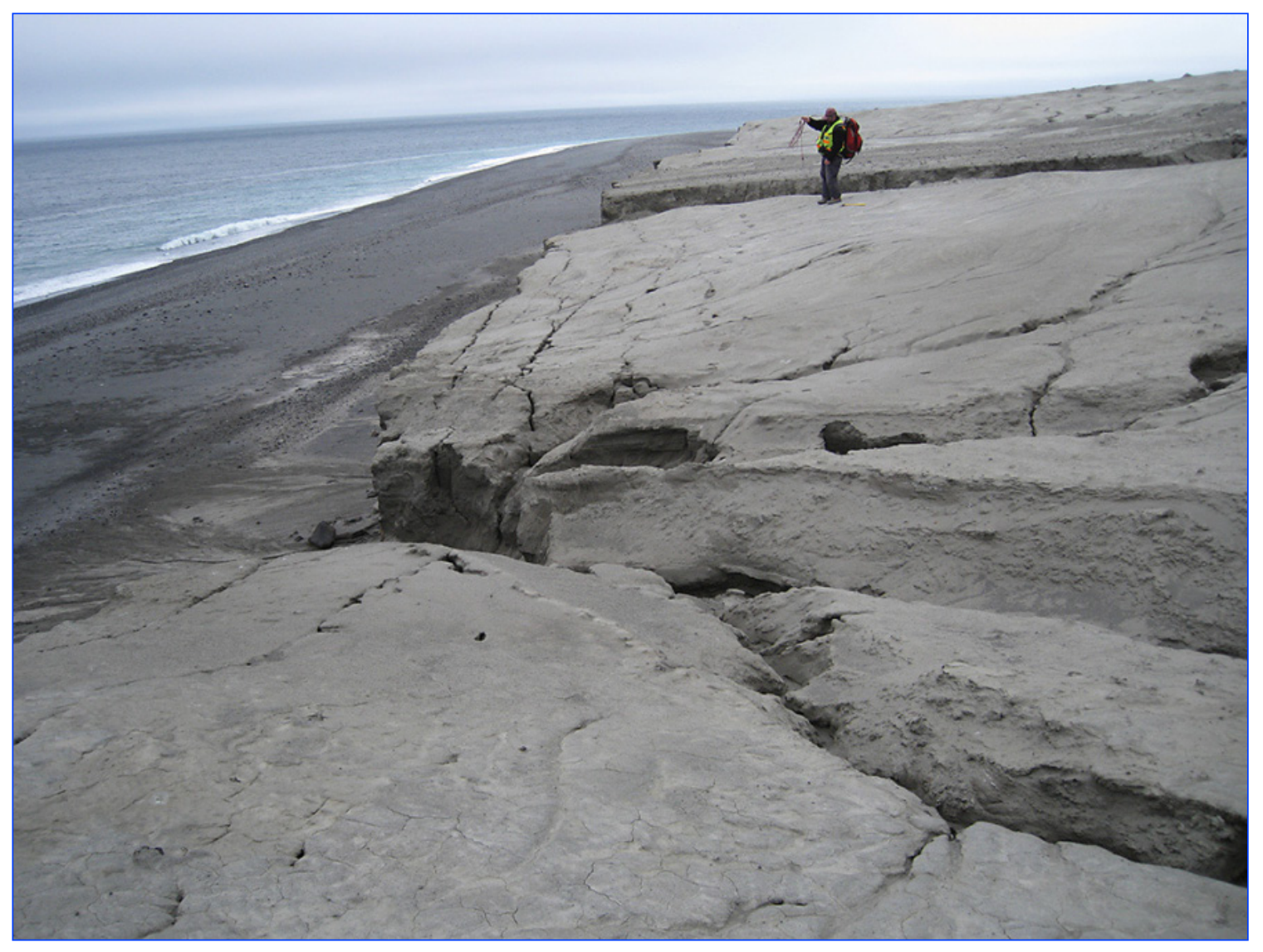

Figure 20. Coastline of Kasatochi Volcano. AVO geologist is measuring the height of the terrace above the beach. Photograph by W. Scott, USGS/AVO, June 18, 2010. AVO database image at URL: http://www.avo.alaska. edu/images/image.php? id=28432. 


\section{Volcanic Activity, Kamchatka Peninsula, and the Northern Kurile Islands, Russia}

More than 60 potentially active volcanoes on Russia's Kamchatka Peninsula and Kurile Islands pose a serious threat to aircraft in the North Pacific (Neal and others, 2009b). The primary responsibility for monitoring and alerting the aviation community to activity in Russia lies with the Kamchatka Volcanic Eruptions Response Team (KVERT) for Kamchatka and the northern Kuriles, and the Sakhalin Volcanic Eruption Response Team (SVERT) for the remaining Kuriles (see section, "Volcanic Activity, Central and Southern Kurile Islands").

KVERT is a cooperative program consisting of scientists from the Institute of Volcanology and Seismology (IVS), the Kamchatka Branch of Geophysical Services (KBGS), and AVO. KBGS monitors 11 of the most frequently active volcanoes in Kamchatka with one or more seismometers and satellite imagery (table 5; fig. 21). The IVS component of KVERT also analyzes AVHRR, MODIS, and MTSAT satellite imagery of Russian Far East volcanoes daily. KVERT also uses imagery from web cameras to track activity at Sheveluch, Klyuchevskoy, Bezymianny, Koryaksky, and Avachinsky volcanoes. KVERT receives occasional reports of volcanic activity from scientific observers in the communities of Severo-Kurilsk on Paramushir Island in the north Kuriles and from Klyuchi, and Kozyrevsk

Figure 21. Kamchatka Peninsula and the northern Kurile Islands of Alaid and Paramushir Volcanoes discussed in this report are in bold red type. on the Kamchatka Peninsula (for location see fig. 21). KVERT also receives reports from scientific field parties working in the vicinity of Karymsky Volcano, and pilot reports of volcanic activity are relayed to KVERT from the local Civil Aviation Meteorological Center at Yelizovo Airport located just west of Petropavlovsk (fig. 21). AVO conducts routine satellite monitoring of portions of the Russian volcanic arc and shares twice-daily satellite monitoring reports with KVERT staff by email. By formal agreement, AVO also assists with dissemination of hazard information for eruptions from the Kuriles and Kamchatka.

A total of six volcanoes in Kamchatka were active in 2010 (table 6). Summaries of this activity and related Aviation Color Code changes for Russian volcanoes are listed in table 7.

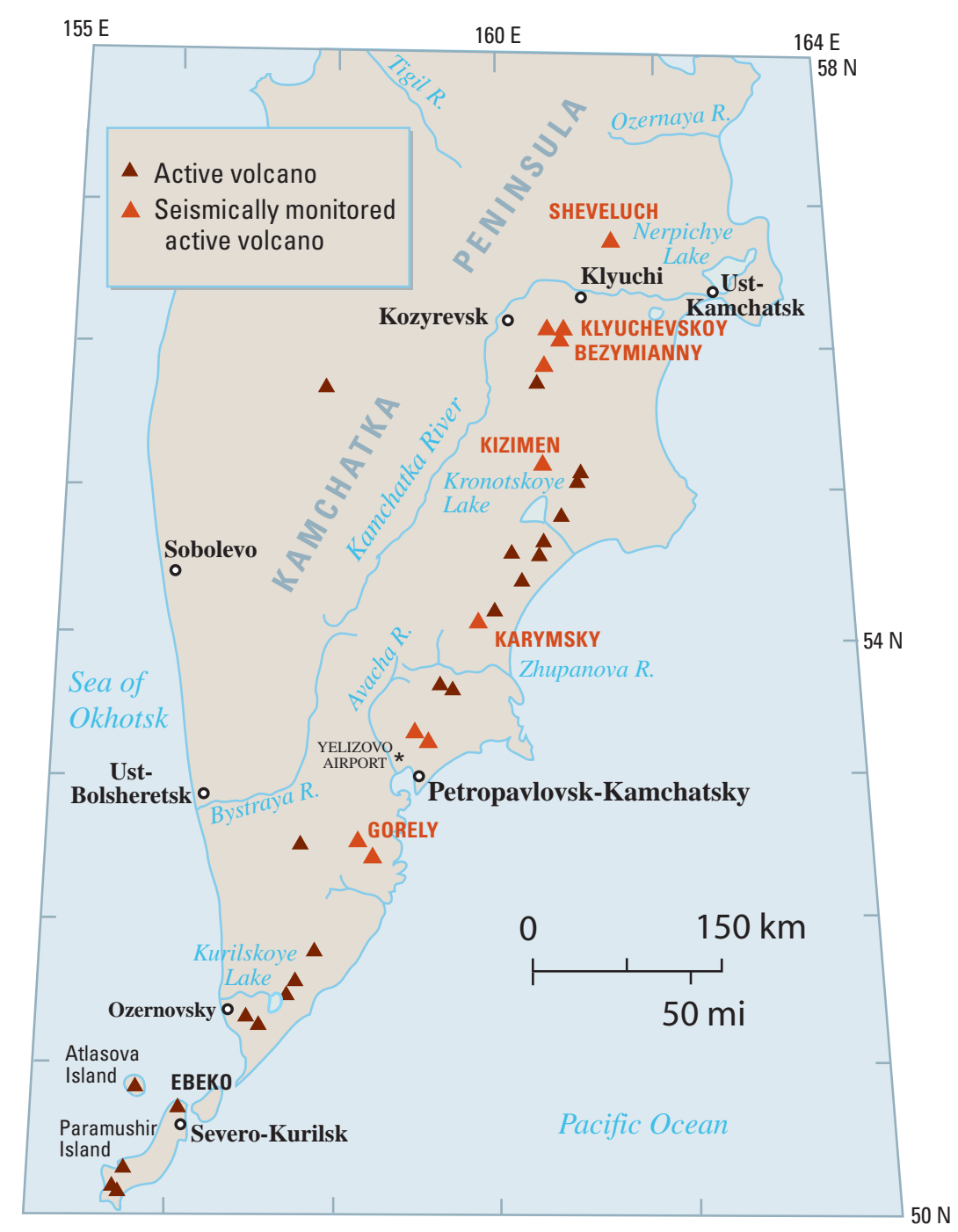


Table 5. Seismically monitored volcanoes of Kamchatka as of December 2010.

[Compiled by S. Senyukov, Kamchatka Branch of Geophysical Surveys (KBGS. Prior to 1979, other Russian scientific institutes maintained programs of volcano monitoring in Kamchatka (a partial listing includes: 1961-1971, Pacific Seismological Department of Institute of Earth Physics; 1972-1978 - Institute of Volcanology). PK - Petropavlovsk, Kamchatska]

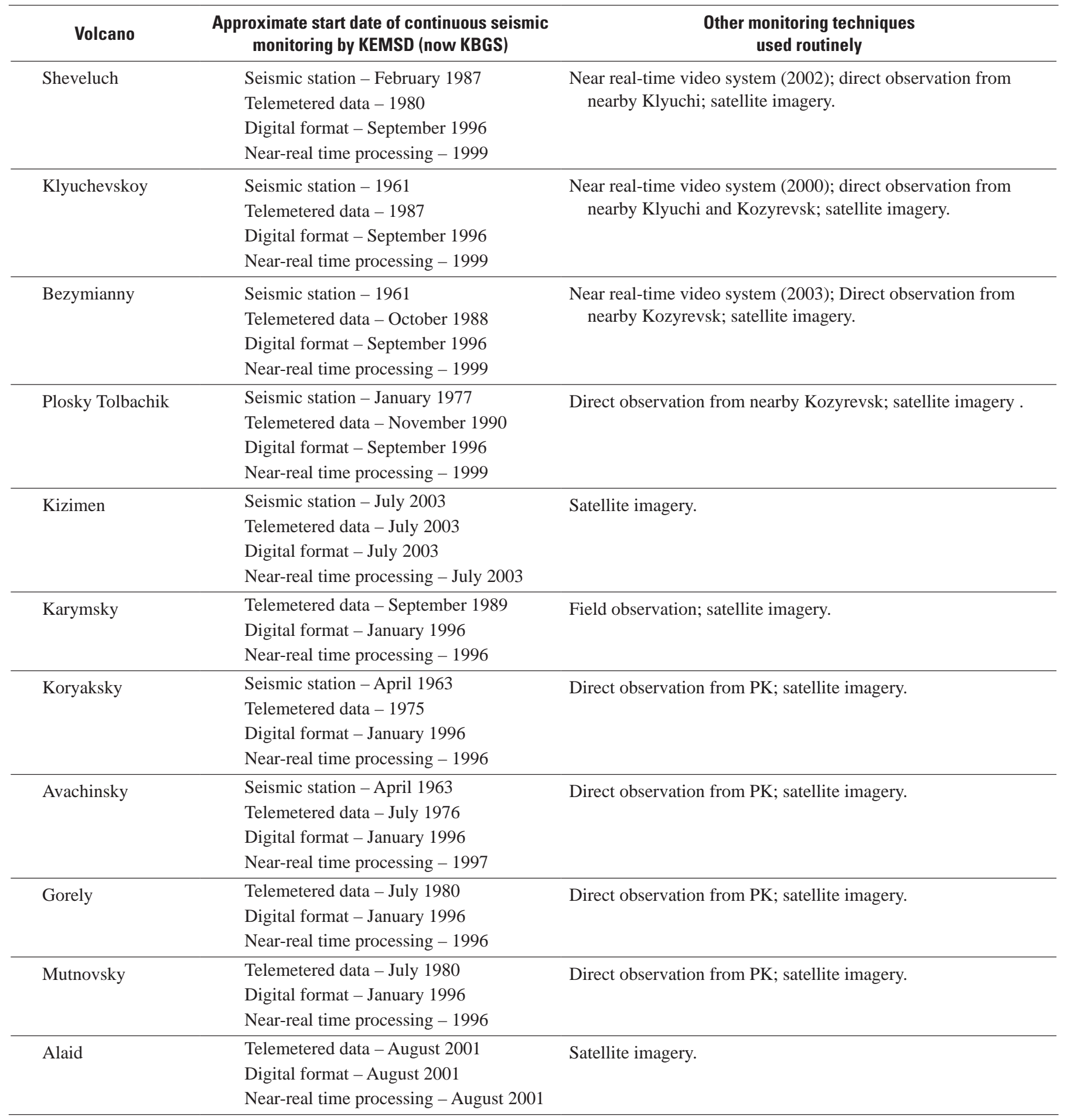


Table 6. Summary of volcanic activity on Kamchatka Peninsula and in the Kurile Islands, Russia, 2010.

[Location of volcanoes shown in figures 21 and $\underline{38}$ ]

\begin{tabular}{lll}
\hline \multicolumn{1}{c}{ Volcano } & \multicolumn{1}{c}{ Date of activity } & \multicolumn{1}{c}{ Type of activity } \\
\hline $\begin{array}{l}\text { Sheveluch } \\
\text { Klyuchevskoy }\end{array}$ & $\begin{array}{l}\text { Intermittently active throughout } 2010 \\
\text { Intermittently active throughout much of } \\
\text { the year } \\
\text { Intermittently throughout the year }\end{array}$ & $\begin{array}{c}\text { Lava dome growth, short-lived, explosive episodes, pyroclastic } \\
\text { avalanches, ash clouds, local ash fall. } \\
\text { Strombolian lava fountaining, Vulcanian explosions, lava flows, lahars, } \\
\text { phreatic explosions. }\end{array}$ \\
$\begin{array}{l}\text { Kizimen } \\
\text { Karymsky }\end{array}$ & $\begin{array}{c}\text { Short-lived explosive event in August, continued lava extrusion. } \\
\text { Intermittently throughout the year }\end{array}$ & $\begin{array}{c}\text { Periods of increased seismicity continuation of low-level Vulcanian and } \\
\text { Strombolian explosions, ash fall. }\end{array}$ \\
Gorely & June through year's end & Increased seismicity, thermal output, degassing. \\
Ekarma & June & Phreatic explosion, lahar, tephra fall.
\end{tabular}

Table 7. Aviation Color Code changes for Kamchatkan volcanoes in 2010.

[For a complete record of Russian Aviation Color Code changes and supporting information, please see the archives of KVERT messages at http://www.kscnet.ru/ivs/kvert/van/index.php]

\begin{tabular}{|l|l|}
\hline Aviation Color Code & \multicolumn{1}{c|}{ SHEVELUCH } \\
\hline ORANGE & January 1-October 27 \\
\hline RED & October 27-October 30 \\
\hline ORANGE & October 30-December 31 \\
\hline \multicolumn{2}{|c|}{ KLYUCHEVSKOY } \\
\hline ORANGE & January 1-October 22 \\
\hline RED & October 22-October 23 \\
\hline ORANGE & October 23-October 24 \\
\hline RED & October 24-October 30 \\
\hline ORANGE & October 30-November 9 \\
\hline YELLOW & November 9-November 25 \\
\hline ORANGE & November 25-December 17 \\
\hline YELLOW & December 17-December 31 \\
\hline \multicolumn{2}{|c|}{ BEZYMIANNY } \\
\hline YELLOW & January 1-February 7 \\
\hline ORANGE & February 7-February 11 \\
\hline YELLOW & February 11-May 24 \\
\hline ORANGE & May 24-May 31 \\
\hline RED & May 31 (2045 UTC)-June 1 (2230 UTC) \\
\hline ORANGE & June 1-June 3 \\
\hline YELLOW & June 3-December 31 \\
\hline
\end{tabular}

\begin{tabular}{|c|c|}
\hline Aviation Color Code & Date of change \\
\hline \multicolumn{2}{|r|}{ KIZIMEN } \\
\hline GREEN & January 1-November 25 \\
\hline YELLOW & November 25-December 10 \\
\hline ORANGE & December 10-December 12 \\
\hline RED & December 12-December 13 \\
\hline ORANGE & December 13-December 27 \\
\hline RED & December 27-December 29 \\
\hline ORANGE & December 29-December 31 \\
\hline RED & December 31 \\
\hline \multicolumn{2}{|r|}{ KARYMSKY } \\
\hline ORANGE & January 1-February 25 \\
\hline YELLOW & February 25-March 29 \\
\hline ORANGE & March 29-December 31 \\
\hline \multicolumn{2}{|r|}{ GORELY } \\
\hline GREEN & January 1-June 24 \\
\hline YELLOW & June 24-December 31 \\
\hline \multicolumn{2}{|r|}{ ALAID } \\
\hline GREEN & January 1-May 24 \\
\hline YELLOW & May 24-May 27 \\
\hline GREEN & May 27-December 31 \\
\hline \multicolumn{2}{|r|}{ EBEKO } \\
\hline GREEN & January 1-July 2 \\
\hline YELLOW & July 2-July 22 \\
\hline GREEN & July 22-December 31 \\
\hline
\end{tabular}




\section{Sheveluch Volcano}

CAVW\# 1000-27-

$56^{\circ} 38^{\prime} \mathrm{N} 161^{\circ} 21^{\prime} \mathrm{E}$

$3,283 \mathrm{~m}(10,771 \mathrm{ft})$

$2,500 \mathrm{~m}(8,200 \mathrm{ft})$

approximate elevation of the active lava dome

Kamchatka Peninsula

LAVA DOME GROWTH CONTINUES

Occasional ash plumes, pyroclastic avalanches

The ongoing eruption of Sheveluch continued throughout 2010. Nearly continuous extrusion of lava in the active dome complex produced a persistent thermal anomaly visible in satellite imagery. Periodically, ash explosions (fig. 22) as high as $12 \mathrm{~km}(40,000 \mathrm{ft})$ ASL accompanied by hot block and ash avalanches and ash fall in neighboring Klyuchi characterized the activity. The volcano was assigned Aviation Color Code ORANGE by KVERT from January 1 through October 27.

Beginning in late August, seismicity began increasing gradually, and, on October 27 at 14:00 UTC, a significant explosion destroyed a large part of the lava dome. Pyroclastic flow deposits covered an extensive area on the southeastern slope of the volcano (Girina and others, 2010). Due to bad weather conditions, visual observations were impossible, but a part of the large ash plume heading east from the volcano was seen from Klyuchi through breaks in the clouds. At 18:00 UTC on October 27, ash fall began in Ust-Kamchatsk (location on fig. 21). The road between Ust-Kamchatsky and Klyuchi was closed due to poor visibility, which locally decreased to $10 \mathrm{~m}$ (33 ft) as ash was falling. By 21:00 UTC, ash and snow had fallen as thick as $5 \mathrm{~cm}$ (2 in.) in UstKamchatsk. The Aviation Color Code was changed to RED on October 27 at 21:55 UTC.
About 03:00 UTC on October 28, the ash cloud extended over the Pacific Ocean (fig. 23). Ash from the October 27 event was well imaged by AVHRR satellite, and by October 28-29, the ash plume stretched 2,500 km (1,500 mi) downwind. As seen in ASTER satellite images, pyroclastic flow deposits on the southeastern flank of the volcano covered about $20 \mathrm{~km}^{2}\left(7.7 \mathrm{mi}^{2}\right)$. The October 27 Sheveluch event also was detected by the World Wide Lightning Location Network, developed by Washington State University, USA (Ewert and others, 2010).

The Aviation Color Code was changed to ORANGE on October 30 following cessation of explosive activity and ash production. Growth of the lava dome continued through the end of the year.

Sheveluch Volcano is one of the largest and most active of Kamchatkan volcanoes with at least 60 large eruptions during the Holocene (Bogoyavlenskaya and others, 1985; Ponomareva and others, 1998). Historical eruptive activity has been characterized by lava-dome growth and explosive collapse, often accompanied by large pyroclastic flows. A catastrophic flank collapse event in 1964 formed the modern amphitheater within which the active lava dome is now growing (Melekestsev and others, 1991; Zharinov and others, 1995; Ramsey and others, 2012). The current phase of lavadome growth and explosive activity began in late September 1980 and has continued intermittently into 2012. 


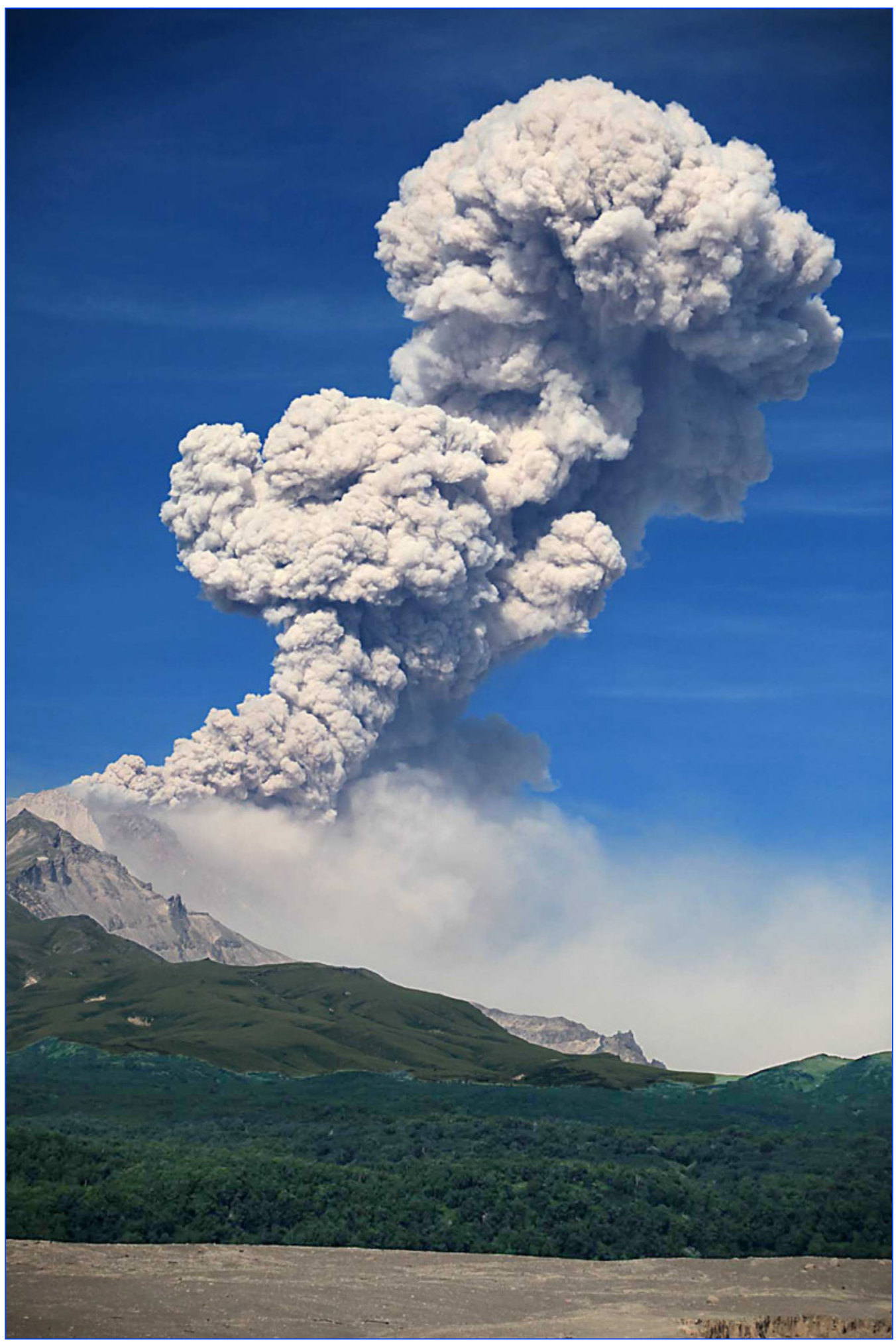

Figure 22. Ash plume from Sheveluch activity. Photograph by Yu. Demyanchuk, IVS, July 21, 2010. 


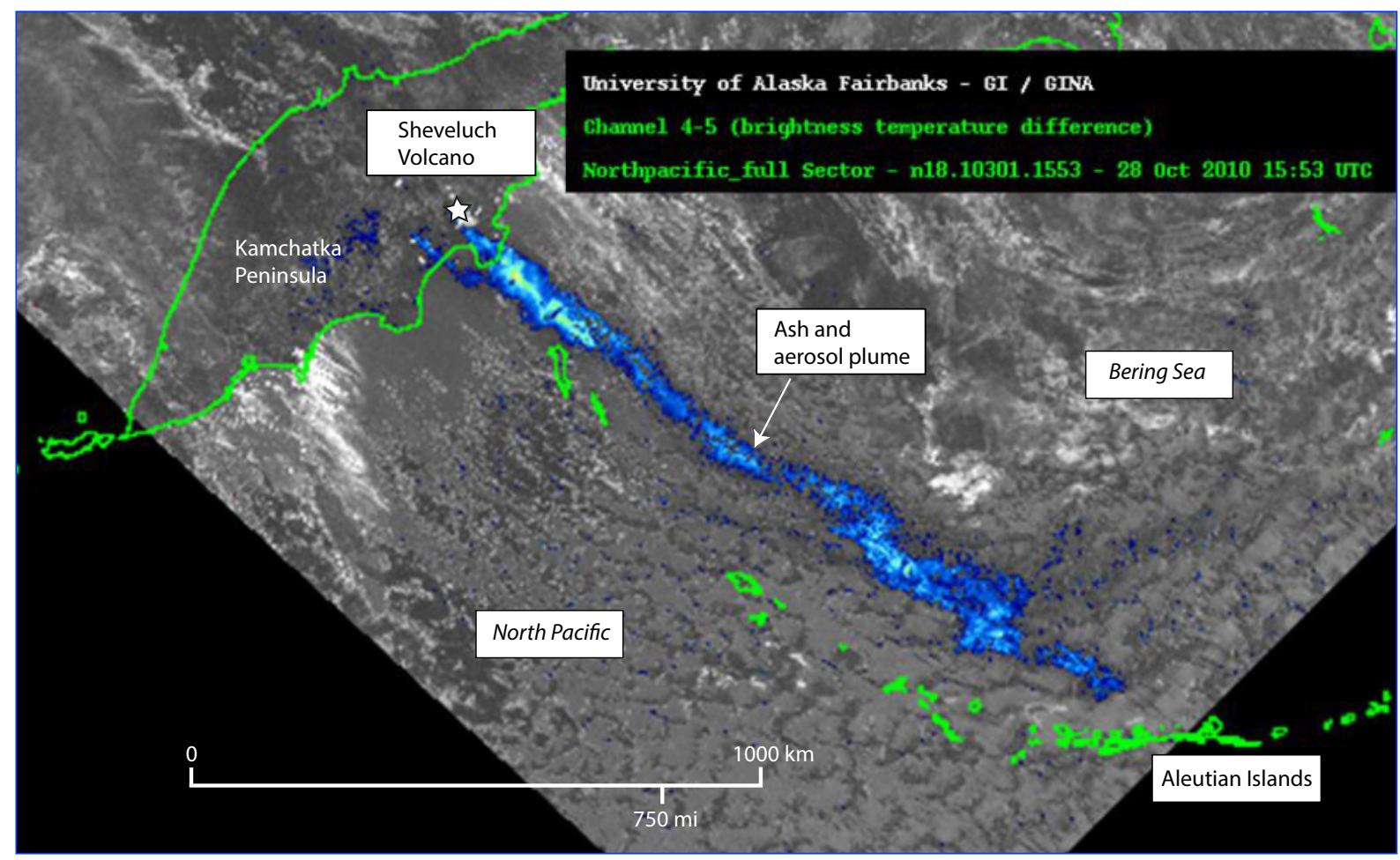

Figure 23. AVHRR satellite image showing Sheveluch ash cloud drifting downwind over the Bering Sea toward the central Aleutian Islands on October 28, 2010. Image courtesy UAFGI/AVO. 


\title{
Klyuchevskoy Volcano
}

\author{
CAVW\# 1000-26-
}

$56^{\circ} 03^{\prime} \mathrm{N} 160^{\circ} 38^{\prime} \mathrm{E}$

$4,750 \mathrm{~m}(15,585 \mathrm{ft})$

Kamchatka Peninsula, Russia

\section{INCREASED EXPLOSIVITY AND LAVA FLOW PRODUCTION}

Strombolian and Vulcanian activity, ash plumes, ash falls, lava flows, phreatic explosions as lava flow interacts with glacial ice

For most of 2010, the long-running explosive-effusive eruption at Klyuchevskoy volcano continued (Girina and others, 2010). KVERT assigned the volcano Aviation Color Code ORANGE from January 1 through October 22. Activity was characterized by nearly continuous Strombolian or Vulcanian activity from the summit crater. Tephra production was of variable intensity. Occasionally, eruption columns rose as high as $8 \mathrm{~km}(26,000 \mathrm{ft})$ ASL. Attendant plumes of volcanic gas were visible in satellite downwind as far as $575 \mathrm{~km}$ (360 mi; fig. 24). Seismicity from January to early November remained moderate or strong and volcanic tremor was nearly continuous. In late August and October 2010, there were periods of increased activity. Strong thermal anomalies over the volcano's summit and flanks were common during periods of Strombolian and lava flow production.

Continuous lava flow production and advance down the southeastern slope of the volcano (into the Apahonchich chute) had begun the previous year on November 13, 2009 (Girina and others, 2010.) In early January 2010, a new lava flow began to advance down the northwestern flank (into the Krestovsky chute); by January 15 , the lava flow was more than $1 \mathrm{~km}(3,300 \mathrm{ft})$ long as measured on satellite images. Between January 15 and February 8, occasional phreatic explosions occurred at the front of this lava flow where interaction with glacier ice was concentrated. Bursts of ash and vapor from these explosions reached $8 \mathrm{~km}$ (26,000 ft) ASL on January 15-22 and weak ash fall was noted in Klyuchi on January 22.

A second lava flow was detected on the northwestern slope on February 7. By March 4, two additional lava flows had formed on the southern flank. On April 9, a steaming new fissure extended from the crater rim down the southern flank (figs. 25-26). Subsequently, this fissure became the source for yet another lava flow lobe.

Throughout the spring and into the fall, a plume of gas and variable amounts of ash was emitted nearly continuously from the summit crater. At least two ash fall events occurred in Klyuchi. Lava-flow activity continued on the southwestern and southeastern flanks. A growing cinder cone within the summit crater reached well above the crater rim. Stombolian activity from the summit crater was especially dramatic at night (fig. 27). Phreatic explosions were observed at the lava and snow/ice interface producing plumes as high as $8 \mathrm{~km}$ $(26,000 \mathrm{ft})$ ASL.

Following an increase in the amplitude of volcanic tremor in October, the Aviation Color Code was upgraded briefly to RED from October 22 to 23 and again from October 24 to 30 . KVERT described the seismicity of the volcano as very unstable and was concerned about a larger explosive event or increasingly intense ash output; during this time, eruption plumes rose up to $9 \mathrm{~km}(30,000 \mathrm{ft})$ ASL and were detected as far as 2,300 $\mathrm{km}(1,400 \mathrm{mi})$ downwind over the Aleutian Islands (fig. 28). Activity decreased on October 30.

November saw continuing ash explosions and another ash fall of $4 \mathrm{~cm}$ (1.6 in.) thickness atop snow in Klyuchi on November 4. Following this, seismicity at Klyuchevskoy decreased markedly and continuous explosive activity ceased. The Aviation Color Code was changed to YELLOW on November 9. A resumption of ash explosions in late November prompted a return to ORANGE on November 25. Ash rose as high as $6.5 \mathrm{~km}$ (21,000 ft) ASL on November 26 and 29 and additional ash falls were recorded in Kozyrevsk on November 27 and in Klyuchi on November 28.

In December, activity at the volcano gradually decreased and KVERT downgraded the volcano to YELLOW on December 17 where it remained until year's end. Satellitedetected thermal anomalies persisted but slowly weakened as activity waned.

Klyuchevskoy, the tallest active volcano in Eurasia, is frequently active with Strombolian to Vulcanian explosions and lava-flow production from the steep-walled summit crater or from flank vents (Khrenov and others, 1991). Explosive eruptions have been recorded in nearly every decade and at multiple times during most years since the early 1700s (Siebert and others, 2010). 


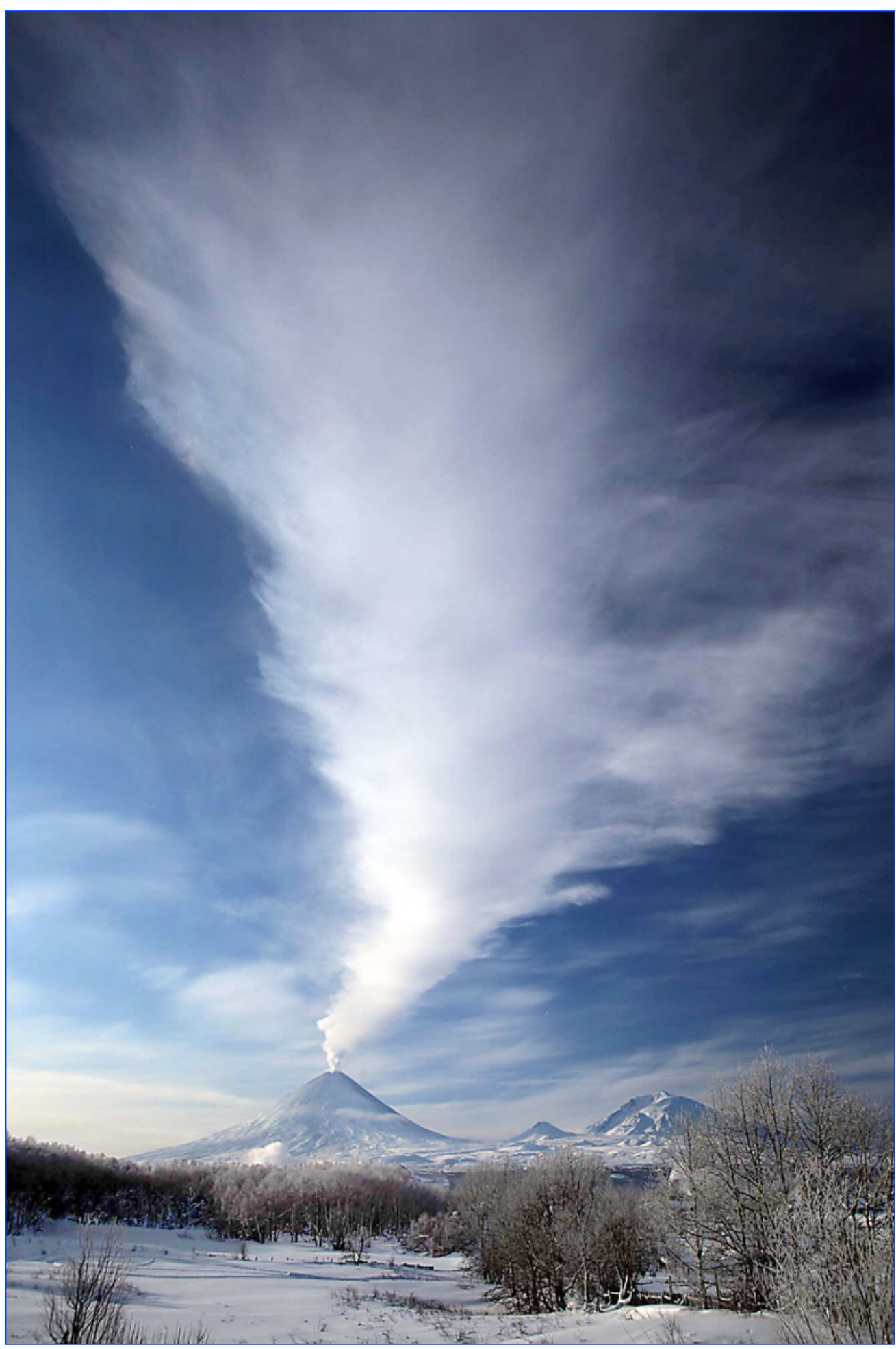

Figure 24. Gas-water vapor plume containing minor amounts of ash drifting downwind from Klyuchevskoy Volcano. Photograph by Yu. Demyanchuk, IVS, February 10, 2010. 


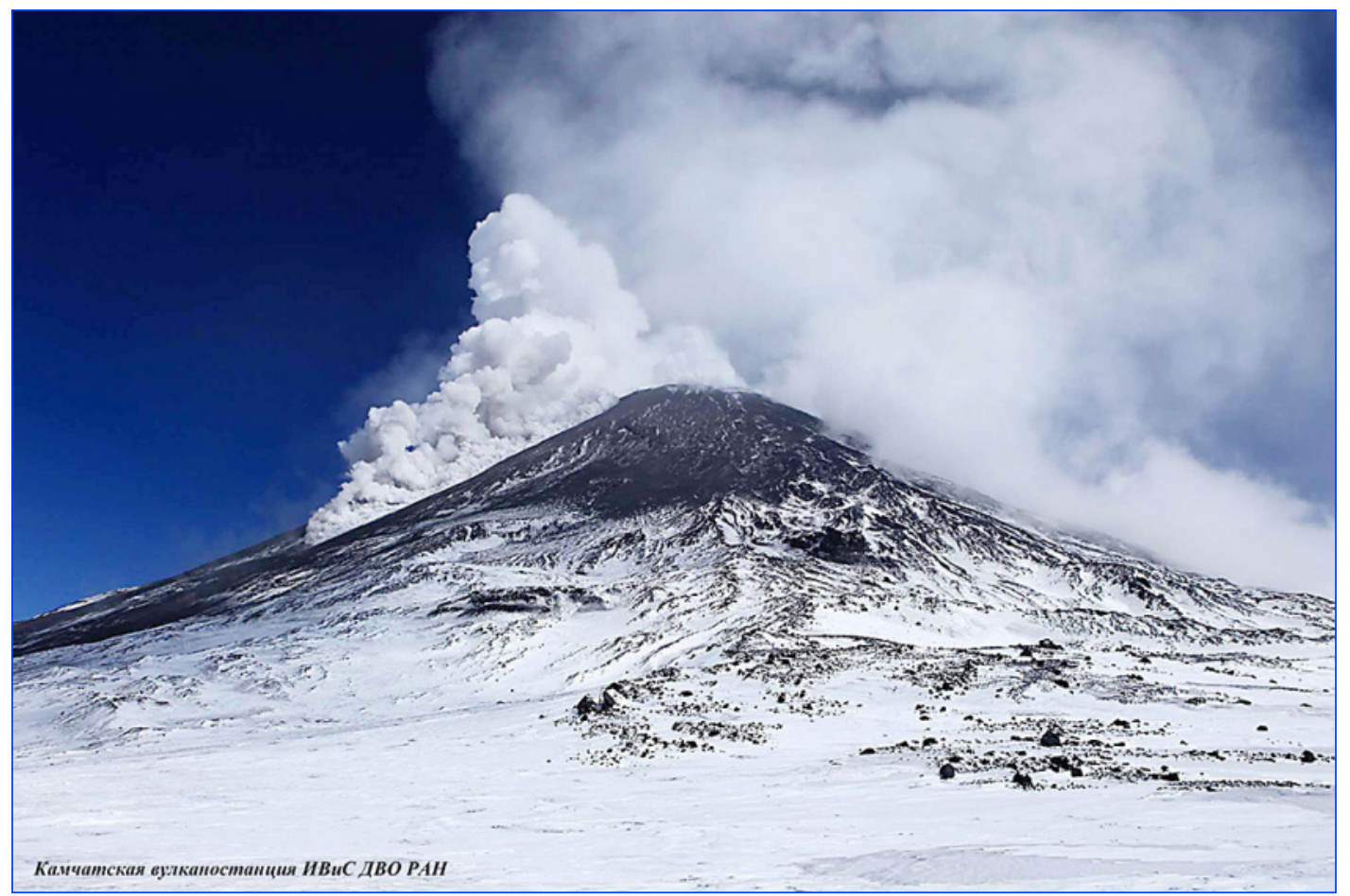

Figure 25. Phreatic activity on the southwestern flank of Klyuchevskoy Volcano. Billowing clouds of water vapor and minor amounts of ash rise from a new fissure that sliced open on the southwestern flank, eventually producing a lava flow. Photograph by Yu. Demyanchuk, IVS, April 9, 2010.

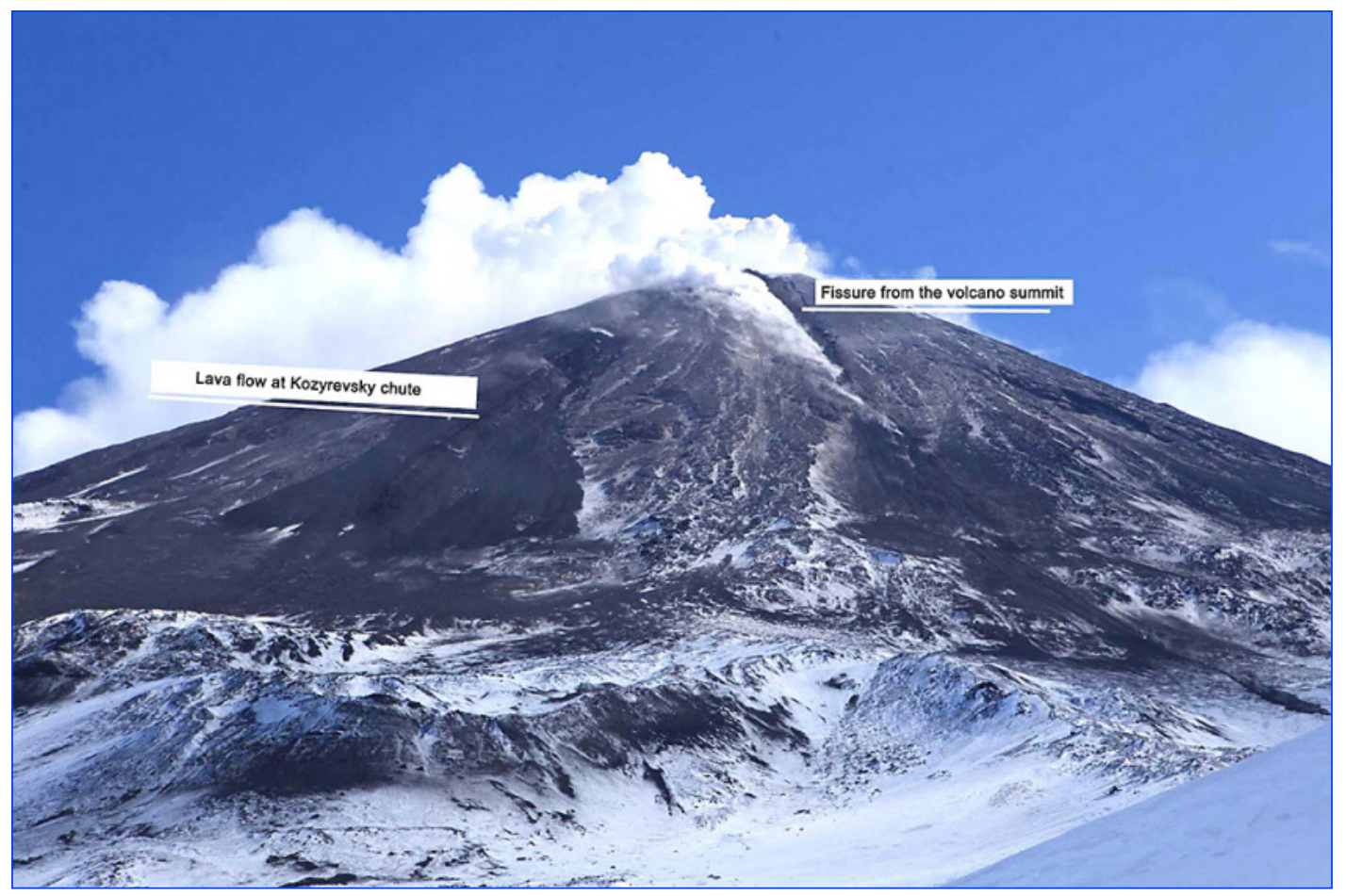

Figure 26. View of the southwestern flank of Klyuchevskoy Volcano showing the new fissure (steaming) and adjacent active lava flow filling the Kozyrevsky chute. Photograph by Yu. Demyanchuk, IVS, April 9, 2010. 


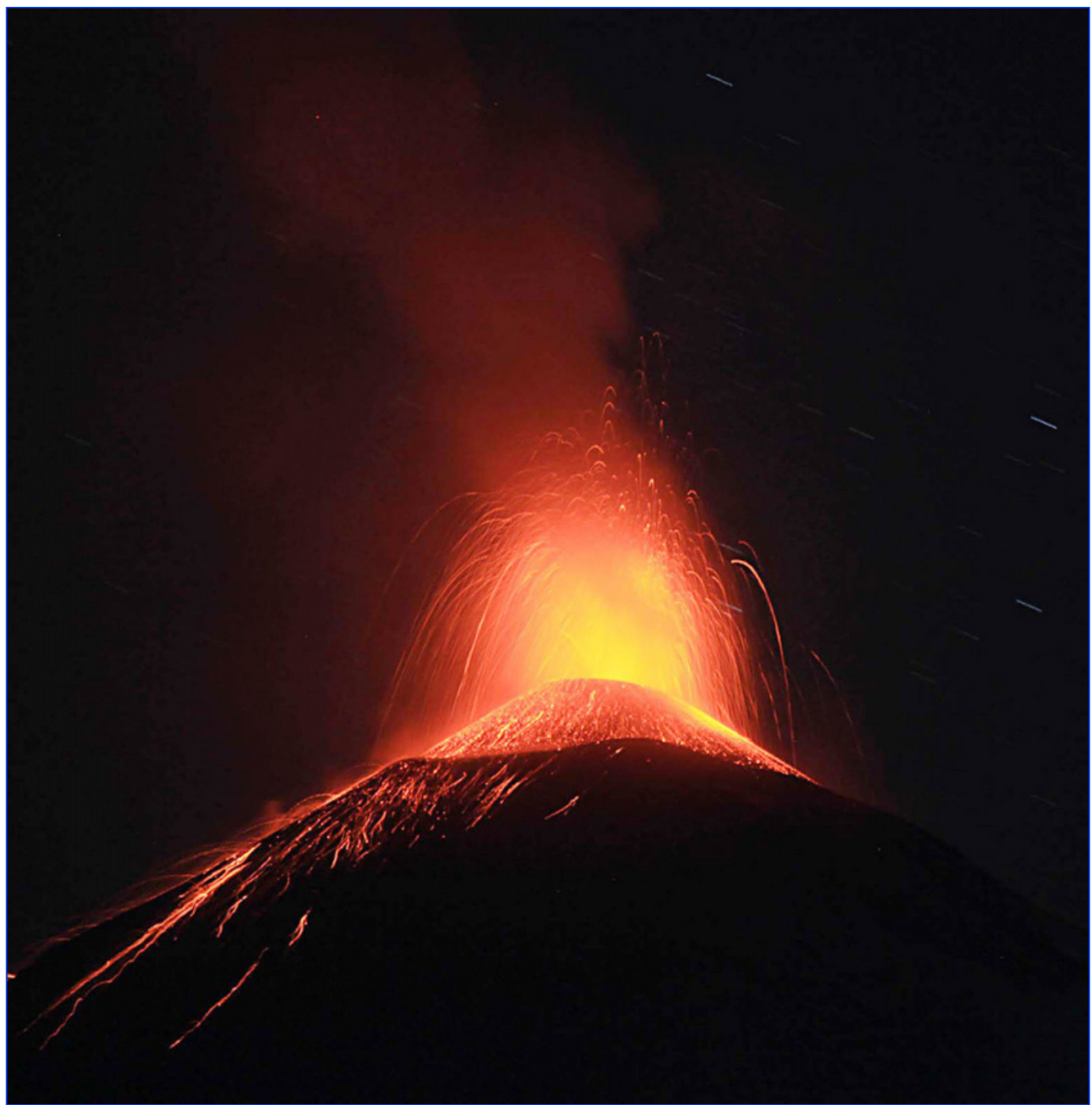

Figure 27. Strombolian activity at the summit of Klyuchevskoy Volcano. Note the incandescent slopes of the growing cinder and spatter cone within the summit crater. Photograph by Yu. Demyanchuk, IVS, September 2, 2010.

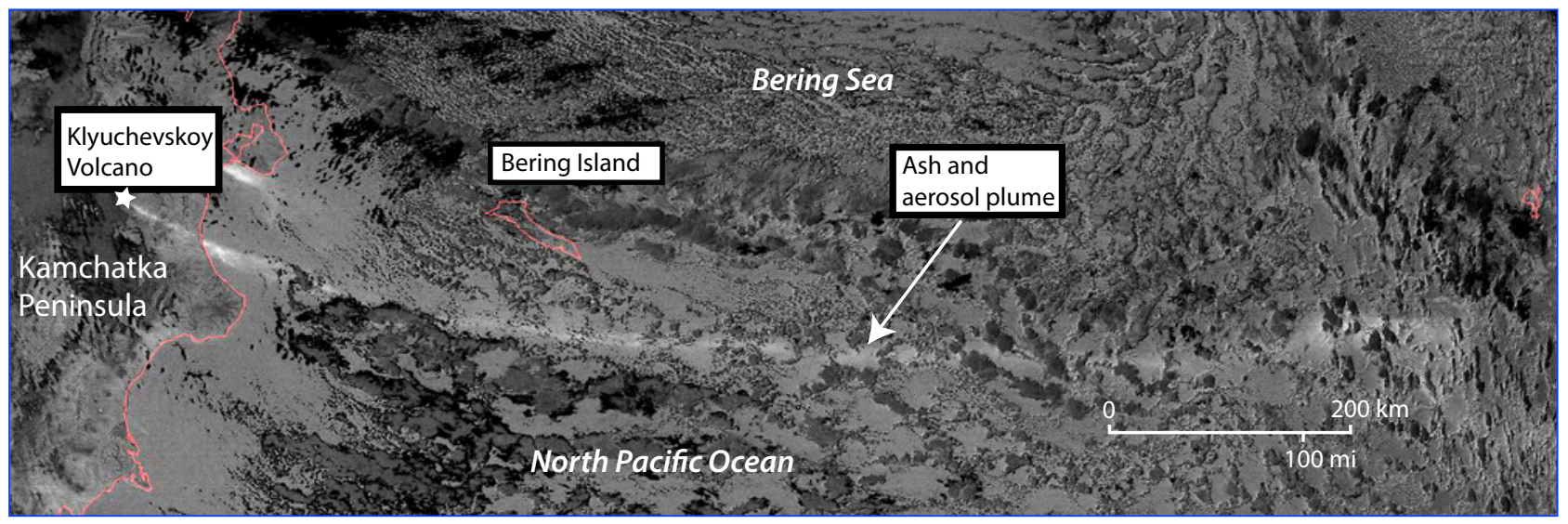

Figure 28. AVHRR satellite image showing tremendous downwind extent of the Klyuchevskoy ash and gas plume at 18:04 UTC on October 31,2010 . North is up; scale is approximate. 


\section{Bezymianny Volcano}

CAVW\# 1000-25-

$55^{\circ} 58^{\prime} \mathrm{N} 160^{\circ} 36^{\prime} \mathrm{E}$

$2,882 \mathrm{~m}(9,455 \mathrm{ft})$

Kamchatka Peninsula, Russia

\section{INTERMITTENT LAVA DOME GROWTH AND EXPLOSION}

A significant short-lived explosion and ash cloud in August

Lava dome growth at Bezymianny continued throughout 2010. The volcano was assigned Aviation Color Code YELLOW from January 1 until February 7. Typically, a fumarolic plume rose above the actively growing dome and seismicity was at or slightly above background (fig. 29). A thermal anomaly at the approximate position of the lava dome complex was common in satellite images reflecting nearly continuing effusion of viscous lava.

Analysis of satellite data indicated that a strong explosive event occurred from 23:42 UTC February 5 until 01:58 UTC February 6. Dense cloud cover precluded detection of ash clouds on satellite images, but based on this event, KVERT upgraded the Aviation Color Code to ORANGE on February 7 at 23:30 UTC. At the same time, the size and intensity of the thermal anomaly over Bezymianny increased (fig. 30). Strong seismicity associated with the eruption of neighboring Klyuchevskoy Volcano made it impossible to discern Bezymianny seismicity. Evidence for an explosion in early February included observation of strong fumarolic activity, often seen at the end of an explosive event, on February 13 and ash deposits on the slopes of the volcano seen in an TERRA ASTER image from March 10, 2010. The strong thermal anomaly $\left(60-50^{\circ} \mathrm{C}\right)$ stayed until mid-February and then gradually decreased to negative values; the Aviation Color Code was changed to YELLOW on February 11.

Another increase in the size and temperature of the thermal anomaly over the lava dome was detected at satellite images on May 19. Based on this, KVERT forecast an explosive event to occur between May 21 and June 10. The Aviation Color Code was changed to ORANGE on May 24 in anticipation of this explosion.
Based on interpretation of seismicity, the expected explosive event occurred on May 31 and consisted of several pulses. The main phase occurred between 12:34 and 12:50 UTC followed by a second period of explosion about 17:00 UTC. The Aviation Color Code was changed to RED on May 31 at 20:45 UTC. Ash from the initial explosion rose about $10 \mathrm{~km}$ (33,000 ft) ASL and plumes stretched $250 \mathrm{~km}$ (150 mi) to the west (fig. 31). Ash fall occurred in Kozyrevsk. Ash from later explosions on May 31 rose above $10 \mathrm{~km}$ (33,000 ft) ASL and drifted north-northeast for about $160 \mathrm{~km}$ (100 mi). Over the next 4 days, discrete ash and gas clouds drifted more than $700 \mathrm{~km}$ (430 mi) from the northern area of the Kamchatka Peninsula southwest and later south over the Pacific Ocean to the northern Kuriles Islands.

After this period of activity, the Aviation Color Code was changed to ORANGE on June 1 and YELLOW on June 3 where it remained for the rest of the year. According to observations by S. Ushakov (IVS) in August, pyroclastic flow deposits from the May 31 event extended $5.5 \mathrm{~km}$ (3.4 mi) down the southern slope of the volcano. Viscous lava that has been effusing from the summit lava dome complex intermittently since 2006 soon extended about $1 \mathrm{~km}$ (3,300 ft). Moderate levels of fumarolic activity from the lava dome continued through the remainder of the year.

On March 30, 1956, Bezymianny's current period of eruption began with a catastrophic flank failure, directed blast, pyroclastic flows, and mud flows (Gorshkov, 1959; Bogoyavlenskaya and others, 1985). Since then, lava extrusion has produced a dome that periodically produces powerful vertical ash emission events, pyroclastic flows, and short-lived but far-traveled ash clouds (Girina and others, 1993; Carter and others, 2007). 


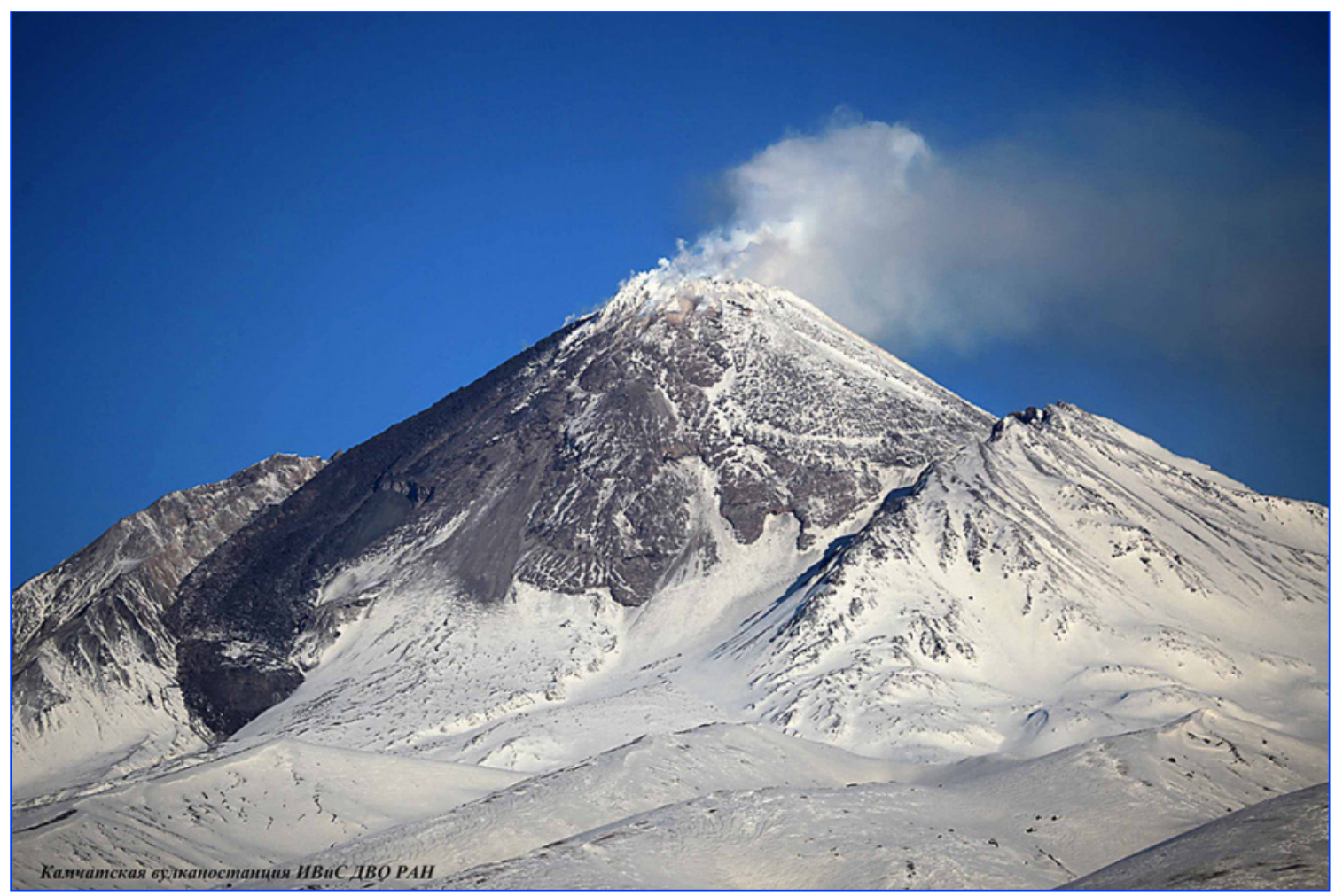

Figure 29. Bezymianny Volcano and the active lava dome, here producing a fumarolic plume. Photograph by Yu. Demyanchuk, IVS, April 19, 2010.

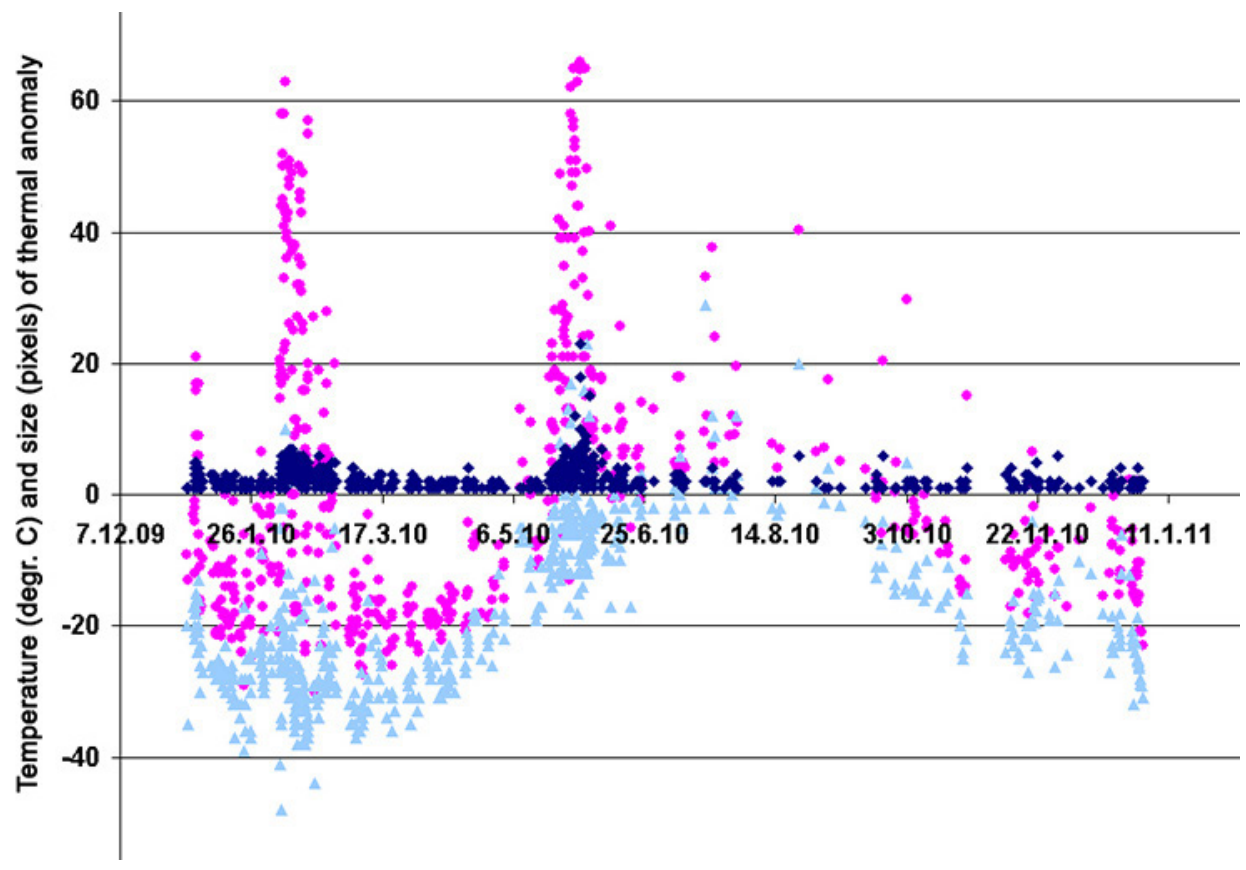

Figure 30. Plot of the maximum AVHRR satellite brightness temperature (pink dots; degrees $\mathrm{C}$ ) and the number of elevated-temperature pixels (dark diamonds), and background temperatures (blue triangles) for observed thermal anomalies over the summit area of Bezymianny Volcano (December 7, 2009 through January 11, 2011). 


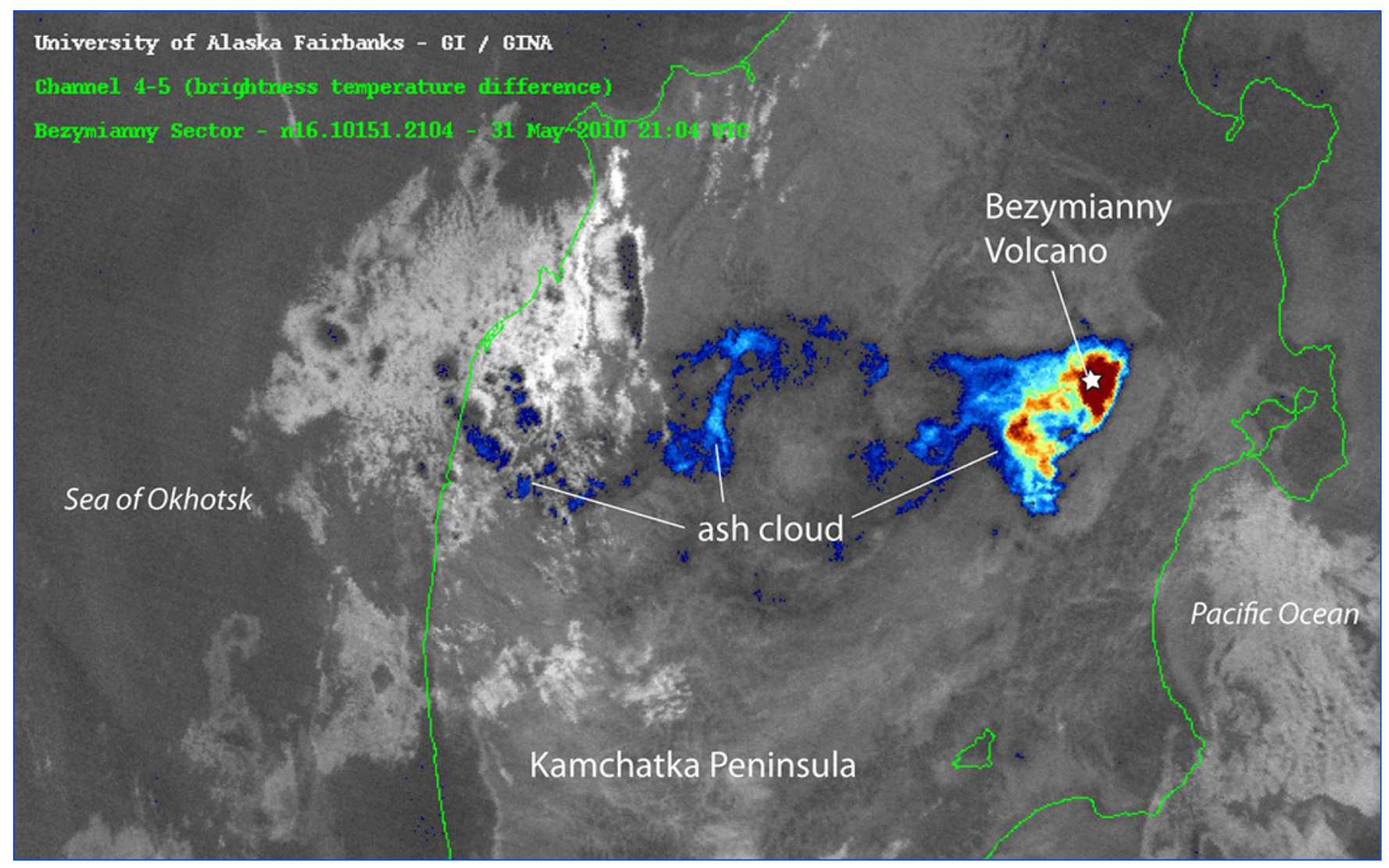

Figure 31. AVHRR satellite image of Kamchatka on May 31, 2010, at 21:04 UTC showing color-enhanced ash cloud from Bezymianny Volcano nearly 9 hours after the onset of explosive activity. In this image, ash from the earliest explosions on May 31 is already over western Kamchatka. A dense ash cloud remains directly over the volcano (star) at the time of this image indicating continuing ash emission. 


\section{Kizimen Volcano}

CAVW\# 1000-23-

$55^{\circ} 08^{\prime} \mathrm{N} 160^{\circ} 19^{\prime} \mathrm{E}$

$2,485 \mathrm{~m}(8,151 \mathrm{ft})$

Kamchatka Peninsula, Russia

\section{INCREASED SEISMICITY, EXPLOSIVE ERUPTION}

2010 saw the onset of explosive activity at Kizimen Volcano, a remote stratocone in east-central Kamchakta, inactive for nearly a century (Piip, 1946).

Monitored by a single seismic station operated by KBGS RAS, seismicity at Kizimen was considered moderate for most of 2010. On November 20, observers in the field noted several new fumaroles at the summit and on the southwestern flank of the volcano. A small amount of fine-grained tephra-produced during the opening of these new fumaroles - covered the top and southwestern flank of the volcano. Based on this departure from background activity, KVERT upgraded the Aviation Color Code from GREEN to YELLOW on November 25.

Within weeks of the appearance of new fumaroles, an explosive eruption began on December 9, 2010. Relatively strong seismicity began at 00:03 UTC followed by volcanic tremor at 02:00 UTC. A lucky commercial aircraft passenger, D. Page, flying from Vancouver, B.C. to Seoul, Korea, witnessed and photographed the passage of pyroclastic flows, one after another, down the southeastern flank of the volcano. Ash elutriate from these pyroclastic flows rose 3-4 km ASL (fig. 32).

Phreatic explosions occurred where hot $\left(800-900{ }^{\circ} \mathrm{C}\right)$ pyroclastic deposits encountered snow. Melting snow combined with debris to form lahars in the Left Shchapina River. Satellite images from 01:10 UTC on December 10 showed a strong thermal anomaly (7-24 pixels with a temperature of $64-65^{\circ} \mathrm{C}$ ) in Kizimen summit area. KVERT upgraded the Aviation Color Code to ORANGE on December 10 at 10:30 UTC.

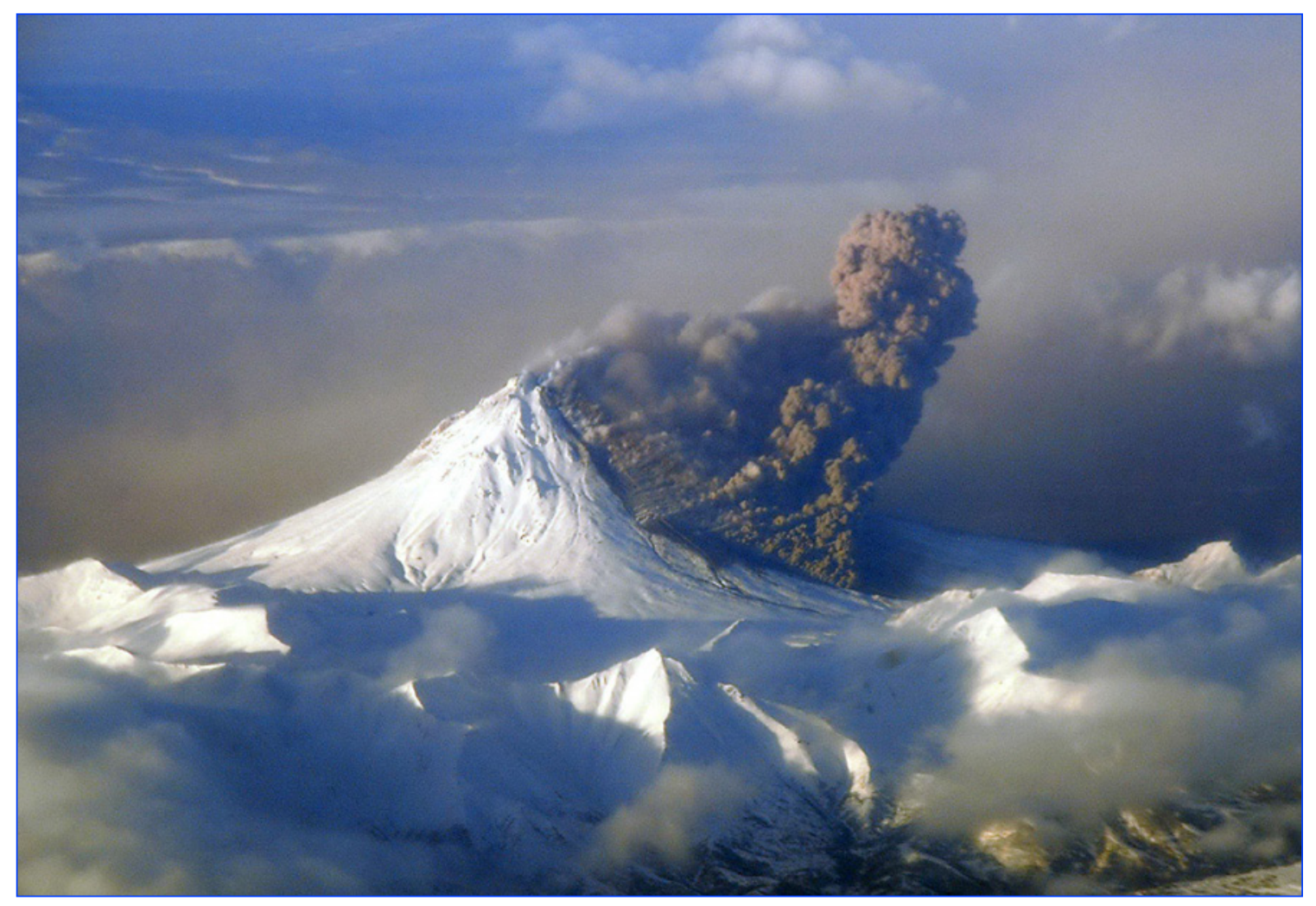

Figure 32. Oblique aerial view, towards the northeast, of the early phase of the 2010 Kizimen eruption as viewed from a commercial airliner. A column of ash is rising from hot pyroclastic avalanches down the southeastern flank of the volcano. Photograph by D. Page, December 9, 2010, used with permission. 
The eruption intensified on December 12 and a powerful explosion occurred from 19:49 to19:57 UTC sending ash to $10 \mathrm{~km}(33,000 \mathrm{ft})$ ASL according to the Tokyo VAAC. The ash plume extended about $500 \mathrm{~km}$ (310 mi) northwest from the volcano and combined snow and ash fall occurred in Kozyrevsk from 21:00 until 21:30 UTC and Tigil from 23:30 to 24:00 UTC. The thickness of ash mixed with snow was about $0.5 \mathrm{~cm}$ (0.2 in.). The Aviation Color Code was changed to RED from 23:30 UTC on December 12 through December 13 (23:15 UTC) when the Aviation Color Code changed to ORANGE. According to observers from Cordon "Ipuin" of the Kronotsky Nature Reserve, sometime after the explosive events on December 12, the water level in the Levaya Shchapina River rose by 60 cm (24 in.). This increase in water level was caused by lahars entering the river. As activity diminished in intensity, ash emission continued (fig. 33) but did not exceed 5-6 km (16,000-20,000 ft) in altitude. Ash plumes stretched for hundreds of kilometers in different directions from the volcano and ash falls occurred in many Kamchatkan settlements west, northwest, and south of the volcano.

Seismic activity increased again on December 26 and based on the character of the seismicity, it is likely that small ash explosions and additional hot pyroclastic avalanches resumed. Satellite images captured ash plumes extending about $140 \mathrm{~km}$ (90 mi) west from the volcano about $4 \mathrm{~km}$ (13,000 ft) ASL on December 27. A thermal anomaly over the summit area persisted. The Aviation Color Code was changed to RED from December 27 through December 29 and again on December 31 during periods of higher seismicity and stronger ash production.

On December 31, the Kizimen ash cloud reached Petropavlovsk-Kamchatsky and Yelizovo; the cloud was light brown in color, diffuse, and extended over the city and Yelizovo Airport at an altitude of 4-4.5 km (13,000-15,000 ft) ASL. A dusting of ash (less than $1 \mathrm{~mm}$ or $1 / 25$ th of an inch) fell in the cities of Petropavlovsk-Kamchatsky and Yelizovo; this ash fall prevented landings and departures from Yelizovo Airport on December 31-January 1. The explosive eruption of Kizimen continued in 2011. Analysis of InSAR imagery by Ji and others (2013) later demonstrated that at least $6 \mathrm{~cm}$ (2.4 in.) of deformation occurred between September 2008 and September 2010 just before eruption onset.

Kizimen is located on the western slope of the southern part of Tumrok ridge $265 \mathrm{~km}$ (165 mi) northeast of Petropavlovsk-Kamchatsky (fig. 21). The northwestern flank of the volcano drains to the valley of the Levaya Shchapina River. Details of the history of Kizimen eruptions are unknown. Partial information about an eruption in 1928-1929 suggests it was likely a moderate explosive (or explosiveeffusive) event (Piip, 1946). Tephrochronological data have identified several catastrophic eruptions in the Holocene (Melekestsev and others, 1995). Long-lived, active fumarolic areas on the upper flanks are described in Kirsanova and others (1983).

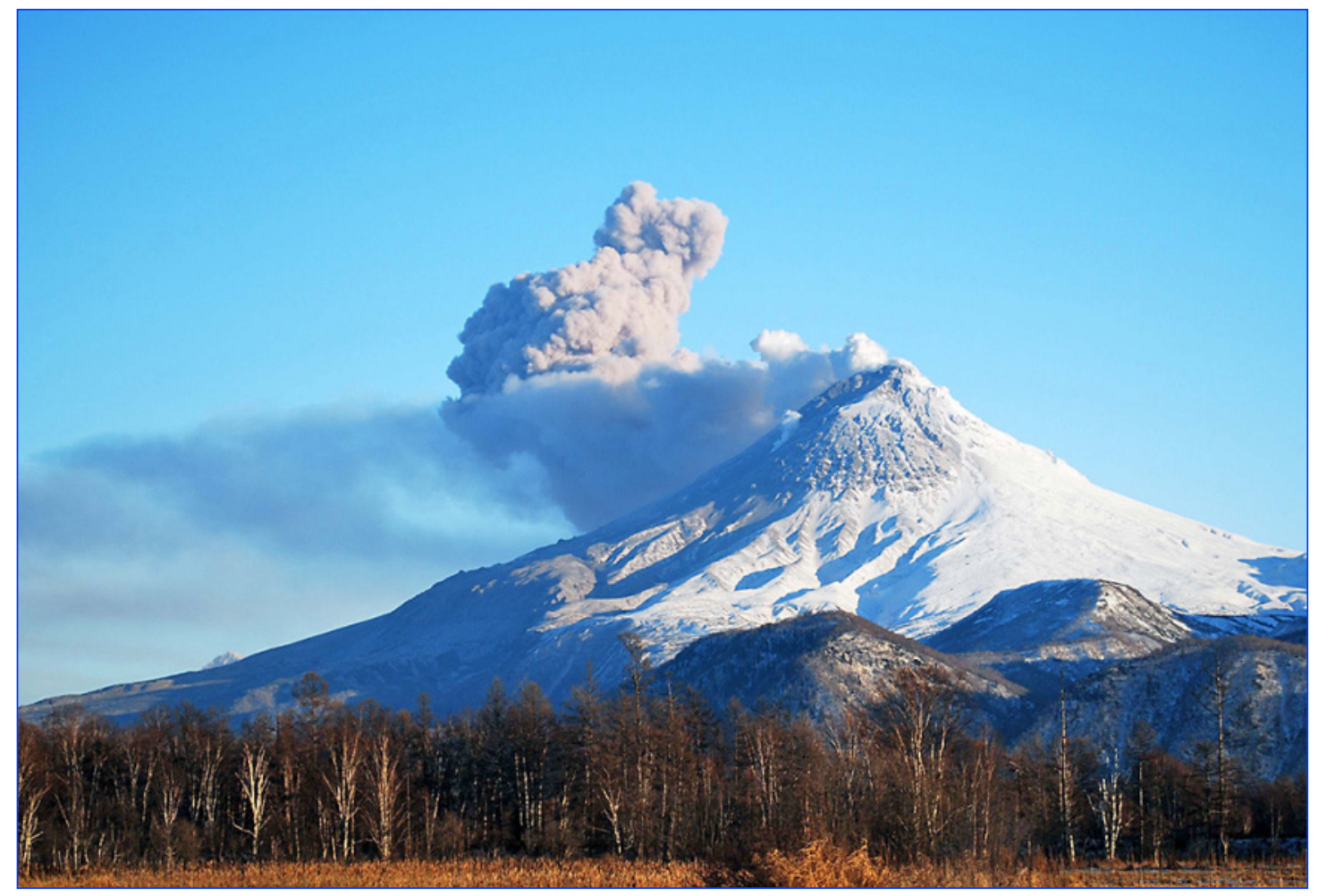

Figure 33. Ash-covered eastern flank of Kizimen Volcano following the strong explosions of December 12, 2010. A column of ash rises above a recent pyroclastic flow on the southeastern flank. Photograph courtesy KVERT. 


\section{Karymsky Volcano}

CAVW\# 1000-13-

$54^{\circ} 03^{\prime} \mathrm{N} 159^{\circ} 27^{\prime} \mathrm{E}$

$1,486 \mathrm{~m}(4,875 \mathrm{ft})$

Kamchatka Peninsula, Russia

\section{STROMBOLIAN / VULCANIAN ERUPTION CONTINUES INTERMITTENTLY}

Explosions, low-level ash clouds

Karymsky Volcano remained active throughout 2010, continuing to produce occasional ash clouds during Vulcanian or Strombolian explosions from the summit crater (figs. 3435). These ash clouds did not exceed $8 \mathrm{~km}(26,000 \mathrm{ft})$ ASL based on interpretation of the relationship of seismic intensity and column height determined by scientists at KBGS. Significant ash clouds in 2010 occurred on March 28, April 28, June 11, and June 29. Spatter and bombs during some explosions produced agglutinate flows on the flanks of the Karymsky cone.

KVERT assigned Aviation Color Code ORANGE to Karymsky from January 1 through February 25, when decreasing seismicity prompted a downgrade to YELLOW. Beginning on March 25, seismicity increased again in intensity and a strong thermal anomaly was detected in satellite images. The Aviation Color Code was changed to
ORANGE on March 29 where it remained through the end of the year. Small to moderate explosions continued and ash plumes extending up to several hundred kilometers downwind were noted by pilots and in satellite imagery.

Karymsky is the most active volcano on the Kamchatkan Peninsula. Explosive and effusive-explosive eruptions of andesitic tephra and lava flows alternating with periods of repose are typical of Karymsky (Ivanov and others, 1991). The current phase of unrest began in mid-April 1995 with increasing seismicity that led to an explosive eruption that began on January 1, 1996. Initial eruptive activity occurred simultaneously at Karymsky Volcano and from a vent at the northern part of Karymsky Lake a distance of about $10 \mathrm{~km}$ (6.2 mi; Fedotov, 1998; Belousov and Belousova, 2001). Since then, periods of explosive eruptions of ash and blocks have alternated with periods of lava-flow production. 


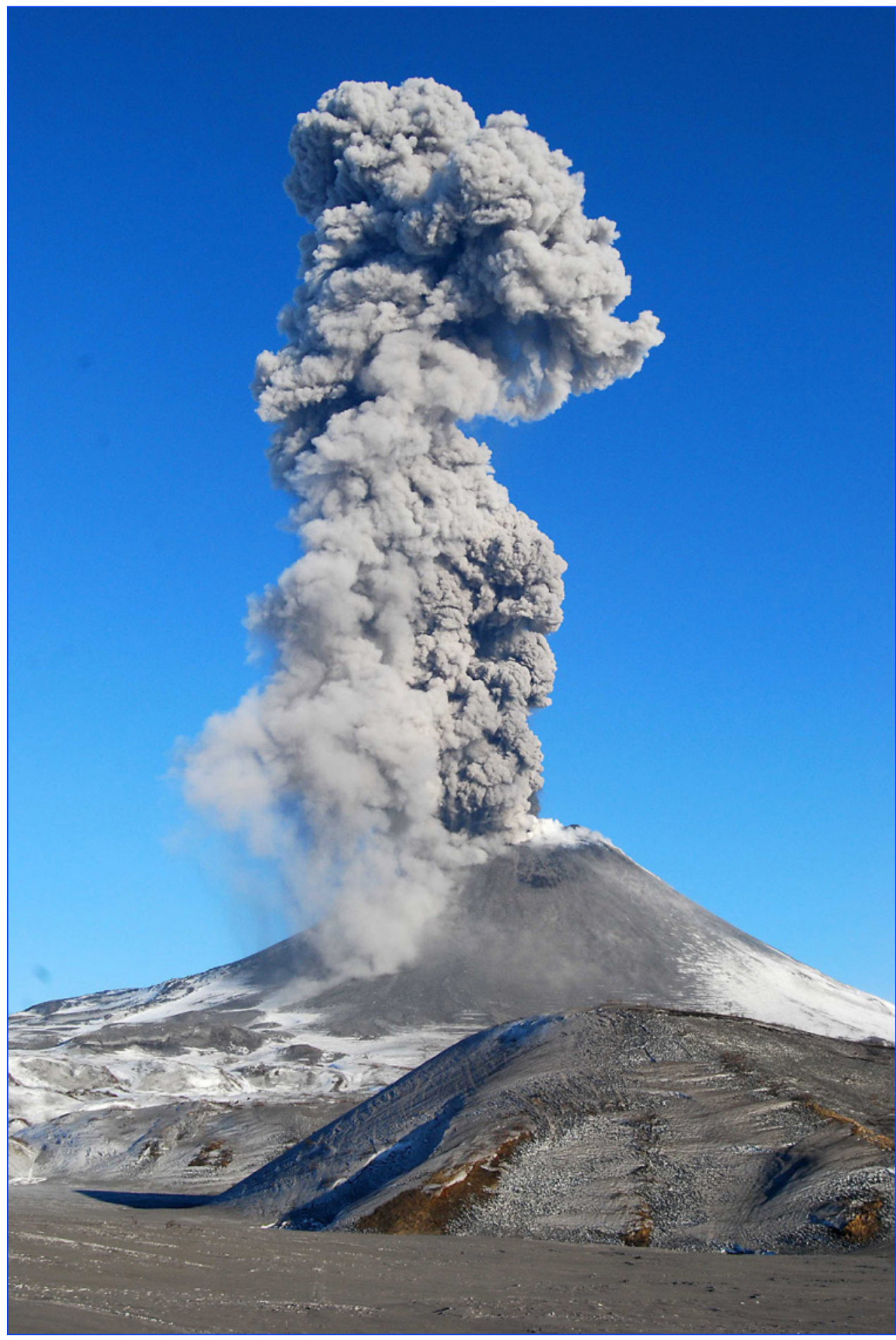

Figure 34. Typical Vulcanian explosion at Karymsky. Photograph by A. Manevich, IVS, April 18, 2010. 


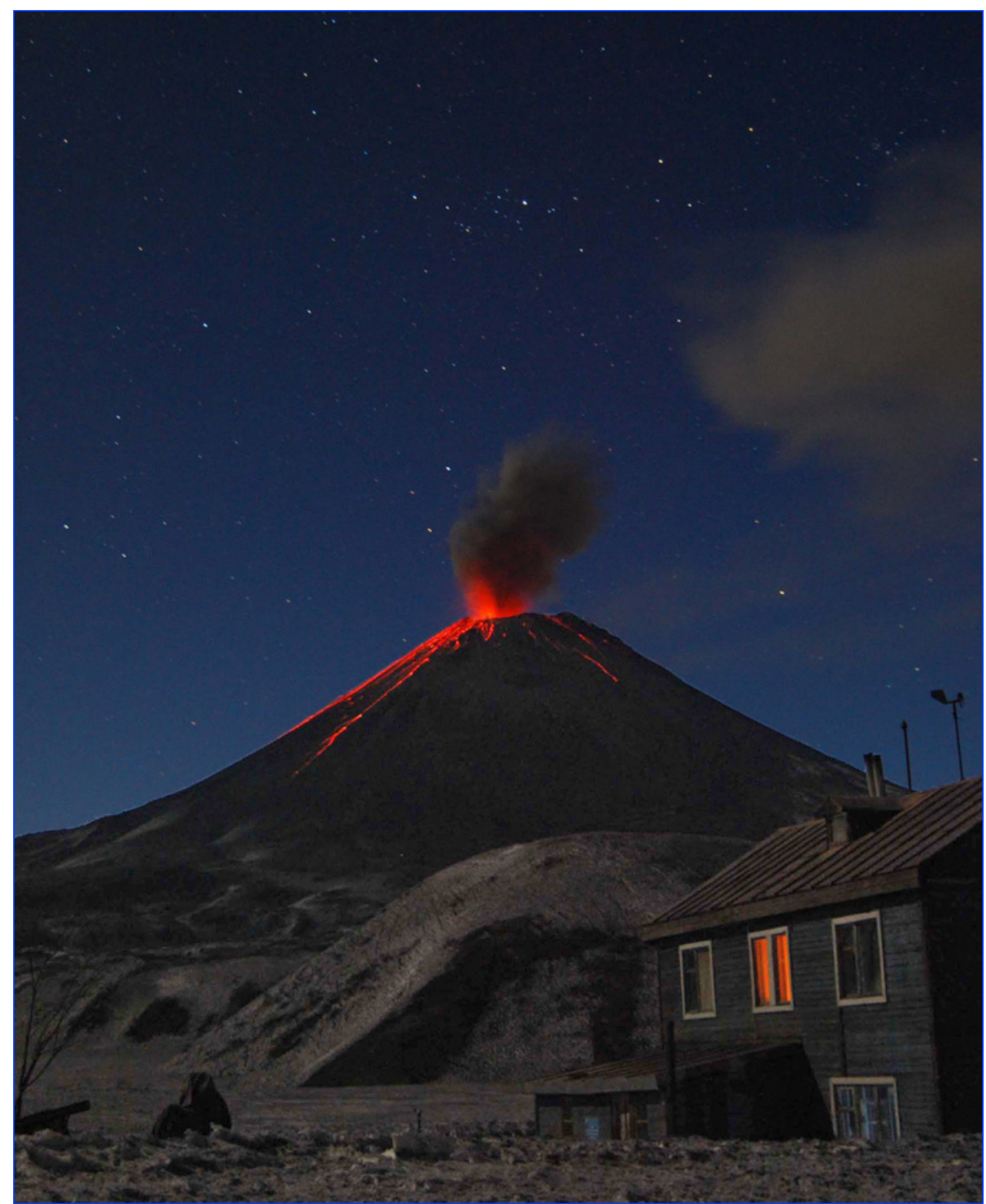

Figure 35. Typical Strombolian activity at Karymsky. Photograph by A. Manevich, IVS, April 21, 2010. 


\section{Gorely Volcano}

CAVW\# 1000-07-

$52^{\circ} 33^{\prime} \mathrm{N} 158^{\circ} 02^{\prime} \mathrm{E}$

$1,829 \mathrm{~m}(6,001 \mathrm{ft})$

Kamchatka Peninsula, Russia

\section{INCREASED SEISMICITY, HEAT, DEGASSING}

No eruption

Thermal and seismic activity at Gorely Volcano began to increase in 2007 (McGimsey and others, 2011) and remained elevated for several years. Beginning in June 2010, seismicity and fumarolic output further increased significantly. According to KBGS RAS, on June 10, the magnitude of continuous volcanic tremor rose sharply and remained high through the remainder of the year (fig. 36).

When visited from June 15 to 22 , field observers noted a new fumarolic source inside the Gorely crater. This fumarole had a vent about $20 \mathrm{~m}$ (65 ft) in diameter that emitted a powerful plume of high-temperature gas emissions (fig. 37). Temperatures were measured as high as $870^{\circ} \mathrm{C}$ (Ovsyannikov, and Chirkov, 2010). Based on this dramatic increase in surface thermal manifestation accompanied by an increase in tremor, KVERT upgraded the Aviation Color Code to YELLOW on June 24 where it remained for the rest of the year.

Nearly continuous, powerful plumes were produced by the new Gorely fumarole throughout 2010. At times, the column of gas and water vapor rose as high as 3.5 km (11,500 ft) ASL (ig. 38) and drifted downwind up to $150 \mathrm{~km}$ (90 mi). Reflection of incandescence off clouds at night produced a beautiful glow over the volcano (fig. 39). Intermittent thermal anomalies centered over the crater were detected in satellite images. These plumes were observed with OMI sensors indicating elevated sulfur dioxide.

Likely due to the increased thermal and gas output from the summit crater, the level of the intracrater lake at Gorely decreased over the course of the year. Beginning in mid-November, activity began to decrease, although tremor remained elevated through the year's end.

Gorely Volcano consists of a complex set of five overlapping stratovolcanoes within a late Pleistocene caldera (Siebert and others, 2010). Many of the several dozen flank craters contain lakes. Historical eruptions have been dominated by Vulcanian and phreatic explosions; Siebert and others (2010) list 13 possible eruptions since about 1700, the most recent in 1986.

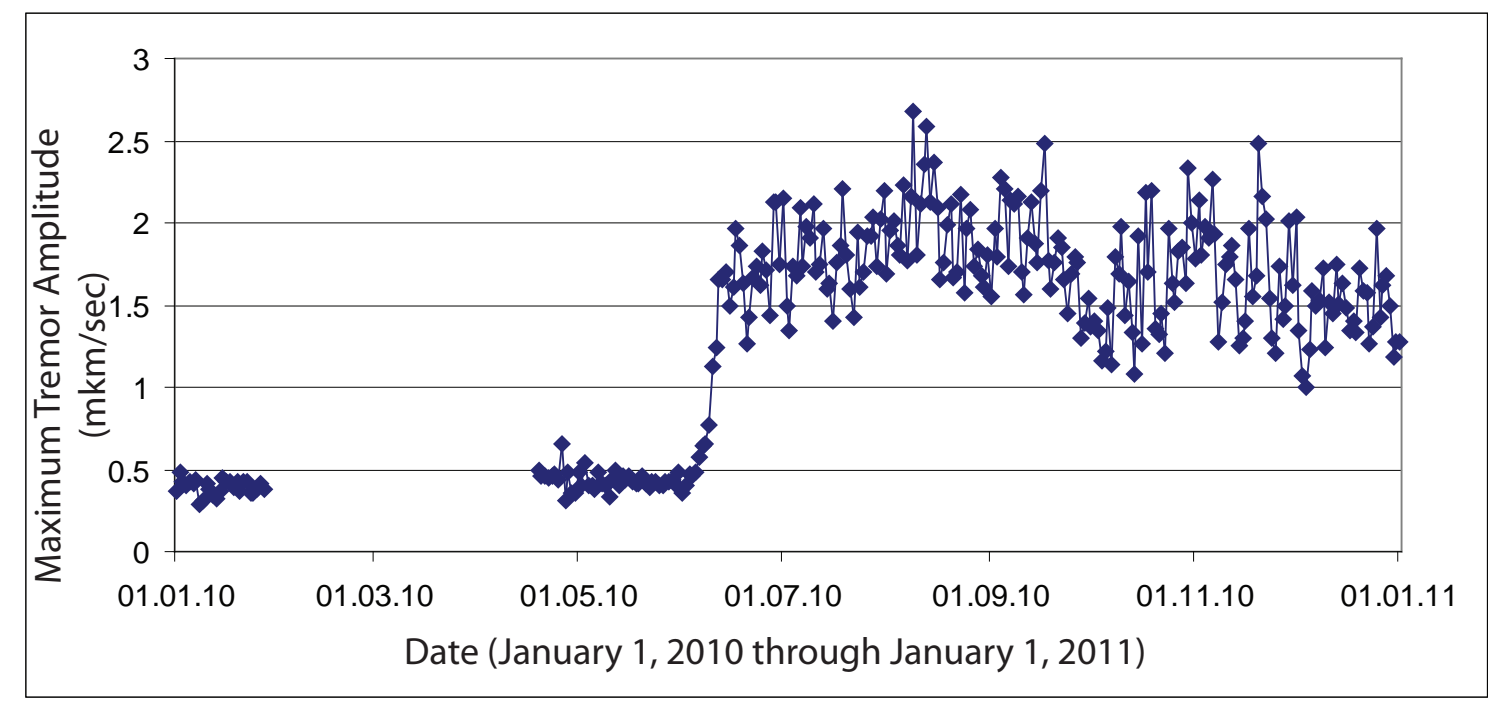

Figure 36. Plot showing amplitude of volcanic tremor in June 2010 of Gorely Volcano. Note the sudden increase in tremor amplitude on June 10, 2010. Figure courtesy Sergey Senyukov, KBGS RAS. 


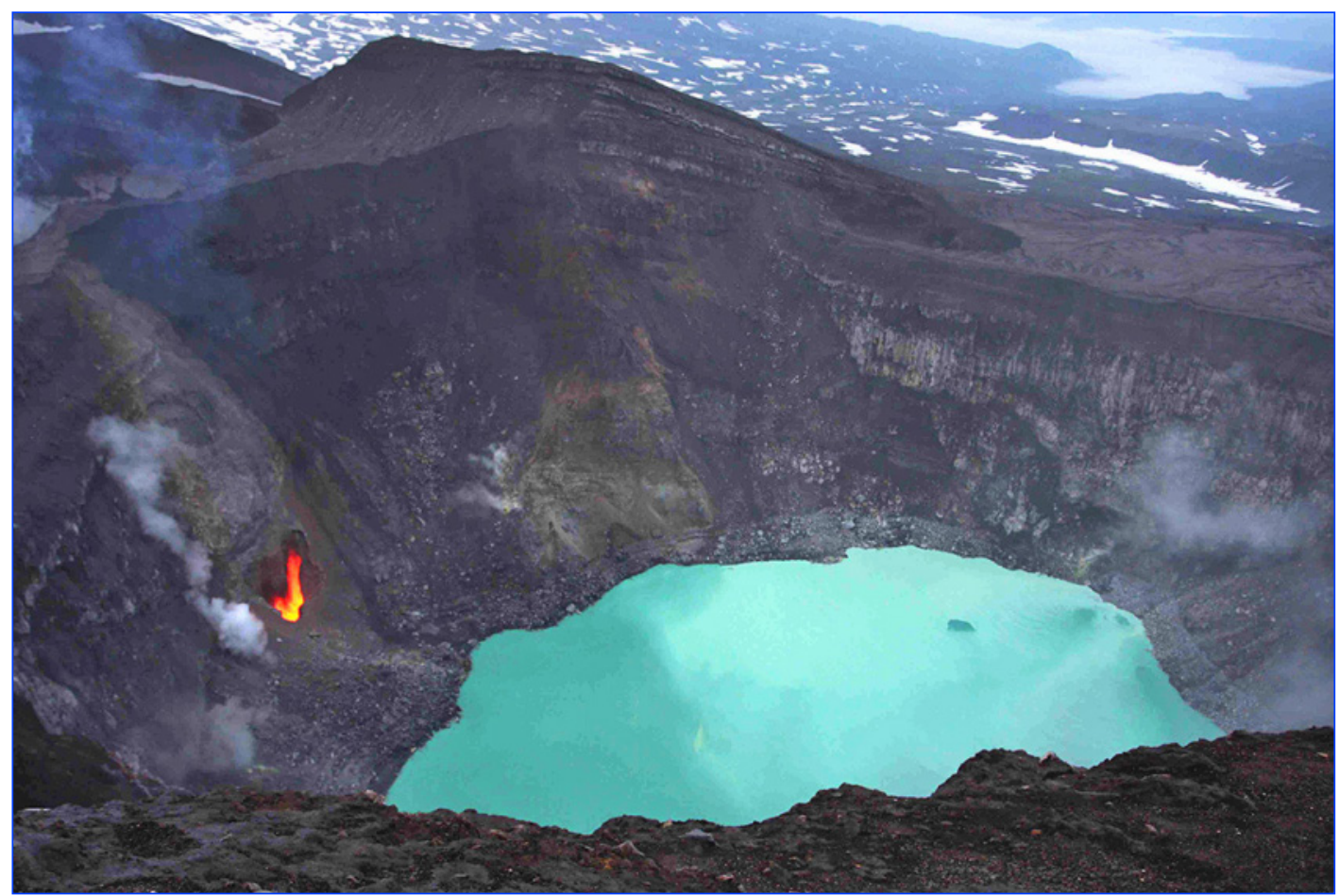

Figure 37. Incandescence visible in the 20 -m-wide $(65 \mathrm{ft})$ orifice of a newly formed fumarole inside the Gorely crater. Photograph by E. Safonova, July 9, 2010, used with permission.

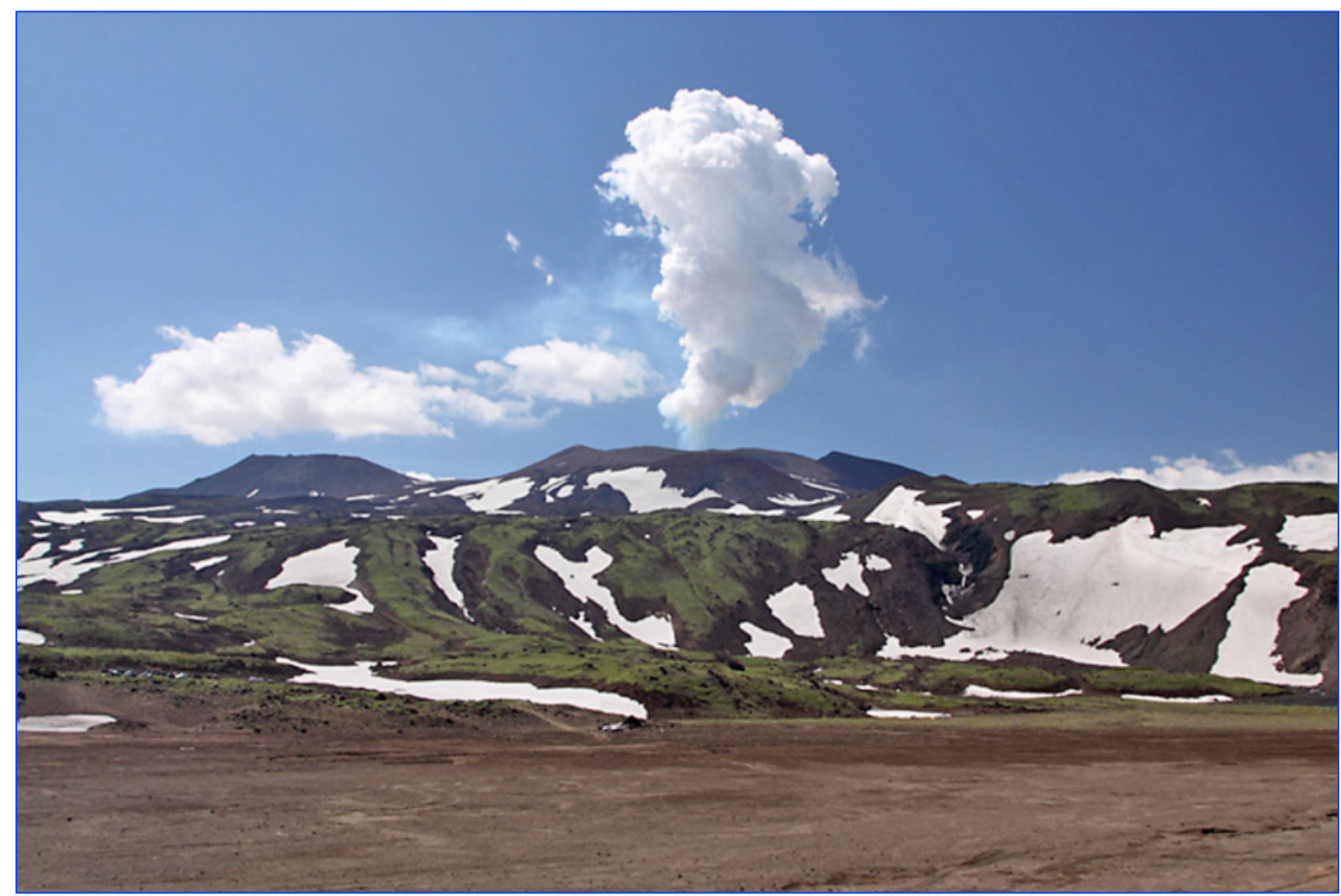

Figure 38. Fumarolic plume from Gorely volcano. Photograph by A. Gromov, July 2010, used with permission. 


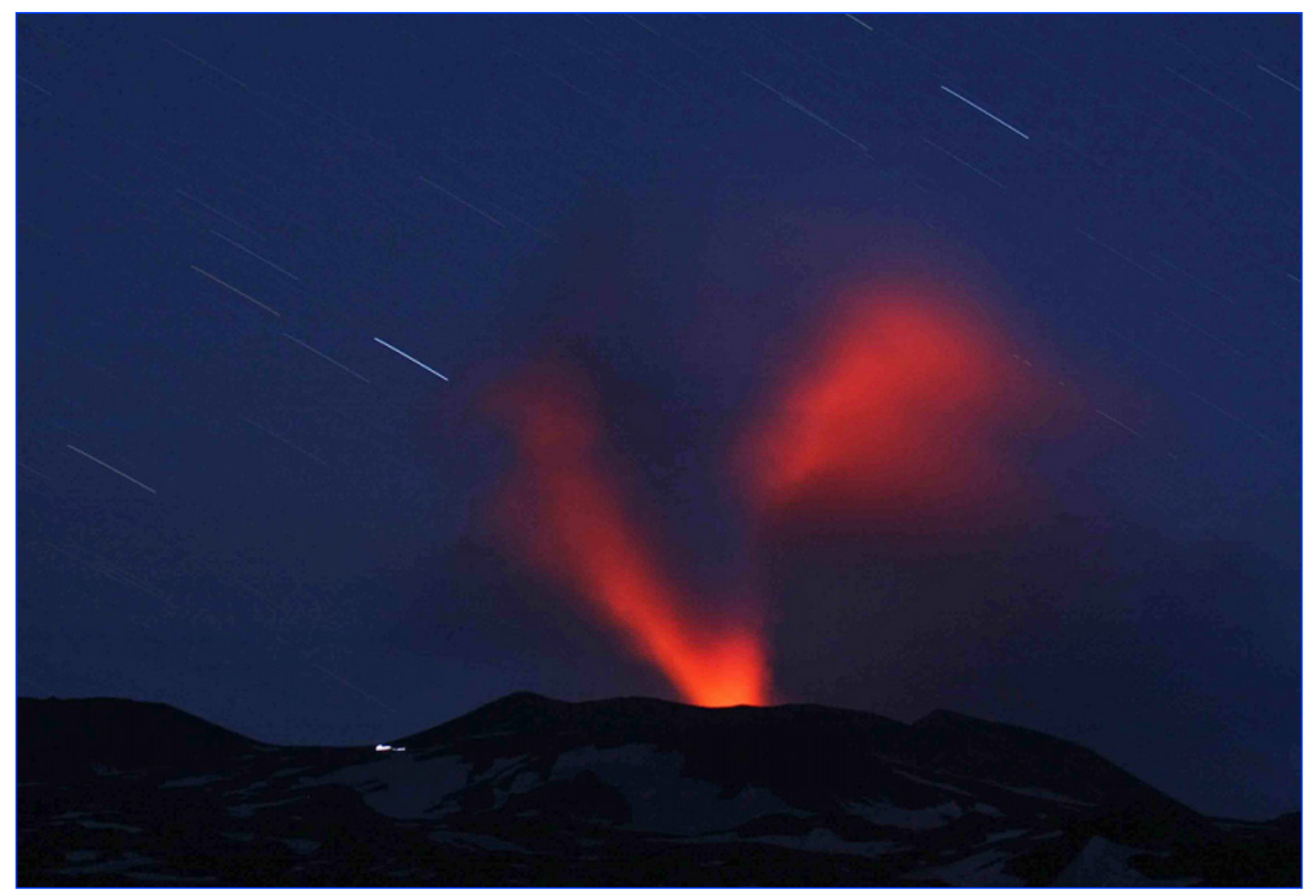

Figure 39. Reflection of incandescence from the hot gas plume exiting the crater of Gorely volcano. Photograph by E. Safonova, July 9, 2010, used with permission. 


\section{Volcanic Activity, Central and Southern Kurile Islands, Russia}

The Institute of Marine Geology and Geophysics (IMGG), the host institute for the Sakhalin Volcanic Eruption Response Team (SVERT; Neal and others, 2009a), reports on activity at central and southern Kurile Island volcanoes (fig. 40). SVERT uses available satellite imagery of the Kurile Islands, periodic (every 10 days) reports of seismic data from Kunashir and Iturup Islands, and visual observations from residents on several southern Kurile Islands. As funding allows, they conduct field visits and investigations in the summer. By agreement between SVERT and KVERT, the northernmost Kurile Islands of Paramushir and Alaid are under the reporting jurisdiction of KVERT.

2010 was a quiet year for Kurile volcanoes. Eruptive activity was documented after the fact at a single volcano, Ekarma.

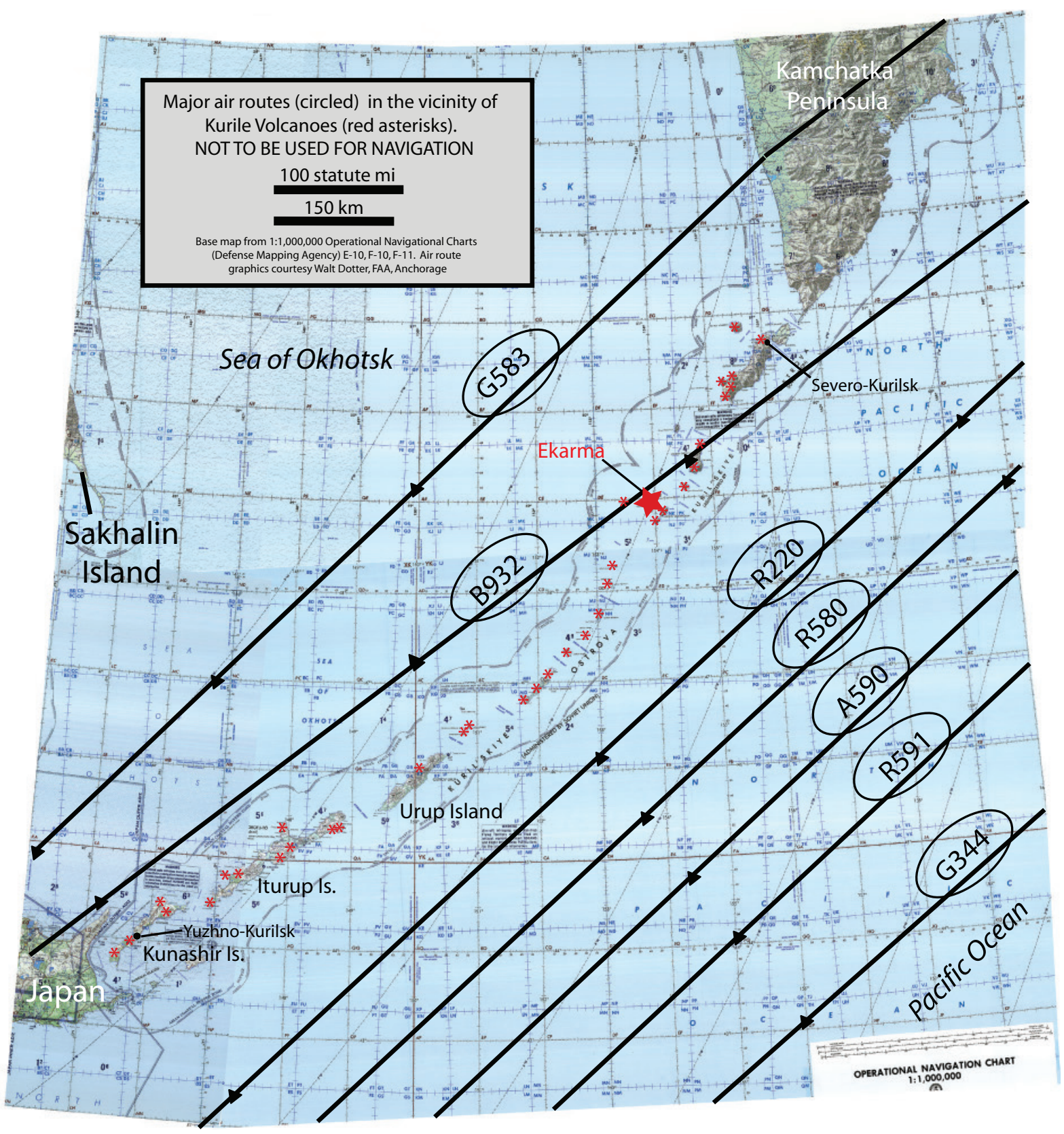

Figure 40. Kurile Island Volcanoes from Neal and others (2008). Volcanoes mentioned in this report are shown by large stars, additional volcanoes shown by red asterisks. Bold black lines are fixed air routes (route identifiers are circled) in the North Pacific and Russian Trans East systems. Black triangles are air navigational fixes. 


\section{Ekarma Volcano}

CAVW\# 0900-27-

$48^{\circ} 57^{\prime} \mathrm{N} 153^{\circ} 56^{\prime} \mathrm{E}$

$1,170 \mathrm{~m}(3,839 \mathrm{ft})$

Ekarma Island, Russia

\section{PHREATIC (?) ERUPTION, LAHAR}

In August 2010, an international expedition to the Central and North Kurile Islands was conducted under the leadership of Alexander Rybin, Chief of the Laboratory of Volcanology and Volcanic Hazards, Institute of Marine Geology and Geophysics, Russian Academy of Sciences, Yuzhno-Sakhalinsk, Russia. The 16 members of the expedition included scientists from the Institutes of Far East Branch Russian Academy of Sciences (Institute of Marine Geology and Geophysics, Institute of Volcanology and seismology, Pacific Institute of Geography) and foreign partners from the University of Alaska Fairbanks and the University of Washington. The objective of the expedition was to study all aspects of the 2009 eruption of Sarychev Volcano (Rybin and others, 2011) and to investigate the history of Raikoke Volcano. During the expedition, news of volcanic activity at Ekarma Volcano briefly interrupted planned fieldwork on Sarychev. This work was carried out with the support of the sailing training vessel "Nadezhda" of G.I. Nevelskoy Marine State University, Vladivostok (ig. 41).

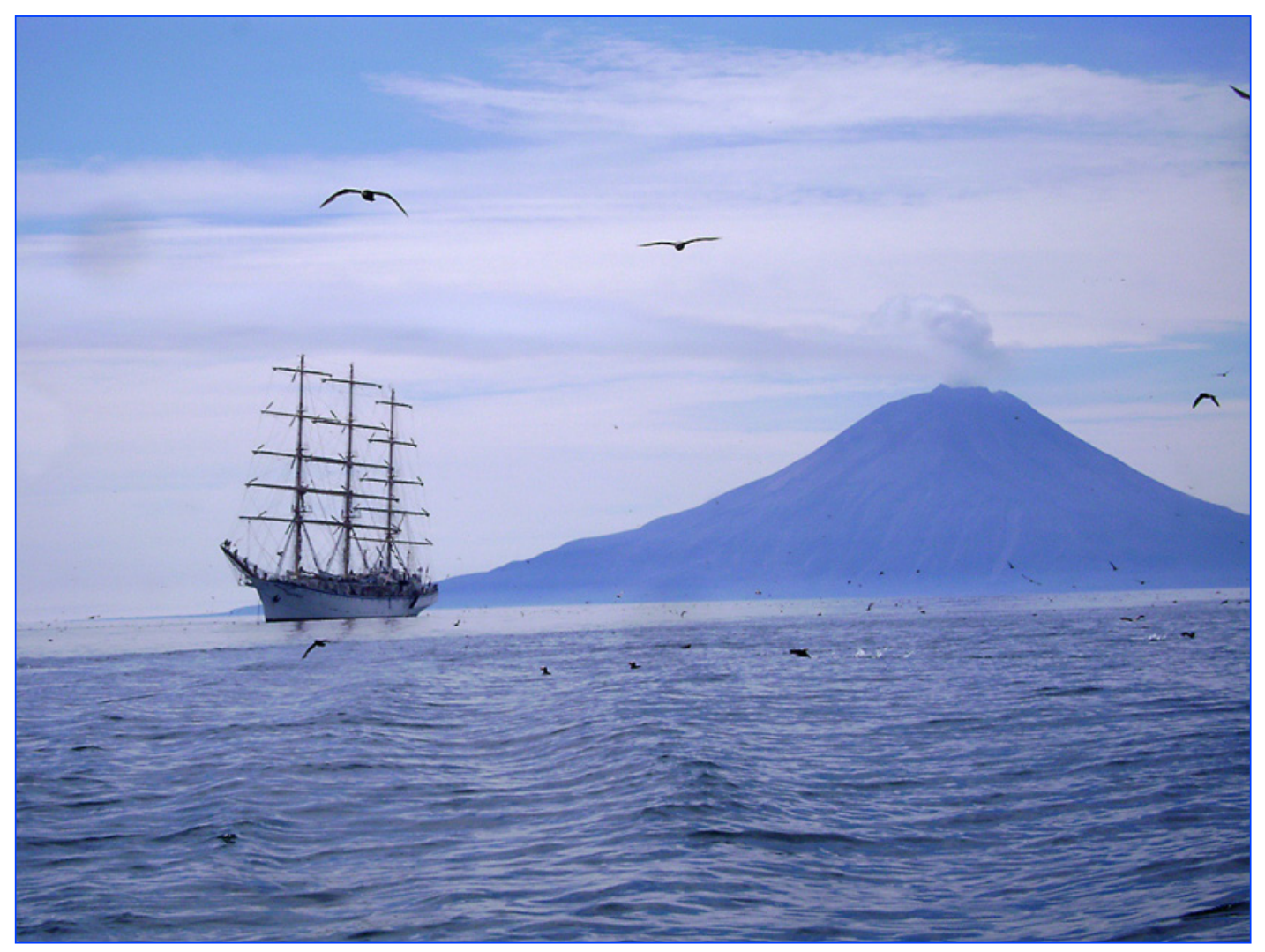

Figure 41. Sailing training vessel "Nadezhda" in front of Ekarma Volcano. Photograph by A. Degterev, summer 2010. 
There are few records of historical activity at Ekarma. On May 24, 1980, a passing ship reported a series of explosions that lasted an hour and a black eruptive column reaching more than $1 \mathrm{~km}(3,300 \mathrm{ft})$ above the summit of the volcano (Ivanov and others, 1981). This is the only mention of recent activity at Ekarma and it remains an uncorroborated account. Since then, there have been no focused volcanological studies on Ekarma. Photographs of the volcano from passing research ships in 2007 and 2008 show no sign of activity (Levin and others, 2009; fig. 42). Analysis of satellite imagery from 2000 through 2008 also shows no sign of volcanic unrest. International Space Station photographs from 2010 show only weak fumarolic activity near the volcano's summit (fig. 43).

Information regarding activity at Ekarma reached the members of the 2010 expedition in late summer. A.S. Neroda, a scientist with the Pacific Institute of Geography FEB RAS, was investigating Kurile sea lions on Skala Dolgaya Island (in the group of Lovushki Islands, $42 \mathrm{~km}$ (26 mi) to the southwest of Ekarma Island) from May 28 through July 11. At the beginning of June, the sea lion researchers noted higher than normal fumarolic activity at Ekarma; photographs from June 13 show three sources of intense steam-gas activity on the southern slope (fig. 44). The lowest site is about $720 \mathrm{~m}$ $(2,360 \mathrm{ft})$ in elevation and was elongate in form, suggestive of a fissure structure with a northeast-southwest orientation. The central site is about $820 \mathrm{~m}(2,690 \mathrm{ft})$ in elevation; the upper site is near the summit of the volcano.
Late on June 16, the research party on Skala Dlinnaya Island, $44 \mathrm{~km}$ (27 mi) southwest of Ekarma, heard thunder. Over the course of about 30-40 minutes, they noted 8-10 distinct peals. Over the next few days, the thunder-like noise was muted and clouds obscured the volcano. Because of bad weather, photographs were not possible until June 29-30 (fig. 44, panels 3-6). By this time, additional point sources of fumarolic activity were visible on the southern slope. In addition, new, light gray flowage deposits were visible downslope from the fumaroles (fig. 44, panel 5). Late on June 30, a cloud of what appeared to be ash enveloped the top of the volcano (fig. 44, panel 6). Winds were to the east and no ash fall occurred on Skala Dolgaya Island.

On August 10, 2010, the scientific crew of the sailing training vessel "STS Nadezhda" observed the significant fumarolic plume from Ekarma Volcano. The vessel was between Raikoke and Matua Islands some $90 \mathrm{~km}$ (55 mi) from Ekarma. For the entire day, a light gray colored column rose from about 500 to $600 \mathrm{~m}$ (1,600 to 2,000 ft) elevation on the southwestern flank of the island; the cloud reached $1-2 \mathrm{~km}$ (3,300-6,600 ft) ASL before being carried downwind (fig. 45).

From August 11 to 23, 2010, the volcanologic expedition worked on Matua Island 105 km (65 mi) from Ekarma; participants were able to view Ekarma from Dvoinaya Bay on Matua Island on good visibility days (August 14 and 22). Both times, the fumarolic plume rose about 1,600 m (5,000 ft) ASL.

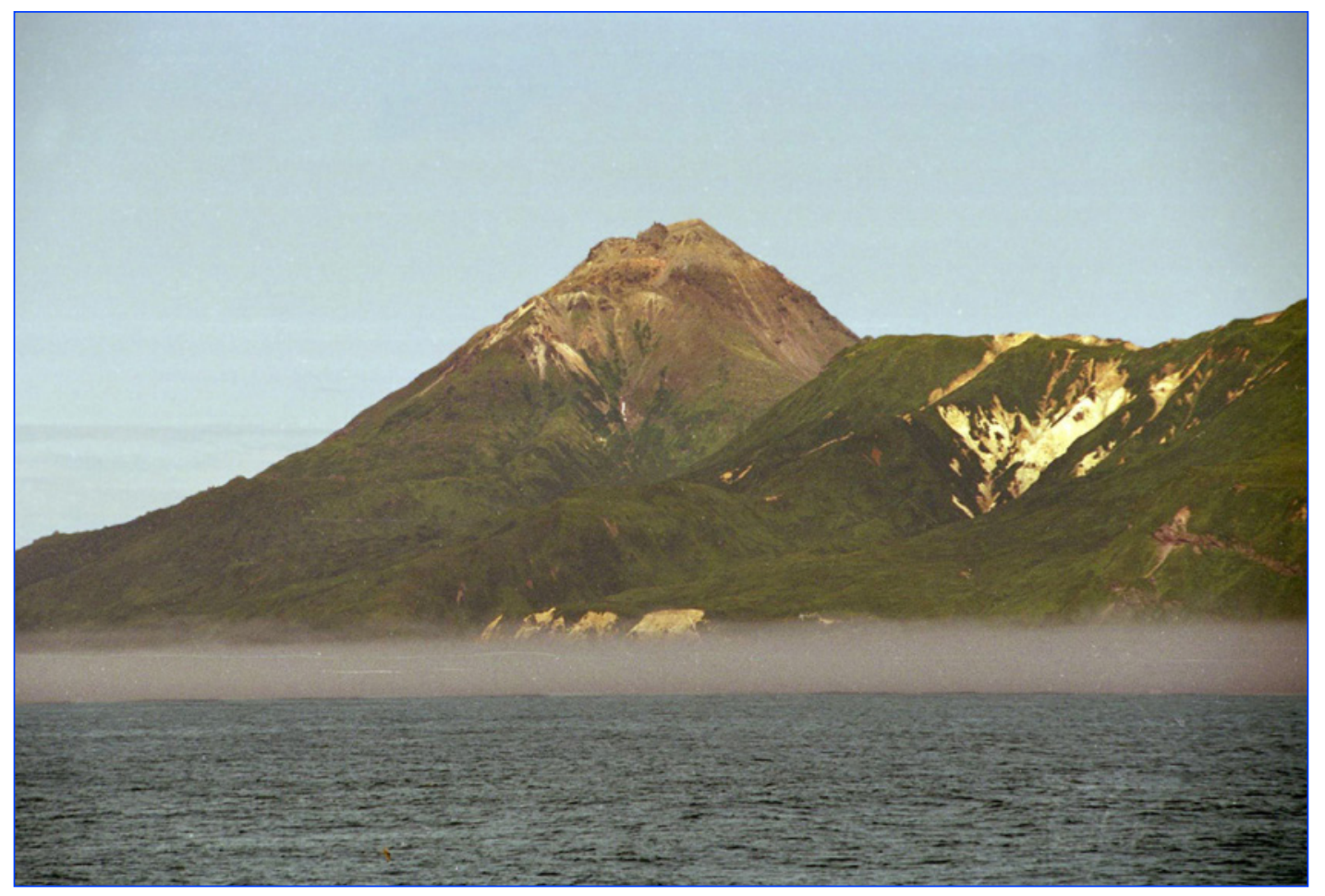

Figure 42. Southeastern flank of Ekarma Volcano. Photograph by A. Rybin, 2008. 


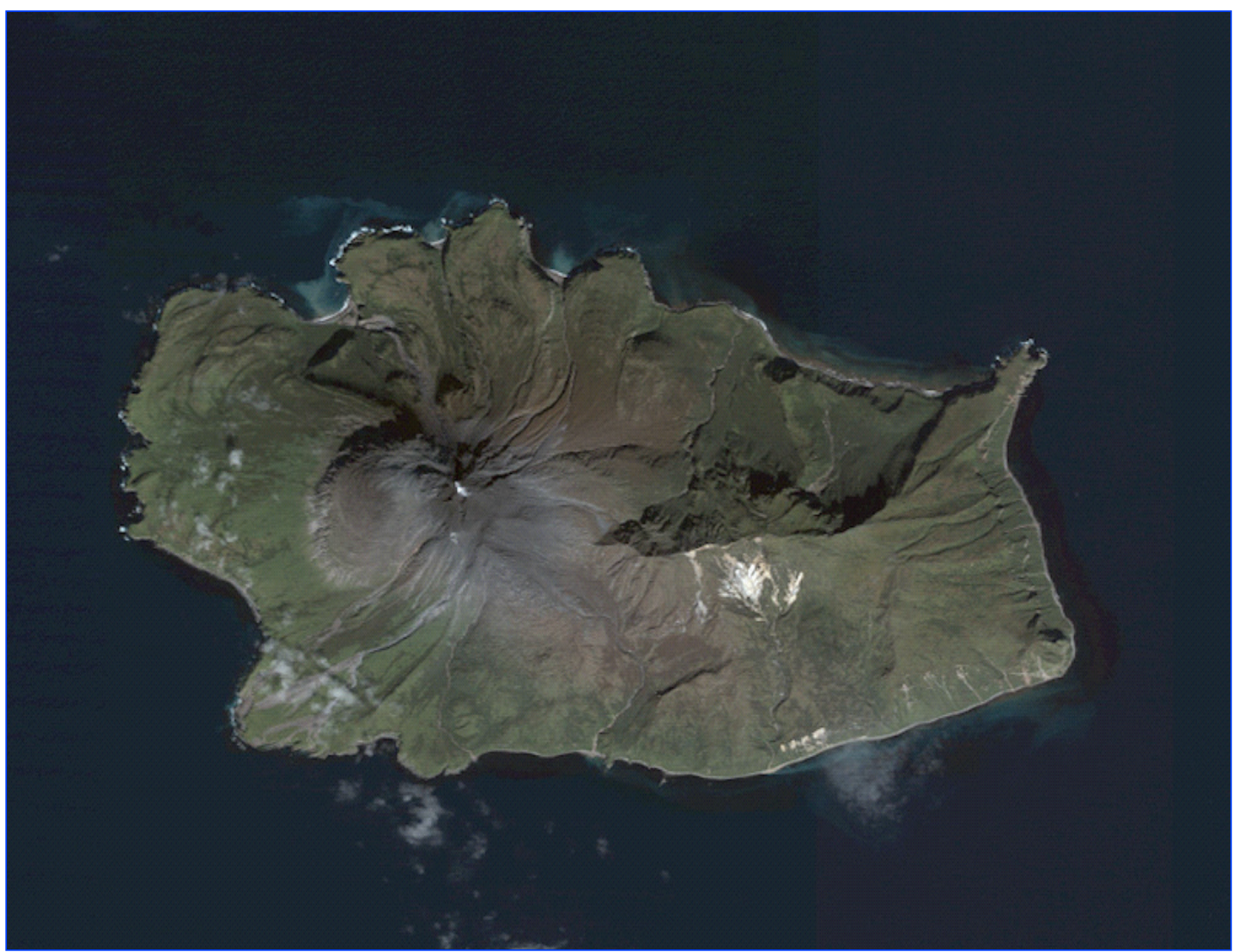

Figure 43. Ekarma Island as seen in an International Space Station image in September 2009. The island is approximately 5 by $7.5 \mathrm{~km}$ (3 by $4.7 \mathrm{mi}$ ). ISS photograph 20.09.2010, courtesy NASA.
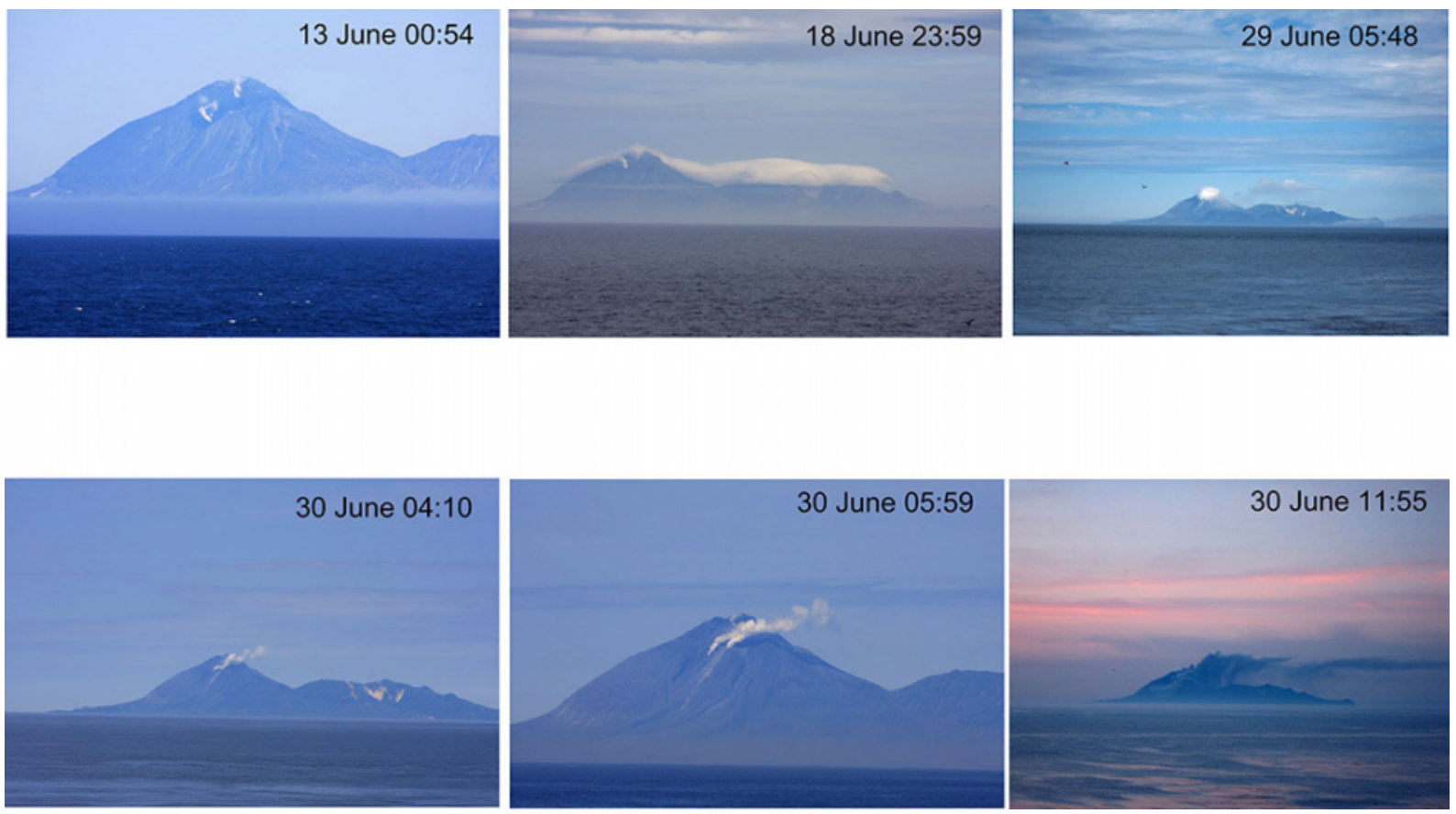

Figure 44. Views of Ekarma Volcano from Skala Dolgaya Island (42 km or 26 mi southwest of Ekarma Island) during June 2010. Time stamps are in UTC. Images courtesy A.S. Neroda, Pacific Institute of Geography FEB RAS. 


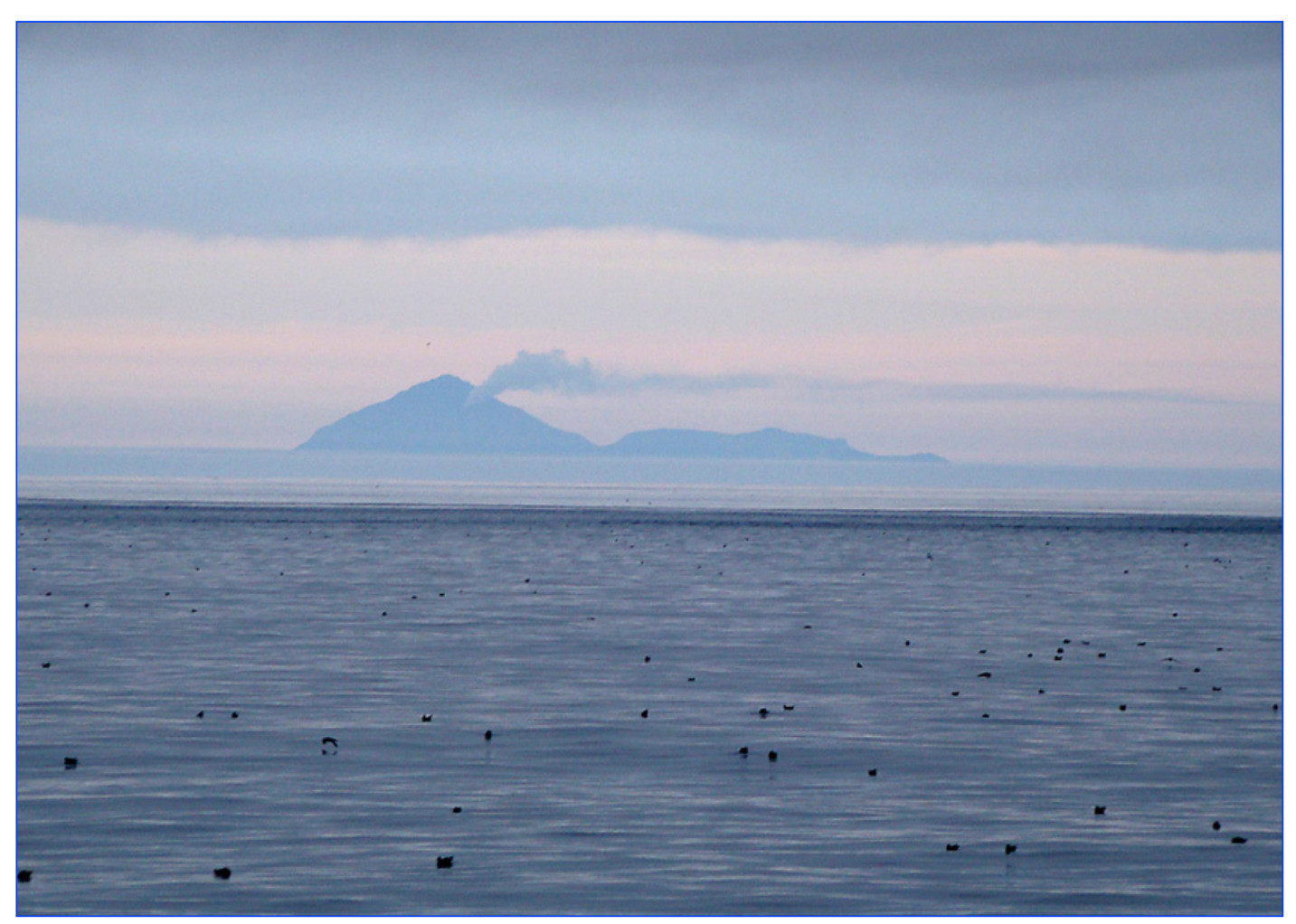

Figure 45. Steam-gas emission from Ekarma Volcano. Photograph by A. Rybin from Raikoke Island $90 \mathrm{~km}$ (55 mi) from Ekarma, August 10, 2010.

On August 24, the expedition went ashore on Ekarma and ascended the volcano to its summit. A new explosion crater was visible near the volcano's summit. A vigorous white vapor plume rose from this feature (fig. 44, panel 1). The surface of the volcano was covered with gray ash varying in thickness and grain size from about 4 to $6 \mathrm{~cm}$ (1.5 to $2.4 \mathrm{in}$.) of finegrained sand (fig. 46D) near the summit at $900 \mathrm{~m}(2,950 \mathrm{ft})$ elevation to about $1-2 \mathrm{~mm}(<1 / 10$ th inch $)$ of finer ash at $300 \mathrm{~m}$ (980 ft) elevation (fig. 46C). In addition to tephra fall deposits, several small lahars had descended the southern flank of the volcano reaching the sea (fig. 46B).

The eruption locally impacted vegetation on Ekarma Island. Between 250 and $300 \mathrm{~m}$ (820 and $980 \mathrm{ft}$ ), plants appeared stressed and at about $550 \mathrm{~m}(1,800 \mathrm{ft})$, most plants showed signs of acidic aerosol burns. Where lahars descended gullies on the southern flank, soil and vegetation were completely buried.

A QuickBird image from September 20, 2010, showed continuing fumarolic activity is only on the central and upper fumarolic sites of the volcano. In addition to lahars on the southern flank of the volcano, lahars also descended the northern flank. Sediment plumes offshore indicated where lahars had reached the sea causing increased input of sediment transported near-shore currents.

A preliminary volume of erupted material is $2 \times 10^{5} \mathrm{~m}^{3}$, making the 2010 eruption a VEI 1 . Examination of ejected material indicates the eruption was phreatic in nature.

The small 5 by $7.5 \mathrm{~km}$ (3 by $4.7 \mathrm{mi}$ ) island of Ekarma lies $8.5 \mathrm{~km}$ (5.2 mi) north of Shiashkotan Island along an east-west-trending volcanic chain extending westward from the central part of the main Kuril Island arc. Ekarma is composed of two overlapping basaltic-andesite to andesitic volcanoes, the western of which has been historically active forming a steep-sided stratovolcano. Lava flows radiate $3 \mathrm{~km}$ (1 mi) in all directions from the summit of the younger cone to the sea, forming a lobate shoreline. A lava dome that was emplaced during the only known pre-2010 historical eruption, in 1776-79, forms the peaked, 1,170-m-high summit of the island. Fumarolic activity was observed during the first half of 19th century; at the beginning and in the middle of 20th century, no fumarolic activity was noted by periodic observers (Gorshkov, 1970). 


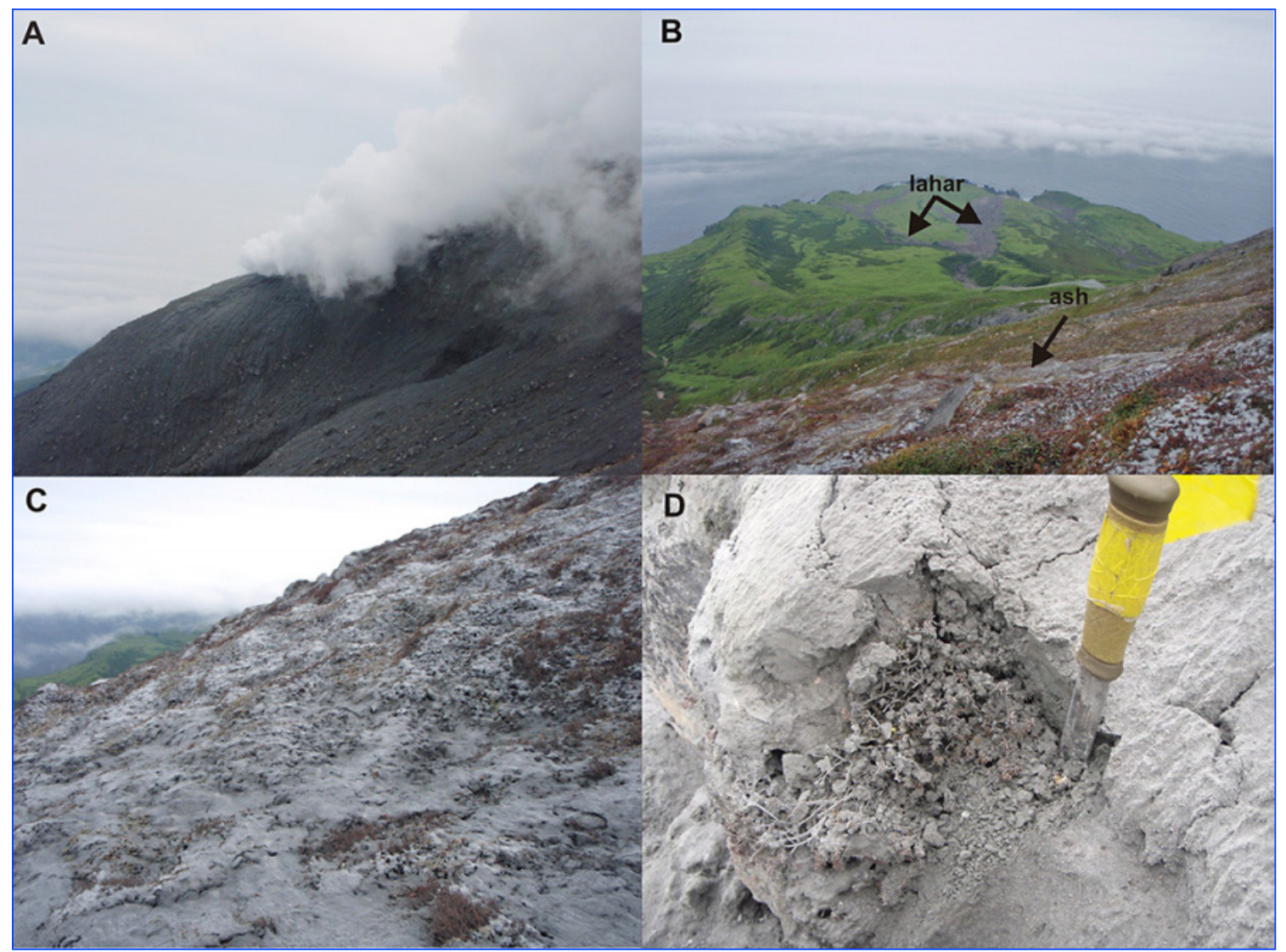

Figure 46. Impacts of the June 2010 eruption of Ekarma. (A) New-formed crater near the summit of the volcano; $(B)$ Lahars on the southern flank of the volcano reaching the sea; ( $C$ ) Ash-covered slopes of the volcano, covered with ash; $(D)$ The thickness of ash is $5 \mathrm{~cm}$ (2 in.). Photographs by E. Kravchunovskaya, taken on August 24, 2010; used with permission. 


\section{Summary}

2010 was a relatively quiet year in terms of eruptions and unrest for the Alaska Volcano Observatory. The sole confirmed eruptive activity occurred at Cleveland volcano in the central Aleutians; other volcanoes in Alaska provided minor unrest in the form of unusual seismicity, fumarolic emissions of note, and suspicious clouds that probably were non-volcanic in origin.

In Russia, ongoing eruptions at the long-active volcanoes Sheveluch, Klyuchevskoy, Bezymianny, and Karymsky were sources of multiple ash clouds and lava effusion. A major explosive eruption began at Kizimen that continued into 2011. In the Kurile Islands, a small phreatic eruption at Ekarma was the only activity of note.

\section{Acknowledgments}

This report represents work of the entire Alaska Volcano Observatory staff, colleagues from other USGS Volcano Observatories, cooperating State and Federal agencies, and members of the public. Russian volcanic activity is documented by many scientists at the Institute of Volcanology and Seismology, the Kamchatkan Branch of Geophysical Surveys, and the Institute of Marine Geology and Geophysics. Careful technical reviews by Cheryl Cameron and Rick Wessels improved the content and presentation. Cheryl Cameron and Seth Snedigar are especially acknowledged for the design and maintenance of the excellent internal log files of the Alaska Volcano Observatory. The authors also wish to thank Sam Friedman for his assistance with early drafts.

\section{References Cited}

Bacon, C.R., Sisson, T.W., and Mazdab, F.K., 2007, Young cumulate complex beneath Veniaminof caldera, Aleutian arc, dated by zircon in erupted plutonic blocks: Geology, v. 35, no. 6, p. 491-494, doi: 10.1130/G23446A.1.

Beget, J.E., Nye, C.J., and Bean, K.W., 2000, Preliminary volcano-hazard assessment for Makushin Volcano, Alaska: Alaska Division of Geological \& Geophysical Surveys Report of Investigations 2000-4, 22 p., 1 sheet, scale 1:100,000.
Belousov, A., and Belousova, M., 2001, Eruptive process, effects and deposits of the 1996 and the ancient basaltic phreatomagmatic eruptions in Karymskoye lake, Kamchatka, Russia, in White, J.D., and Riggs, N.R. eds., Volcaniclastic Sedimentation in Lacustrine Settings: Special Publications of the International Association of Sedimentologists, v. 30, p. 36-60, accessed November 4, 2013, at http://www.kscnet.ru/ivs/lavdi/staff/belousov/lake. pdf.

Benson, Carl, Motyka, Roman, McNutt, Stephen, Luethi, Martin, and Truffer, Martin, 2007, Glacier-volcano interactions in the north crater of Mt. Wrangell, Alaska: Annals of Glaciology, v. 45, p. 48-57.

Bogoyavlenskaya, G.E., Braitseva, O.A., Melekestsev, I.V., Kiriyanov, V. Yu., and Miller, C.D., 1985, Catastrophic eruptions of the directed-blast type at Mount St. Helens, Bezymianny and Shiveluch Volcanoes: Journal of Geodynamics, v. 3, nos. 3-4, p. 189-218.

Bull, K.F, and Buurman, H., 2013, An overview of the 2009 eruption of Redoubt Volcano, Alaska: Journal of Volcanology and Geothermal Research, v. 259, p. 2-15, doi: 10.1016/j.jvolgeores.2012.06.024.

Calvert, A.T., Moore, R.B., and McGimsey, R.G., 2005, Argon geochronology of Late Pleistocene to Holocene Westdahl Volcano, Unimak Island, Alaska, in Haeussler, P.J., and Galloway, J.P., eds., Studies by the U.S. Geological Survey in Alaska, 2004: U.S. Geological Survey Professional Paper 1709-D, 16 p., http://pubs.usgs.gov/pp/pp1709d/.

Cameron, C.E., Nye, C.J., and Neal, C.A., 2008, Counting Alaska Volcanoes [abs.]: American Geophysical Union, Fall Meeting, abstract V43H-07.

Carter A.J., Ramsey, M.S., and Belousov, A.B., 2007, Detection of a new summit crater on Bezymianny Volcano lava dome - satellite and field-based thermal data: Bulletin of Volcanology, v. 69, no. 7, p. 811-815, doi: 10.1007/ s00445-007-0113-x.

Dean, K.G., Engle, K., Groves, J., Dehn, J., and Partington, K., 2002, Analysis of surface processes using SAR data; Westdahl Volcano, Alaska: International Journal of Remote Sensing, v. 23, n. 21, p. 4529-4550.

De Angelis, Silvio, Fee, David, Haney, Matthew, and Schneider, David, 2012, Detecting hidden volcanic explosions from Mt. Cleveland Volcano, Alaska with infrasound and ground-coupled airwaves: Geophysical Research Letters, v. 39, L21312, 6 p., doi: 10.1029/2012GL053635. 
Dean, K.G., Dehn, Jonathan, Papp, K.R., Smith, Steve, Izbekov, Pavel, Peterson, Rorik, Kearney, Courtney, and Steffke, Andrea, 2004, Integrated satellite observations of the 2001 eruption of Mt. Cleveland, Alaska: Journal of Volcanology and Geothermal Research, v. 135, p. 51-73.

DeGange, A.R., Byrd, G.V., Walker, L.R., and Waythomas, C.F., 2010, Introduction - the impacts of the 2008 eruption of Kasatochi Volcano on terrestrial and marine ecosystems in the Aleutian Islands, Alaska: Arctic, Antarctic, and Alpine Research, v. 42, no. 3, p. 245-249, doi: 10.1657/1938-424642.3.245.

Detterman, R.L., Wilson, F.H., Yount, M.E., and Miller, T.P., 1987, Quaternary geologic map of the Ugashik, Bristol Bay, and western part of Karluk quadrangles, Alaska: U.S. Geological Survey Miscellaneous Investigations Series Map 1801, 1 sheet, scale 1:250,000, accessed November 4, 2013, at http://www.dggs.dnr.state.ak.us/pubs/pubs?reqtype=citati on\&ID $=12928$.

Dixon, J.P., Stihler, S.D., Power, J.A., and Searcy, C.K., 2011, Catalog of earthquake hypocenters at Alaskan volcanoesJanuary 1 through December 31, 2010: U.S. Geological Survey Data Series 645, 82 p., http://pubs.usgs.gov/ds/645/.

Dreher, S.T., Eichelberger, J.C., and Larsen, J.F., 2005, The petrology and geochemistry of the Aniakchak calderaforming ignimbrite, Aleutian Arc, Alaska: Journal of Petrology, v. 46, no. 9, p. 1747-1768, doi: 10.1093/ petrology/egi032.

Ewert, J.W., Holzworth, R.H., and Diefenbach, A.K., 2010, Global detection of explosive volcanic eruptions with the World Wide Lightning Location Network (WWLLN) and application to aviation safety [abs.]: American Geophysical Union, Fall Meeting 2010, abstract \#AE31A-04.

Fedotov, S.A., 1998, The 1996 eruption in the Karymsky volcanic center and related events: Special Issue of Volcanology and Seismology, v. 19, no. 5, p. 521-767 (L.N. Rykunov, Editor in Chief, Preface and 10 papers, English translation), Gordon \& Breach Science Publishers (ISBN 0742-0463).

Fee, D., Steffke, A., and Garces, M., 2010, Characterization of the 2008 Kasatochi and Okmok eruptions using remote infrasound arrays: Journal of Geophysical Research, v. 115, D00L10, 15 p., doi:10.1029/2009JD013621.

Gardine, Matt, West, Michael, Werner, Cynthia, and Doukas, Michael, 2011, Evidence of magma intrusion at Fourpeaked volcano, Alaska in 2006-2007 from a rapid-response seismic network and volcanic gases: Journal of Volcanology and Geothermal Research, v. 200, nos. 3-4, p. 192-200, doi: 10.1016/j.jvolgeores.2010.11.018.
Gardner, C.A., and Guffanti, M.C., 2006, U.S. Geological Survey's alert notification system for volcanic activity: U.S. Geological Survey Fact Sheet 2006-3139, 4 p., http://pubs. usgs.gov/fs/2006/3139/.

Girina, O.A., Bogoyavlenskaya, G.E., and Demyanchuk, Yu. V., 1993, Bezymianny eruption of August 2, 1989: Volcanology and Seismology, v. 15, no. 2, p. 135-144.

Girina, O.A., Manevich A.G., and Ushakov S.V., 2010, Activity of Kamchatkan volcanoes in 2010 - Modern volcanism and associated processes: PetropavlovskKamchatsky, Institute of Volcanology and Seismology, Far East Division of the Russian Academy of Sciences (FED RAS), p. 19-24. [in Russian.]

Gorshkov, G.S., 1959, Gigantic eruption of Volcano Bezymianny: Bulletin of Volcanology, v. 20, p.77-109.

Gorshkov, G.S., 1970, Catalog of the active volcanoes of the world including solfatara fields. Part VII. Kurile Islands: International Volcanology Association, Via Tasso 199, Napoli, Italy, 99 p.

Grewingk, Constantine, 1850, Grewingk's geology of Alaska and the Northwest Coast of America [edited by Marvin W. Falk, translation by Fritz Jaensch published 2003]: Rasmuson Library Historical Translation Series 11, Fairbanks, Alaska, The University of Alaska Press, 242 p.

Hadley, David, Hufford, G.L., and Simpson, J.J., 2004, Resuspension of relic volcanic ash and dust from KatmaiStill an aviation hazard: Weather and Forecasting, v. 19, no. 5, p. 829-840.

Hildreth, Wes, and Fierstein, Judy, 2000, Katmai volcanic cluster and the great eruption of 1912: Geological Society of America Bulletin, v. 112, no. 10, p. 1594-1620, 6 sheets, scale unknown.

Hildreth, Wes, Fierstein, Judy, and Calvert, A.T., 2007, Blue Mountain and The Gas Rocks - rear-arc dome clusters on the Alaska Peninsula, in Haeussler, P.J., and Galloway, J.P., eds., Studies by the U.S. Geological Survey in Alaska, 2006: U.S. Geological Survey Professional Paper 1739-A, 27 p., http://pubs.usgs.gov/pp/pp1739/a/.

Ivanov B.V., Chirkov, A.M., Dubik, Yu. M., Gavrilov, V.A., Stepanov, V.V., Rulenko, O.P., and Firstov, P.P., 1981, The state of the volcanoes of Kamchatka and the Kurile Islands in 1980: Volcanology and Seismology, no. 3. p. 99-104.

Ivanov, B.V., Braitseva, O.A., and Zubin, M.I., 1991, Karymsky Volcano, chapter 21, in Fedotov, S.A., and Masurenkov, Yu. P. (eds.), Active volcanoes of Kamchatka: Moscow, Nauka Publishers, v. 2, p. 202-203. 
Ji, Lingyun, Lu, Zhong, Dzurisin, Daniel, and Senyukov, Sergey, 2013, Pre-eruption deformation caused by dike intrusion beneath Kizimen volcano, Kamchatka, Russia, observed by InSAR: Journal of Volcanology and Geothermal Research, v. 256, no. 15, p. 87-95, doi: 10.1016/j.jvolgeores.2013.02.011.

Khrenov, A.P., Dvigalo, V.N., Kirsanov, I.T., Fedotov, S.A., Gorel'chik, I., and Zharinov, N.A., 1991, Klyuchevskoy Volcano, chapter 6, in Fedotov, S.A., and Masurenkov, Yu. P. eds., Active volcanoes of Kamchatka: Moscow, Nauka Publishers, v. 1, p. 146-163.

Kienle, Juergen, Kyle, P.R., Self, Stephen, Motyka, R.J., and Lorenz, Volker, 1980, Ukinrek Maars, Alaska-I, April 1977 eruption sequence, petrology and tectonic setting: Journal of Volcanology and Geothermal Research, v. 7, no. 1, p. 11-37.

Kirsanova, T.P., Vergasova, L.P., Yurova, L.M., and Taran, Yu. A., 1983, Fumarole activity of Sheveluch and Kizimen volcanoes in 1979-1980: Volcanology and Seismology, no. 3, p. 33-42.

Levin, B.V., Fitzhugh, B., and Bourgeois, D., 2009, Complex expedition in the Kurile Island in 2008 (III stage): Vestnik of Far East Branch of Russian Academy of Sciences, no. 2, p. 134-142.

Lu, Zhong, 2007, InSAR imaging of volcanic deformation over cloud-prone areas-Aleutian Islands: Photographgrammetric Engineering and Remote Sensing, v. 73, no. 3, p. 245-257.

Lu, Zhong, Masterlark, Timothy, Dzurisin, Daniel, Rykhus, Russel, and Wicks, Charles, Jr., 2003, Magma supply dynamics at Westdahl volcano, Alaska, modeled from satellite radar interferometry: Journal of Geophysical Research, v. 108, no. B7, 2354, 17 p., doi: 10.1029/2002JB002311.

Lu, Zhong, Wicks, Charles, Jr., Dzurisin, Daniel, Power, J.A., Moran, S.C., and Thatcher, Wayne, 2002, Magmatic inflation at a dormant stratovolcano-1996-1998 activity at Mount Peulik volcano, revealed by satellite radar interferometry: Journal of Geophysical Research, v. 107, no. B7, p. 4-13, doi: 10.1029/2001JB000471.

McConnell, V.S., Beget, J.E., Roach, A.L., Bean, K.W., and Nye, C.J., 1998, Geologic map of the Makushin volcanic field, Unalaska Island, Alaska: Alaska Division of Geological \& Geophysical Surveys Report of Investigations 97-20, 2 sheets, scale 1:63,360.

McGimsey, R.G., and Neal, C.A., 1996, 1995 Volcanic activity in Alaska and Kamchatka - Summary of events and response of the Alaska Volcano Observatory: U.S. Geological Survey Open-File Report 96-738, 23 p., http:// pubs.er.usgs.gov/publication/ofr96738.
McGimsey, R.G., Neal, C.A., Dixon, J.P., Malik, Nataliya, and Chibisova, Marina, 2011, 2007 Volcanic activity in Alaska, Kamchatka, and the Kurile Islands: Summary of events and response of the Alaska Volcano Observatory: U.S. Geological Survey Scientific Investigations Report 20105242, 110 p., http://pubs.usgs.gov/sir/2010/5242/.

McGimsey, R.G., Neal, C.A., Dixon, J.P., and Ushakov, Sergey, 2007, 2005 Volcanic activity in Alaska, Kamchatka, and the Kurile Islands: Summary of events and response of the Alaska Volcano Observatory: U.S. Geological Survey Scientific Investigations Report 2007-5269, 94 p., http:// pubs.usgs.gov/sir/2007/5269/.

McGimsey, R.G., Neal, C.A., and Girina, Olga, 2003, 1998 Volcanic activity in Alaska and Kamchatka: Summary of events and response of the Alaska Volcano Observatory: U.S. Geological Survey Open-File Report 03-0423, 35 p., http://pubs.usgs.gov/of/2003/of03-423/.

McGimsey, R.G., Neal, C.A., Girina, O.A., Chibisova, Marina, and Rybin, Alexander, 2013, 2009 Volcanic activity in Alaska, Kamchatka, and the Kurile Islands: Summary of events and response of the Alaska Volcano Observatory: U.S. Geological Survey Scientific Investigations Report 2013-5213, 125 p., http://pubs.usgs.gov/sir/2013/5213/.

McGimsey, R.G., and Wallace, K.L., 1999, 1997 Volcanic activity in Alaska and Kamchatka-Summary of events and response of the Alaska Volcano Observatory: U.S. Geological Survey Open-File Report 99-448, 42 p., http:// pubs.er.usgs.gov/publication/ofr99448.

Melekestsev, I.V., Ponomareva, V.V., and Volynets, O.N., 1995, Kizimen volcano (Kamchatka)—future Mt. St. Helens?: Journal of Volcanology and Geothermal Research, v. 65, p. 205-226, accessed July 6, 2013, at http://www. kscnet.ru/ivs/bibl/vulk/kiz/jvgr kizimen.pdf.

Melekestsev, I.V., Volynets, O.N., Yermakov, V.A., Kirsanova, T.P., and Masurenkov, Y.P., 1991, Sheveluch VolcanoActive volcanoes of Kamchatka: Moscow, Nauka Publishers, v. 1, p. 84-103.

Miller, T.P., and Chouet, B.A., 1994, The 1989-1990 eruptions of Redoubt volcano - an introduction, in Miller, T.P., and Chouet, B.A., eds., The 1989-1990 eruptions of Redoubt Volcano, Alaska: Journal of Volcanology and Geothermal Research, v. 62, no. 1, p. 1-10.

Miller, T.P., McGimsey, R.G., Richter, D.H., Riehle, J.R., Nye, C.J., Yount, M.E., and Dumoulin, J.A., 1998, Catalog of the historically active volcanoes of Alaska: U.S. Geological Survey Open-File Report 98-582, 104 p., http://pubs.er.usgs. gov/publication/ofr98582.

Miller, T.P., and Smith, R.L., 1987, Late Quaternary calderaforming eruptions in the eastern Aleutian arc, Alaska: Geology, v. 15, no. 5, p. 434-438. 
National Marine Fisheries Service, 2014, Commercial fisheries statistics: Website, accessed April 15, 2014, at https://www. st.nmfs.noaa.gov/commercial-fisheries/index.

Neal, C.A., Doukas, M.P., and McGimsey, R.G., 1995, 1994 Volcanic activity in Alaska - Summary of events and response of the Alaska Volcano Observatory: U.S. Geological Survey Open-File Report 95-271, 19 p., http:// pubs.er.usgs.gov/publication/ofr95271.

Neal, Christina, Girina, Olga, Senyukov, Sergey, Rybin, Alexander, Osiensky, Jeffrey, Izbekov, Pavel, and Ferguson, Gail, 2009a, Russian eruption warning systems for aviation: Natural Hazards, v. 50, no. 2, p. 245-262, doi: 10.1007/ s11069-009-9347-6.

Neal, C.A., and McGimsey, R.G., 1997, 1996 Volcanic activity in Alaska and Kamchatka-Summary of events and response of the Alaska Volcano Observatory: U.S. Geological Survey Open-File Report 97-433, 34 p., http:// pubs.er.usgs.gov/publication/ofr97433.

Neal, C.A., McGimsey, R.G., Dixon, J.P., Manevich, Alexander, and Rybin, Alexander, 2009b, 2006 Volcanic Activity in Alaska, Kamchatka, and the Kurile Islands - Summary of events and response of the Alaska Volcano Observatory: U.S. Geological Survey Scientific Investigations Report 2008-5214, 102 p., http://pubs.usgs. gov/sir/2008/5214/.

Neal, C.A., McGimsey, R.G., and Doukas, M.P., 1996, 1993 Volcanic activity in Alaska-Summary of events and response of the Alaska Volcano Observatory: U.S. Geological Survey Open-File Report 96-24, 21 p., http:// pubs.er.usgs.gov/publication/ofr9624.

Neal, Christina, McGimsey, R.G., Miller, T.P., Riehle, J.R., and Waythomas, C.F., 2000, Preliminary volcano-hazard assessment for Aniakchak Volcano, Alaska: U.S. Geological Survey Open-File Report 00-0519, 35 p., http://pubs.er.usgs. gov/publication/ofr00519.

Neal, Christina, Rybin, Alexander, Chibisova, Marina, and Miller, Edward, 2008, Active volcanoes of the Kurile Islands-A reference guide for aviation users: U.S. Geological Survey Open-File Report 2008-1162, 10 p., http://pubs.er.usgs.gov/publication/ofr20081162.

Neal, C.A., McGimsey, R.G., Dixon, J.P., and Melnikov, Dmitry, 2005, 2004 Volcanic activity in Alaska and Kamchatka: Summary of events and response of the Alaska Volcano Observatory: U.S. Geological Survey Open File Report 2005-1308, 71 p.
McGimsey, R.G., Neal, C.A., Dixon, J.P., and Ushakov, Sergey, 2007, 2005 Volcanic activity in Alaska, Kamchatka, and the Kurile Islands: Summary of events and response of the Alaska Volcano Observatory: U.S. Geological Survey Scientific Investigations Report 2007-5269, 94 p., http:// pubs.usgs.gov/sir/2007/5269/.

Nicholson, R.S., Gardner, J.E., and Neal, C.A., 2011, Variations in eruption style during the 1931 A.D. eruption of Aniakchak volcano, Alaska: Journal of Volcanology and Geothermal Research, v. 207, nos. 3-4, p. 69-82, doi:10.1016/j.jvolgeores.2011.08.002.

Ovsyannikov A.A., and Chirkov S.A., 2010, The state of Gorely volcano in June 2010: Vestnik KRAUNTS, Nauki o Zemle, v. 1, no.15, p. 10. [in Russian.]

Piip, B.I., 1946, Kizimen Volcano: Bulletin of Volcanology, Stat. at Kamchatka, no. 13, p. 22-32. [in Russian.]

Ponomareva, V.V., Pevzner, M.M., and Melekestsev, I.V., 1998, Large debris avalanches and associated eruptions in the Holocene eruptive history of Shiveluch Volcano, Kamchatka, Russia: Bulletin of Volcanology, v. 59, no. 7, p. 490-505.

Ramsey, M.S., Wessels, R.L., and Anderson, S.W., 2012, Surface textures and dynamics of the 2005 lava dome at Shiveluch volcano, Kamchatka: Geological Society of America Bulletin, v. 124, nos. 5-6, p. 678-689, doi: 10.1130/B30580.1.

Richter, D.H., Rosenkrans, D.S., and Steigerwald, M.J., 1995, Guide to the volcanoes of the western Wrangell Mountains, Alaska; Wrangell-St. Elias National Park and Preserve: U.S. Geological Survey Bulletin 2072, 31 p., http://pubs.er.usgs. gov/publication/b2072.

Rybin, A., Chibisova, M., Webley, P. Steensen, T. Izbekov, P. Neal, C., and Realmuto, V., 2011, Satellite and ground observations of the June 2009 eruption of Sarychev Peak Volcano, Matua Island, Central Kuriles: Bulletin of Volcanology, vol. 73, iss. 9 (November 2011), p. 13771392.

Schaefer, J.R., ed., 2012, The 2009 Eruption of Redoubt Volcano, Alaska, with contributions by Bull, K.F., Cameron, C.E., Coombs, M.L., Diefenbach, A.K., Lopez, T., McNutt, S.R., Neal C.A., Payne A.L., Power, J.A., Schneider, D.J., Scott, W.E., Snedigar, S.F., Thompson, G., Wallace, K.L., Waythomas, C.F., Webley, P.W., and Werner, C.A.: Alaska Division of Geological and Geophysical Surveys Report of Investigations 2011-5, 45 p., accessed July 5, 2013, at http:// www.dggs.alaska.gov/pubs/id/23123. 
Scott, W.E., Nye, C.J., Waythomas, C.F., and Neal, C.A., 2010, August 2008 eruption of Kasatochi Volcano, Aleutian Islands, Alaska - resetting an island landscape: Arctic, Antarctic, and Alpine Research, v. 42, no. 3, p. 250-259, doi:10.1657/1938-4246-42.3.250.

Siebert, Lee, Simkin, Tom, and Kimberly, Paul, 2010, Volcanoes of the World (3d ed.): Berkley, Calif., University of California Press, 568 p.

Symonds, R.B., Ritchie, B.E., McGimsey, R.G., Ort, M.H., Poreda, R.J., Evans, W.C., and Janik, C.J., 1997, Investigations of gas seep and spring sampling in the vicinity of Gas Rocks, South Shore Becharof Lake: U.S. Geological Survey Open-File Report 97-127, 27 p., http:// pubs.er.usgs.gov/publication/ofr97127.

Waythomas, C.F., Dorava, J.M., Miller, T.P., Neal, C.A., and McGimsey, R.G., 1997, Preliminary volcano-hazard assessment for Redoubt Volcano, Alaska: U.S. Geological Survey Open-File Report 97-857, 40 p., 1 plate, http://pubs. er.usgs.gov/publication/ofr97857.
Waythomas, C.F., Scott, W.E., and Nye, C.J., 2010, The geomorphology of an Aleutian volcano following a major eruption - the 7-8 August 2008 eruption of Kasatochi Volcano, Alaska, and its aftermath: Arctic, Antarctic, and Alpine Research, v. 42, no. 3, p. 260-275, doi:10.1657/1938-4246-42.3.260.

Werner, Cynthia, Kelly, P., Doukas, M., Lopez, T., Pfeffer, M., McGimsey, R., and Neal, C., 2012, Degassing of $\mathrm{CO}_{2}, \mathrm{SO}_{2}$, and $\mathrm{H}_{2} \mathrm{~S}$ associated with the 2009 eruption of Redoubt Volcano, Alaska: Journal of Volcanology and Geothermal Research, v. 259, p. 270-284, doi:10.1016/j. jvolgeores.2012.04.012.

Zharinov, N.A., Bogoyavlenskaya, G.E., Khubunaya, S.A., and Demyanchuk Yu. V., 1995, A new eruption cycle of Shiveluch Volcano, 1980-1993: Volcanology and Seismology, v. 17, p. 21-30. [in Russian.] 
722010 Volcanic Activity in Alaska, Kamchatka, and the Kurile Islands-Summary of Events and Response of the AVO

This page intentionally left blank. 


\section{Glossary of Selected Terms and Acronyms}

ADGGS Alaska Division of Geological \& Geophysical Surveys.

AKDT “Alaska Daylight Time”; UTC -8 hours.

AKST “Alaska Standard Time”; UTC -9 hours.

andesite volcanic rock composed of about 53-63 percent silica ( $\mathrm{SiO} 2$, an essential constituent of most minerals found in rocks).

ash fine fragments (less than 2 millimeters across) of lava or rock formed in an explosive volcanic eruption.

ASL above sea level.

ASTER Advanced Spaceborne Thermal Emission and Reflection Radiometer.

AVHRR "Advanced Very High Resolution Radiometer”; AVHRR provides one form of satellite imagery.

AVO Alaska Volcano Observatory.

basalt general term for dark-colored igneous rock, usually extrusive, containing about 45-52 weight percent silica ( $\mathrm{SiO} 2$, an essential constituent of most minerals found in rocks).

bomb boulder-size chunk of partly solidified lava explosively ejected from a volcano.

caldera a large, roughly circular depression usually caused by volcanic collapse or explosion.

CAVW Smithsonian Institute's "Catalog of Active Volcanoes of the World" (Siebert and others, 2010)

cinder cone small, steep-sided conical hill built mainly of cinder, spatter, and volcanic bombs.

COSPEC “Correlation Spectrometer," a device for optically and remotely measuring sulfur-dioxide emissions.

ERSDAC Earth Remote Sensing Data Analysis Center.

FAA Federal Aviation Administration.

fallout a general term for debris which falls to the Earth from an eruption cloud. fault A fracture along which the blocks of the Earth's crust on either side have moved relative to one another parallel to the fracture.

fissure a roughly linear or sinuous crack or opening on a volcano; a type of vent which commonly produces lava fountains and flows.

FLIR "Forward Looking Infrared

Radiometer," used to delineate objects of different temperature.

F/V Fishing Vessel.

fumarole a small opening or vent from which hot gases are emitted.

GMS Geostationary Meteorological Satellite.

GMT Greenwich Mean Time.

GOES Geostationary Operational Environmental Satellite.

GPS Global Positioning System.

GSFC Goddard Space Flight Center.

Holocene geologic epoch extending from the present to 10,000 years ago.

HRPT High Resolution Picture Transmission

IMGG Russian "Institute of Marine Geology and Geophysics."

InSAR Interferometric Synthetic Aperture Radar.

intracaldera refers to something within the caldera.

ISS International Space Station.

IVS Russian "Institute of Volcanology and Seismology."

JAROS Japan Resources Observation System Organization.

JMA Japanese Meteorological Agency.

Ka thousands of years before the present.

KDT “Kamchatkan Daylight Time” equals AKDT + 21 hrs.

KBGS Kamchatka Branch of Geophysical Surveys.

KEMSD Russian "Kamchatka Experimental and Methodical Seismological Department." 
KST “Kamchatka Standard Time” equals AST +21 hours.

KVERT Kamchatkan Volcanic Eruption Response Team.

lapilli pyroclasts or volcanic fragments that are between $2 \mathrm{~mm}$ and $64 \mathrm{~mm}$ in diameter.

lava molten rock that has reached the Earth's surface.

magma molten rock below the surface of the Earth.

METI Japanese Ministry of Economy, Trade, and Industry.

MODIS Satellite-based "Moderate-resolution Imaging Spectroradiometer."

NASA National Aeronautics and Space Administration.

NOAA National Oceanic and Atmospheric Administration.

NWS National Weather Service.

OMI Ozone Mapping Instrument on NASA's Aura satellite.

phreatic activity an explosive eruption caused by the sudden heating of ground water as it comes in contact with hot volcanic rock or magma leading to a steam-driven explosion.

phreatic ash fine fragments of volcanic rock expelled during phreatic activity; this ash usually is derived from existing rock and not from new magma.

PIREP “Pilot Weather Report”; a report of meteorological phenomena encountered by aircraft in flight.

pixel contraction of "picture element." A pixel is one of the many discrete rectangular elements that form a digital image or picture on a computer monitor or stored in memory. In a satellite image, resolution describes the size of a pixel in relation to area covered on the ground. More pixels per unit area on the ground means a higher resolution.

Pleistocene geologic epoch extending from about 2.6 million years ago to approximately 10,000 years before present.

PUFF a volcanic ash tracking model.

pyroclast an individual particle ejected during a volcanic eruption; usually classified by size, for example, ash, lapilli.

RSAM Real-time Seismic Amplitude Measurement. regional earthquake earthquake generated by fracture or slippage along a fault; not caused by volcanic activity.

SAR Synthetic Aperture Radar.

satellite cone a subsidiary volcanic vent located on the flank of a larger volcano.

seismic swarm a flurry of closely spaced earthquakes or other ground shaking activity; often precedes an eruption.

shield volcano a broad, gently sloping volcano usually composed of fluid, lava flows of basalt composition (for example, Mauna Loa, Hawaii).

SI International System of Units.

SIGMET SIGnificant METeorological information statement, issued by NWS.

Stratovolcano Also called a stratocone or composite cone, a steep-sided volcano, usually conical in shape, built of interbedded lava flows and fragmental deposits from explosive eruptions.

Strombolian type of volcanic eruption characterized by intermittent bursts of fluid lava, usually basalt, from a vent or crater as gas bubbles rise through a conduit and burst at the surface.

SVA Suspect Volcanic Activity.

SVERT "Sakhalin Volcanic Eruption Response Team" monitors and reports on Kurile Island volcanoes.

SWIR Short Wave Infrared.

tephra a general term covering all fragmental material expelled from a volcano (ash, bombs, cinders, etc.).

TFR “Temporary Flight Restriction,” issued by FAA.

TIR Thermal Infrared.

UAFGI University of Alaska Fairbanks Geophysical Institute.

UFWS United States Fish and Wildlife Service.

USGS United States Geological Survey.

UTC "Coordinated Universal Time"; same as Greenwich Mean Time (GMT).

UUA Urgent pilot report.

VAAC Volcanic Ash Advisory Center

VAA Volcanic Ash Advisory. 
vent an opening in the earth's surface through which magma erupts or volcanic gasses are emitted.

VNIR Very Near Infrared.

volcano-tectonic earthquakes earthquakes generated within or near a volcano from brittle rock failure resulting from strain induced by volcanic processes.

VT volcano-tectonic
Vulcanian style of explosive eruption consisting of repeated, violent ejection of incandescent fragments of viscous lava, usually in the form of blocks, along with volcanic ash. Sometimes, Vulcanian eruptions involve water mixing with erupting magma. 


\section{Appendix 1. Volcano Alert Levels and Aviation Color Codes Used by United States Volcano Observatories, KVERT, and SVERT}

Russian volcano reporting authorities adopted the Aviation Color Codes from the 2006 version of the U.S. system in 2009; KVERT and SVERT do not use the Alert level portion of the scheme.

Alert levels address the overall activity at the volcano, not just the hazard to aviation. There may be situations where a volcano is producing lava flows that are dangerous on the ground and merit a WATCH or WARNING, however, the hazard to aviation is minimal. Alert levels announcements contain additional explanation of volcanic activity and expected hazards where possible. (Gardner and Guffanti, 2006).

\begin{tabular}{|c|l|}
\hline \multicolumn{2}{|c|}{ Alert Levels } \\
\hline NORMAL & $\begin{array}{l}\text { Typical background activity of a volcano in a non-eruptive state. } \\
\text { Or, after a change from a higher level: } \\
\text { Volcanic activity considered to have ceased and volcano reverted to its normal, non-eruptive state }\end{array}$ \\
\hline ADVISORY & $\begin{array}{l}\text { Elevated unrest above known background activity. } \\
\text { Or, after a change from a higher level: } \\
\text { Volcanic activity has decreased significantly but continues to be closely monitored for possible renewed increase. }\end{array}$ \\
\hline WATCH & $\begin{array}{l}\text { Volcano is exhibiting heightened or escalating unrest with increased potential for eruptive activity. } \\
\text { Or: } \\
\text { A minor eruption is underway that poses limited hazards. }\end{array}$ \\
\hline WARNING & Highly hazardous eruption underway or imminent. \\
\hline
\end{tabular}

\begin{tabular}{|c|c|}
\hline \multicolumn{2}{|r|}{ Level of Concern Codes for Aviation } \\
\hline GREEN & $\begin{array}{l}\text { Volcano is in a normal, non-eruptive state. } \\
\text { Or, after a change from a higher level: } \\
\text { Volcanic activity considered to have ceased and volcano reverted to its normal, non-eruptive state }\end{array}$ \\
\hline YELLOW & $\begin{array}{l}\text { Volcano is exhibiting signs of elevated unrest above known background levels. } \\
\text { Or, after a change from a higher level: } \\
\text { Volcanic activity has decreased significantly but continues to be closely monitored for possible renewed increase. }\end{array}$ \\
\hline ORANGE & $\begin{array}{l}\text { Volcano is exhibiting heightened unrest with increased likelihood of eruption. } \\
\text { Or: } \\
\text { Volcanic eruption underway with no or minor ash emission. }\end{array}$ \\
\hline RED & $\begin{array}{l}\text { Eruption is forecast to be imminent with significant emission of ash into the atmosphere likely. } \\
\text { Or: } \\
\text { Eruption is underway with significant emission of ash into the atmosphere. }\end{array}$ \\
\hline
\end{tabular}


Publishing support provided by the U.S. Geological Survey Publishing Network, Tacoma Publishing Service Center

For more information concerning the research in this report, contact the Director, Volcano Science Center

U.S. Geological Survey

4230 University Drive

Anchorage, Alaska 99508

http://volcanoes.usgs.gov/ 
웅

ํํㄹ

吝.

छ.

a

思 